\title{
The Economic Consequences of the Spanish Reconquest: The Long-term Effects of Medieval Conquest and Colonization
}

\author{
DANIEL OTO-PERALÍAS AND DIEGO ROMERO-ÁVILA
}

St Andrews University, Pablo de Olavide University

\begin{abstract}
This paper shows that a historical process that ended more than five centuries ago, the Reconquest, is very important to explain Spanish regional economic development down to the present day. An indicator measuring the rate of Reconquest reveals a heavily negative effect on current income differences across the Spanish provinces. A main intervening factor in the impact the Reconquest has had is the concentration of economic and political power in a few hands, excluding large segments of the population from access to economic opportunities when Spain entered the industrialization phase. The timing of the effect is consistent with this argument. A general implication of our analysis is that large frontier expansions may favor a political equilibrium among the colonizing agents that is biased toward the elite, creating the conditions for an inegalitarian society, with negative consequences for long-term economic development.
\end{abstract}

Keywords: Economic Development, Political Power, Structural inequality, Spanish Reconquest, History

JEL Classification: C21, N2, O1

Corresponding Author: Diego Romero-Ávila, Universidad Pablo de Olavide, Departamento de Economía, Métodos Cuantitativos e Historia Económica, Carretera de Utrera, Km. 1, Sevilla, Spain. E-mail: dromtor@upo.es. Tel. (+34) 954 348 381. Fax: (+34) 954349339.

Daniel Oto-Peralías. University of St Andrews, School of Management, Centre for Responsible Banking \& Finance. The Gateway, North Haugh, St Andrews, Fife, KY16 9AJ, UK. E-mail: dop2@st-andrews.ac.uk.

Acknowledgements: A previous version of this article was presented at the 2014 American Economic Association Meeting held in Philadelphia (January 2014) and at the EH Clio Lab UC Second Annual Conference held in Santiago de Chile (August 2014). The authors are particularly indebted to Oded Galor (the Editor) and the anonymous referees of this Journal for valuable comments and suggestions that led to a substantial improvement of the original manuscript. We also thank Marcella Alsan and James Fenske for detailed comments on an earlier version of this article. Thanks also go to participants at the 2014 AEA meeting, EH Clio Lab UC Second Annual Conference, 2016 Royal Economic Society Annual Conference, and seminars at Pablo de Olavide University, Malaga University and Vienna University of Economics and Business for their valuable comments and suggestions. The authors are indebted to Joan R. Rosés, Julio Martínez-Galarraga and Daniel A. Tirado for sharing with us province-level data on GDP, and industrial and agricultural output in 1860 and 1930. Thanks also go to archival staff of the Provincial Historic Archive of Seville for helping us with the access to some of the data employed in this research program. The authors acknowledge financial support from the Spanish Ministry of Science and Technology (grant ECO2009-13357), the Spanish Ministry of Economics and Competitiveness (grant ECO2012-35430), and the Andalusian Council for Innovation and Science (Excellence Project SEJ-4546). 
"The history of no other European people has been so decisively modified by a frontier as Castile, for century after century"

-Claudio Sánchez-Albornoz, in Burns (1989, p. 325).

\section{Introduction}

This paper shows that the legacy of history is particularly pervasive in Spain. We provide evidence to show that a historical process that ended more than five centuries ago, the Reconquest, is very important to explain Spanish regional economic development. The socalled Reconquista is a milestone in Spanish history. For a period of almost eight hundred years that started in 711 with the invasion of the Iberian Peninsula by the Muslims, what is now mainland Spain experienced a process fairly akin to colonialism. Throughout this long period, and after an initial phase of mere resistance, the Christians located in the North gradually reconquered the Muslim lands and implemented measures to colonize the reclaimed territory. We argue that the rate or speed of the Reconquest, that is, whether the Christian frontier advanced rapidly or not, was a crucial factor affecting the type of colonization conducted in each territory and its corresponding initial political equilibrium. A fast rate of Reconquest is associated with imperfect colonization, characterized by an oligarchic political equilibrium, thus creating the conditions for an inegalitarian society with negative consequences for long-term economic development.

This paper is framed within a new stream of literature dealing with the long-term effects of frontier expansions. In a recent contribution, García-Jimeno and Robinson (2011) have proposed the "conditional frontier hypothesis" to explain the starkly contrasting outcomes derived from the frontier experiences in North America (Turner, 1920) and Latin America (Hennessy, 1978). According to this hypothesis, the consequences of the frontier depend on the initial political equilibrium existing in society at the time of the territorial expansion. In North America, where the prevailing social climate was relatively democratic and egalitarian, the frontier brought about individualism, self-government and aversion to social stratification, whereas in the more oligarchic societies of South America, the presence of a frontier reinforced economic and political inequality. Focusing on the historical border between Castile and the Nasrid Kingdom of Granada in southern Spain, Oto-Peralías and Romero-Ávila (2016) suggest that military insecurity is a factor that favors a political equilibrium biased toward the military elite in frontier regions, generating highly persistent differences in inequality. 
This article introduces and tests the hypothesis that the political equilibrium among the colonizing agents may be endogenous to the scale of frontier expansion. This is because large territorial expansion allows the elite to play a dominant role in the process of colonizing the conquered lands. Applied to our case study, this became evident after the collapse of the Almohad Caliphate in 1212 following the Battle of Las Navas de Tolosa, which enabled the Christian armies to conquer vast swathes of territory in a short period of time. The outcome involved large frontier regions dominated by military orders and the nobility, with negative consequences for long-term development. In contrast, a slow frontier expansion was associated with a more balanced occupation of the territory and a more egalitarian social structure. This was so because smaller frontier regions favored the participation of individual settlers and the Crown in the repopulation, which would lead to better political institutions and a more equitable distribution of the land - as happened in the colonization of the Duero Valley, where settlers occupied land and obtained its ownership. As argued below, these initial differences in the patterns of distribution of economic and political power persisted over time, and led to divergent development paths across what are now the Spanish provinces.

In the empirical part of the paper, we create an indicator measuring the "rate of Reconquest", which captures whether the Christian military conquests progressed rapidly or slowly when each province was reclaimed. We show that there is a robustly negative relationship between the rate of Reconquest and current per capita income across today's Spanish provinces. This relationship does not simply reflect the fact that regions in the South are poorer, since the results survive the inclusion of latitude and many other geographic, topographic and climatic controls. The effect remains statistically significant when the regression analysis is extended to the level of municipality, even after controlling for province fixed effects. The results are not driven by a selection problem informed by the possibility that -for instance- the Christian kingdoms chose to conquer faster economically less attractive territories. A number of falsification tests show that there is no link between the rate of Reconquest and several indicators of pre-Reconquest economic development.

We also analyze the channels through which the rate of Reconquest has affected current income. The results suggest that structural inequality, caused by a high concentration of land and political power in the hands of the nobility, played a central role as intervening variable. This is consistent with the hypothesis formulated by Engerman and Sokoloff $(2000,2002)$ and Acemoglu, Johnson and Robinson -AJR- (2002), whereby a high concentration of economic and political power in a few hands has impaired modern economic growth because it precludes large segments of the population from participating in economic 
activity when the opportunity to industrialize arrived. The timing of the effect of the Reconquest is consistent with this hypothesis, since its negative effect became most apparent during the industrialization period. This interpretation is also congruent with the fact that at the onset of industrialization in Spain (around 1860) the negative impact of the rate of Reconquest was also present in some of the foundations of modern economic growth, such as human capital. A general conclusion of our analysis is that accelerated (and imperfect) colonization may create the conditions for an inegalitarian society, with negative consequences for long-term economic development.

Several other papers are to some extent related to ours. Chaney (2008) and Chaney and Hornbeck (2015) investigate the expulsion of about 120,000 Moriscos in 1609 from the Kingdom of Valencia. Chaney (2008) finds that persistent extractive institutional arrangements in former Morisco areas inhibited the development of the non-agricultural sector long after the adverse population shock. Chaney and Hornbeck (2015) provide evidence of Malthusian dynamics in early modern Spain by documenting persistent rises in output per capita as a result of the population decline caused by the expulsion. Tur-Prats (2015) finds that a historically-determined persistent geographical distribution of traditional family types (stem vs. nuclear) affects intimate-partner violence (IPV). Based on a historical account, she uses the stages of the Reconquest and a freedom of testation indicator as instruments for the different family types. Droller (2013) investigates the effect of migration and population composition on long-run economic development in the settlement of the Argentina's frontier regions known as the Pampas. The channels through which historically higher shares of European population affects current output are associated with industrialization and the level of human capital measured through literacy rates.

This paper also contributes in several ways to a growing body of research that considers economic development as a long-term process with deep historical roots (Spolaore and Wacziarg 2013; Nunn 2014). ${ }^{1}$ First, our case study is appealing in the sense that the historical process studied in this article is very remote in time. The Reconquest ended in 1492 with the fall of Granada yet, significantly, its effects remain visible today. Explaining the reasons for the effect of the Reconquest being so persistent, along with the channels through which it took place, are questions of general interest. Second, our work is also

\footnotetext{
${ }^{1}$ Examples of this vibrant literature are Engerman and Sokoloff (2000, 2002), AJR (2001, 2002), Bockstette, Chanda, and Putterman (2002), Banerjee and Iyer (2005), Angeles (2007), Gennaioli and Rainer (2007), Acemoglu et al. (2008), Baten and van Zanden (2008), Feyrer and Sacerdote (2009), Becker and Woessmann (2009), Iyer (2010), Dell (2010), Gallego (2010), Acemoglu et al. (2011), Bruhn and Gallego (2012), Easterly and Levine (2003, 2016), Ashraf and Galor (2013), Chaney (2013), Cook (2014), Fenske (2013, 2014), Alsan (2015), and Hansen et al. (2015).
} 
interesting because unlike most previous studies focusing on former colonies, it analyzes the experience of a developed economy that became a leading colonial power in the Mercantilist era of colonialism. Third, a particularity of the Spanish case is that over a long period of time its territory experienced a process very similar to colonialism. Thus, an analysis of the Spanish Reconquest is useful because it gives clues about the subsequent colonization of the New World. When Spain colonized Central and South America in the sixteenth century, it had all the experience gathered in the Reconquest and through the policies implemented in the occupation of Muslim lands. Therefore, while the recent literature has emphasized that Spanish colonial policies were significantly influenced by the preexisting indigenous organization in conquered areas (Engerman and Sokoloff 2002; Frankema 2010), it should not be ignored that the granting of large tracts of land to the nobility, for example, had a clear precedent in the homeland. ${ }^{2}$

The remainder of the paper is organized as follows. Section 2 provides a brief historical overview. Section 3 describes the indicator for the rate of Reconquest and the other variables used in the paper. Section 4 presents the analysis of the effect the Reconquest has had on current economic development, while Section 5 provides several sensitivity exercises that include a municipality-level analysis. Section 6 analyzes the timing of the effect of the Reconquest, and Section 7 investigates the possible channels through which this effect occurs. Finally, Section 8 puts forward some implications, and concludes.

\section{Historical Background ${ }^{3}$}

An interesting feature of Spanish history is that for a period of almost eight hundred years the Iberian Peninsula experienced a process somewhat akin to colonialism. In 711, what is now the Spanish mainland was invaded by the Muslims, who in a very short period of time occupied almost the whole of the Iberian Peninsula and created a Muslim domain that was known as al-Andalus. This western European Muslim territory achieved great economic and cultural development, and for most of the period under Moorish rule it was the most advanced country on the continent (Chejne 1999). With the passage of time, the Christian outposts located in northern Spain gradually conquered the Muslim territory in a process

\footnotetext{
${ }^{2}$ In the territories of the southern plateau and Andalusia, the Crown granted large estates (or encomiendas) to the military orders and the nobility (Brenan 1943). "An encomienda was an estate given by the King in señorio, or with full manorial rights, for one lifetime or for some determinate period only. The Comendador was the title of the temporary possessor, who enjoyed all or most of the rights of the King. After the twelfth century encomiendas died out except in the military orders, in which they were the recognized form of land tenure" (Brenan 1943, p. 113).

${ }^{3}$ This historical overview draws on Sánchez Albornoz (1932), Brenan (1943), Dominguez-Ortiz (1955), Herr (1958), Vicens Vives (1969), Malefakis (1970), Sobrequés (1972), Carrión (1975), Ruiz-Maya (1979), Glick (1979), Mestre-Campi and Sabaté (1998), and García-Ormaechea (2002).
} 
that lasted until 1492, with the fall of the Nasrid Kingdom of Granada. This long period of Christian conquest is known as the Reconquista. Military campaigns were followed by a process of colonization or repopulation of the new lands. The way in which the colonization was conducted had fundamental consequences for each region's ensuing development. ${ }^{4}$

The crucial outcomes of the repopulation process were how land was distributed and who held political power. Other potential aspects of relevance were the resulting level of population density, the degree of integration of the Muslim population, and the extent to which preexisting technologies were preserved. An important factor that decisively affected the outcome of the repopulation was the speed of the Christian conquests; that is, whether the Christian frontier advanced rapidly or slowly (Sobrequés 1972; Malefakis 1970). We call this factor "rate of Reconquest". A slow process in this case is generally associated with a more complete and balanced repopulation. This is because a smaller area to be colonized favored the participation of individual settlers and the Crown in the repopulation, which led to better political institutions and a more egalitarian distribution of land. By contrast, a rapid process is associated with imperfect colonization (González Jiménez, 2006). In this case, a larger area to be repopulated implied fewer resources were available relative to the magnitude of the task; that is, an insufficient number of settlers, as well as administrative and military difficulties to govern and defend the territory. This favored the participation of the nobility and military orders in the organization and defense of the new lands.

Figure 1 shows how the rate of Reconquest differs markedly across the different stages of this historical process. During the first three and half centuries of the Reconquest (from 711 to 1062 ) the Christian kingdoms conquered about $155,000 \mathrm{~km}^{2}$, while over the next two centuries (until 1266) the reconquered area almost doubled (about 287,000 $\mathrm{km}^{2}$ ). Thus, the rate of Reconquest (i.e., the area reconquered divided by the duration in years of that period) was much slower in the first period (approx. $441 \mathrm{~km}^{2} /$ year) than in the second period (approx. $1407 \mathrm{~km}^{2} /$ year). These differences had profound consequences for the type of colonization conducted in each case.

\section{[Insert Figure 1 about here]}

A slow rate of Reconquest implied that individual settlers with few economic resources could colonize the territory by themselves. This was the case of the repopulation of the Duero Valley, where the distinctive feature of this process was the predominance of private initiative; that is, a type of repopulation conducted by individuals who occupied land and

\footnotetext{
${ }^{4}$ Spanish historiography labels repopulation as the process of colonization of the reconquered lands by the Christian kingdoms. In this paper, we use the terms colonization and repopulation indistinctly to refer to this process.
} 
acquired its property through the institution of presura or aprisio (i.e., apprehension of land). In general, this repopulation implied a more balanced occupation of the land, as reflected in the presence of a large number of small settlements that appear evenly distributed across the repopulated territory. It also led to the creation of a society with a democratic structure of free peasants with access to land (Vicens Vives 1969). ${ }^{5}$ The Crown also found it easier to organize the repopulation when the area to be occupied was not large. Thus, in the lands comprised between the rivers Duero and Tagus the repopulation was to a large extent officially organized and conducted by the King through the creation of municipalities or councils (repoblación concejil), which delimited and distributed smallholdings among settlers (Ruiz-Maya 1979). When the repopulation was conducted by the Crown, the result was still beneficial to the peasantry, since land was relatively well distributed and cities remained under royal jurisdiction. ${ }^{6}$

In addition, a smaller area to be repopulated (consequence of a slow rate of Reconquest) favored the preservation of Muslim agricultural technologies and the integration of the Muslim population. Indeed, the repopulation in Aragon was different than in Castile, largely due to the smaller area this kingdom reconquered. In this case, the King was able to carefully organize the colonization, and the nobility played a smaller role (Sobrequés 1972). In contrast to Castile, the repopulation of Aragon had such particularities as a higher concern for maintaining irrigation structures, greater respect for the Muslim population, and less reward for the aristocracy for their participation in the conquest and defense of new territories (Casado-Alonso 2002; Vicens Vives 1969).

The above contrasts with the situation in the stages of the Reconquest comprised between 1062 and 1266, particularly in Castile, where the Christian conquests progressed much more rapidly. The larger frontier areas to be repopulated rendered it unfeasible to colonize through individual settlers. Likewise, it was also difficult for the King to be able to organize the repopulation on such a large scale. In this context, the Crown found in the military orders and the nobility the most "effective means of [occupation and] defense in the border region" (Forey 1984, p. 214), ${ }^{7}$ with the latter groups being granted large estates and

\footnotetext{
${ }^{5}$ The northern and mountainous territories that did not fall under Muslim control were characterized by the existence of few large estates, as well as by a social structure composed of a majority of free men and little class differentiation (Glick 1979).

${ }^{6}$ Under royal jurisdiction, the peasantry faced a smaller tax burden than under noble jurisdiction, where seigneurial duties were added to state taxes (García-Ormaechea 2002).

${ }^{7}$ Following the example of the Holy Land crusaders, the Castilians created three great military orders that served as armies for the kingdom to conquer Muslim lands and defend the Christian frontier. The order of Calatrava was founded in 1158, the order of Santiago in 1170, and the order of Alcántara in 1176, all during the second half of the twelfth century, a period from which military orders grew in importance due to their key role in the defense of the frontier (González Jiménez 1989).
} 
jurisdictional rights. This situation was intensified after the Muslim defeat at the Battle of Las Navas de Tolosa in 1212. In a short period of time (between 1225 and 1250), most of the southern third of the peninsula suddenly fell into Christian hands (Malefakis 1970). By the mid-thirteenth century, the Reconquest was almost complete, with the exception being the Nasrid Kingdom of Granada.

The magnitude of the frontier expansion profoundly affected the subsequent social reorganization (Sobrequés 1972; Malefakis 1970). "[G]iven the weak resources of the period, the Castilians had to deploy enormous effort in order to cater for the administration, defense, and economic development of these southern lands [...] Inevitably, the disparity between the magnitude of the task and the precarious resources available produced problems. One of these was the birth of the great landed estates" (Cabrera Muñoz, 1989, p. 465); another was the concentration of political power in the hands of the nobility. It is thus no surprise that the concentration of landownership and the proportion of territory under the jurisdiction of nobles or military orders were the highest in the regions of Castile-La Mancha, Extremadura and Andalusia. ${ }^{8}$ In addition, a rapid rate of Reconquest made it difficult to govern the Muslim population and preserve their agricultural technologies. Thus, the previously intensive agriculture of the Guadalquivir Valley dramatically changed after the expulsion of the Moors from Andalusia following the 1264 revolt, being replaced by an extensive agrarian sector dominated by olive groves and sheep (Vicens Vives 1969; Malefakis 1970).

The existence of a link between the rate of Reconquest and the type of colonization is clearly reflected in the pattern of settlements in Spain. A rapid rate of Reconquest means a scarcity of settlers and economic resources, which gives rise to an unbalanced occupation of the territory consisting of an urban structure of a disperse distribution of few settlements involving large jurisdictional areas. In this sense, López-González et al. (1989) have argued that the size of municipal areas tends to increase as the Reconquest progressed, with the largest being on the Castilian side of Andalusia. There is indeed a very positive relationship between the rate of Reconquest and municipal surface area (measured both in 1787 and 2011). Remarkably, the rate of Reconquest alone explains $61 \%$ of the variation in municipal area in 1787. ${ }^{9}$ This provides additional support for the fact that the scale of the frontier

\footnotetext{
${ }^{8}$ Regarding the possibility that the concentration of land in Andalusia after the Reconquest merely reflected the situation under Muslim domination, Malefakis (1970) states that it is indisputable that land concentration in Moorish times was lower than under Castilian domination.

9 The positive effect of rate of Reconquest on municipality size is robust to controlling for geographic variables such as soil quality, altitude and distance to the coast. As a falsification test, we also show that rate of Reconquest is not significantly related to the average size of ancient (pre-medieval) settlements. Due to space considerations, detailed results are available in (Supplementary) Appendix A.
} 
expansion affected the pattern of colonization of the conquered lands in a manner that is consistent with our line of argumentation.

To sum up, the rate of Reconquest conditioned the type of colonization conducted in each region. A rapid rate favored a political equilibrium biased toward the nobility, creating societies with high levels of economic and political inequality -with other potential consequences being a low integration of the Muslim population and scant preservation of their technologies. In contrast, a slow rate of Reconquest led to a more balanced occupation of the territory and a more egalitarian social structure. We argue that initial differences in the type of repopulation created different development paths across today's Spanish provinces, with implications for their current level of prosperity. Thus, we expect a negative relationship between the rate of Reconquest and current per capita income. After presenting the data used in the paper, the following sections test this prediction and provide evidence on the timing of the effect and the mechanisms at work.

\section{Rate of Reconquest and Other Data}

We construct a database for the 50 Spanish provinces that contains variables concerning the rate of Reconquest, current economic development, and many historical and geographic controls. Our main indicator for measuring the conditions and pace at which the Reconquest was made is labeled "rate of Reconquest". It measures the total area of the stage of the Reconquest in which the province was conquered by Christians, divided by the duration in years of that stage of the Reconquest. Therefore, the rate of Reconquest is a ratio of the amount of reconquered area divided by an interval of years. Intuitively, it reflects the speed at which the Christian frontier advanced and, consequently, the level of colonization effort required for the effective occupation of the province.

We construct this variable as follows. First, using geospatial software we calculate the surface area of each stage of the Reconquest from detailed maps provided by Mestre-Campi and Sabaté (1998). In this first step, we differentiate between the areas conquered by the Kingdom of Castile and the Crown of Aragon. In what follows, for the sake of simplicity, we refer to these 16 Reconquest areas ( 9 for Castile and 7 for Aragon) as Reconquest stages. Regarding the initial area of resistance in northern Spain, since it was not effectively conquered by the Muslims and, therefore, not reconquered, we exclude it from the baseline analysis. ${ }^{10}$ Second, we calculate the duration in years of each stage of the Reconquest as the

\footnotetext{
${ }^{10}$ The initial area of resistance is omitted from the analysis since, arguably, it is not fully representative of the dynamics of the frontier expansion to which the rest of Spain was subjected. In the provincial analysis, this territory comprises Asturias, Cantabria, and the three Basque provinces. Note, however, that the exclusion of these provinces is a conservative decision since our hypothesis may also be applicable to them. This region represents the case of a natural (long-term) repopulation process of a territory, and, therefore, a suitable
} 
difference between the dates associated with each one of the subsequent frontier lines depicted in the map of the Reconquest in Figure 1. Third, we divide the surface area of each stage of the Reconquest by its duration in years. This provides a measure of the rate of Reconquest expressed in $\mathrm{km}^{2} /$ year. ${ }^{11}$ A high value of this indicator implies that the Reconquest progressed quickly in that stage. Finally, we impute the estimated value of the rate of Reconquest to the provinces located in the respective stages. Since the area of a province can partially cover more than one stage of the Reconquest, we calculate the proportion of the provincial area within each one of the respective stages. We then compute the weighted average of the rate of Reconquest for each province, where the weights are given by the percentage of the provincial area conquered in each stage. This renders a different rate of Reconquest for each of the 45 provinces, as shown in Figure 1. Note, for instance, that if $50 \%$ of a province is reconquered rapidly, and the remainder slowly, our measure would reflect an average rate of Reconquest, rather than differentiate between both rates. $^{12}$ However, in the municipality-level analysis we will explicitly allow for withinprovince variation across municipalities, thus allowing for the possibility that different municipalities within the same province exhibit different rates of Reconquest. This more disaggregated analysis will enable us to better account for and understand the persistence side of our theory, since jurisdictional rights were granted at the local level and the evolution of land inequality is also inherent to the dynamics of each municipality. Note, in this regard, that provinces had limited competencies and were indeed regional branches of the central government.

The variable used to measure current economic development is the figure for GDP per capita in 2005 provided by the Spanish National Statistics Institute. This study also employs a number of variables that may act as potential channels for explaining the effect of the Reconquest, as well as measures of pre-Reconquest economic development and a wide array of climatic, geographic, topographic and historical controls. We present all these variables in the sections in which they are used. Their definitions and sources are provided in Table 9 at the end of the main text, while the descriptive statistics are reported in Supplementary Appendix B (Table A2).

comparison group, for which we can assume a rate of Reconquest of zero. As shown below, the effect of the rate of Reconquest is robust to the inclusion of these five provinces.

${ }^{11}$ More specifically, and in order to make the numbers manageable, this indicator is expressed in 100 $\mathrm{km}^{2} /$ year.

${ }^{12}$ We believe this way of proceeding does not conflict with provinces being considered as administrative units. Current provinces are indeed much more recent than the Reconquest itself. They were created in 1833 following Javier de Burgos plan. In addition, provinces are used as observational units because of data availability and because that is the standard practice in this literature. 


\section{The Effect of the Reconquest on Current Development}

\subsection{Initial Results}

Table 1 contains the results concerning the effect of the Reconquest on current levels of GDP per capita. The following equation is estimated with ordinary least squares (OLS) and heteroskedasticity-consistent standard errors with small-sample correction due to the relatively low cross-sectional dimension: ${ }^{13}$

$$
Y_{i}=\alpha+\beta_{1} \cdot \text { Reconquest }_{i}+\beta_{2} \cdot X_{i}+\omega_{i}
$$

where $Y_{i}$ is $\log$ per capita GDP in 2005 in province $i, \alpha$ is a constant term, Reconquest $t_{i}$ stands for our measure of the rate of Reconquest, $X_{i}$ is a vector of control variables, and $\omega_{i}$ is the error term. Entry 1 in Table 1 reports a highly significant, negative bivariate relationship between current GDP levels and the rate of Reconquest for the whole Spanish territory (50 provinces). However, we prefer to conduct the analysis with only 45 provinces, i.e., removing those provinces that were never occupied by the Muslims and, as such, are not representative of the dynamics of frontier expansion applicable to the rest of Spain. Hence, in what follows we focus on the reduced sample of provinces. As with the whole Spain, entry 2 reports a statistically significant negative link between current output per capita and the rate of Reconquest. Our measure of the Reconquest alone explains $26 \%$ of the variation in current GDP per capita. This result indicates that the Reconquest is an important determinant of the current distribution of provincial output. We may compare two provinces with high and low rates of Reconquest to gain a sense of the size of the effect the Reconquest has had on current GDP per capita. For instance, Barcelona has a level of GDP per capita that is $48 \%$ higher than Seville $(24,782$ vs. 16,782$)$. The latter has a rate of Reconquest (expressed in $100 \mathrm{~km}^{2} /$ year) of 21.94, while for the former it is 1.58 . The estimate in entry $2,-0.017$, indicates that Barcelona should be $41.4 \%$ richer than Seville $\left(e^{0.346}-1 \approx 0.414\right)$, which is very close to the real differences in income per capita. This result cannot be taken as conclusive, since the presence of potential omitted factors, if correlated with both the Reconquest and current economic development, would introduce an omitted variable bias in the relevant coefficient. Therefore, in the rest of this section we seek to exhaustively control for possible factors that may affect both the rate of Reconquest and current GDP per capita levels.

A first set of controls is related to the biogeographic conditions 10,000 years ago, and the transition to early agriculture within the Neolithic Revolution. Accordingly, entry 3

\footnotetext{
${ }^{13}$ Throughout the analysis, we apply the Davidson and MacKinnon (1993)'s recommended simple degrees of freedom correction by multiplying the estimated variance matrix by $(n / n-k)$. This Stata's built-in correction is particularly relevant here due to the relatively low cross-sectional dimension.
} 
introduces the percentage of provincial area covered by wooded steppe versus dry steppe. These were the types of Neolithic vegetation (as indicators of soil quality and agricultural suitability) that prevailed on the Iberian Peninsula in prehistory. ${ }^{14}$ Entry 4 incorporates the predicted date of adoption of early agriculture using the information provided by Pinhasi, Fort, and Ammerman (2005) regarding the exact location of thirteen calibrated C-14 dates from Neolithic sites on the Iberian Peninsula. ${ }^{15}$ Statistically, none of the Neolithic controls enters significantly, whereas the effect of the Reconquest remains highly significant and unchanged in size.

A second set of controls accounts for historical conditions that may be relevant factors omitted from our analysis. Entry 5 introduces a variable measuring the road density level in Roman times, which could affect the progress of the Christian conquests, and may also be related to local development potential. This variable enters insignificantly in the regression, without altering the effect of the Reconquest. Entry 6 controls for an indicator of preReconquest economic development, namely, urban population density in $800 .{ }^{16}$ Arguably, the Christian frontier could advance more slowly in more developed regions, because -for example- they offered stauncher resistance. The coefficient on urban population density in 800 is negative and statistically significant, while the effect of the Reconquest remains negative and statistically highly significant. ${ }^{17}$ Following a similar reasoning, entry 7 controls for an indicator of the level of economic development (urban population density) just before the Christians conquered and colonized the territory. In addition, entry 8 includes a variable measuring the average urban population density in the Christian kingdoms at the time of the conquest. This variable sets out to reflect the general level of economic development of Castile or Aragon (depending on the case) immediately before the province was repopulated, since the type of colonization conducted could be affected by the conqueror's level of prosperity at that time. A higher conqueror's level of prosperity can also proxy for

\footnotetext{
14 The omitted category in the regression is dry steppe. Wooded steppe entailed a closed forest, including mixed conifer-broadleaf forest; and dry steppe implied sparse vegetation with open wooded vegetation types and a more temperate climate. See Olsson and Paik (2013) for more details.

${ }^{15}$ Olsson and Paik (2013) use this data source to analyze the effect of the early transition to agriculture on current development in the western agricultural core.

${ }^{16}$ In this regard, we follow Bairoch (1988), de Vries (1976), and more recently, AJR (2002), who argue that urbanization is a good proxy for economic development, since urban societies require an advanced agriculture and a developed transport infrastructure.

${ }^{17}$ One needs to be cautious with the negative coefficient on urban population density in 800 given the low number (only 8 ) of non-zero observations for that year.
} 
the fact that the attacking technology was more advanced. ${ }^{18}$ These two last controls are insignificant in the regression, without affecting the coefficient on rate of Reconquest. ${ }^{19}$

Entry 9 introduces an indicator measuring the number of centuries that the province was under Muslim domination, as a means to account for the legacy of being under Muslim rule for a longer time. Indeed, this may be a confounding variable since a longer Muslim domination could affect factors such as cultural values or the Spanish-Christian identity of the population. Interestingly, the coefficient on rate of Reconquest remains highly robust, while the new variable appears statistically insignificant. ${ }^{20}$ Entry 10 introduces a dummy variable capturing whether the province once belonged to the Crown of Aragon. Certain institutional characteristics of this former kingdom may have had an impact on economic development. The dynastic union between the Crown of Aragon and Castile was forged in 1469 with the marriage of the Catholic Monarchs, but Aragon preserved its legal system and institutions until the War of Spanish Succession at the beginning of the eighteenth century. Arguably, these particularities during this early period could have influenced subsequent economic activity. Even though this historical control appears highly significant and positively related to current development levels, its inclusion does not affect our baseline results. Entry 11 introduces a dummy variable for Madrid, the Spanish capital, in order to control for the fact that its good economic performance may have been driven by its special administrative character. ${ }^{21}$ As expected, the coefficient on Madrid is positive and highly significant.

We next control for various climatic, geographic and topographic factors that may be omitted from the baseline specification. Many scholars consider geography to be an important determinant of economic development (Gallup et al. 1999; Sachs 2003). Following AJR (2002), we may differentiate between simple and sophisticated geographic

\footnotetext{
${ }^{18}$ As documented by, among others, González Jiménez (1989, p. 57), in medieval Castile military potential was closely associated with wealth. Cabrera Muñoz (2006, p. 126) provides several examples of the military power exhibited by the greatest and also wealthiest noble families in the Castilian part of Andalusia.

19 The extent of Muslim weakness is another factor that is likely related to the rate of Reconquest, since it seems clear that the Reconquest advanced faster when the Muslim adversary was weaker. Given the inherent difficulty in measuring Muslim weakness at each point in time and the fact that this factor is orthogonal to the economic potential of the reconquered territories, we do not pursue any further its inclusion in the control set. Note that this orthogonality condition is likely to be satisfied given the full dismantlement of Muslim structures that took place, particularly after the expulsion of the Muslim population from the reconquered territories. See more details on this in Oto-Peralías and Romero-Ávila (2016).

${ }^{20}$ Another possible way to analyze the Muslim cultural legacy is by looking at the Moorish ancestry in the current population of each province. The correlation between Moorish ancestry and the number of centuries under Muslim domination is nonetheless below 5\%. In Section VII we discuss this question in more detail.

${ }^{21}$ In addition to being the seat of government bureaucracy, which represents a flow of rents to its inhabitants, Madrid is the hub of Spain's radial communication network, reflecting traditional government centralism (Herr 1958). This provides the capital of Spain with a privileged position as a business location.
} 
explanations. The first type considers factors such as climate (with effects on work effort), soil fertility, and diseases. It predicts persistence in economic outcomes because geographic factors are time-invariant. Sophisticated geographic hypotheses are more appealing because they allow for the possibility that some geographic factors have a changing economic role over time. Applied to the Spanish case, access to the Mediterranean Sea may have been more decisive during the Middle Ages, with subsequent access to the Atlantic through trade with the Americas, and more recently during the industrialization period to the Bay of Biscay. In addition, coal reserves played an important role during the industrialization period, but not all the provinces had their own reserves. Transportation costs - measured, for instance, through access to the sea or distance from major trading partners and industrial centers in Europe- could also have been more important during the nineteenth century, when commercial relations across regions and countries intensified. In order to dispel doubts, we next control for variables that may be associated with both sets of geographic hypotheses. We begin with factors exhibiting geographic variation along a North-South gradient that mimics the direction of the Reconquest. The incorporation of latitude, in entry 12, (which enters insignificantly) does not affect the statistical significance or size of the coefficient on rate of Reconquest. Therefore, our results do not simply capture the fact that southern Spanish regions are poorer.

Entries 13-15 control for such variables as temperature, rainfall and humidity, which may also affect soil quality and its suitability for crops that require large estates (and in turn induce the concentration of economic power in the hands of the landed elite). Higher aridity and less rainfall may also require a higher concentration of land on the grounds of economic efficiency and profitability (Brenan 1943). Hence, they may be factors that confuse the long-term effect of the Reconquest on development. It is worth stressing that the baseline results remain fairly unaltered, with only rainfall entering significantly. The baseline result remains unchanged when entry 16 introduces a direct measure of soil quality constructed on the basis of several dimensions (nutrient availability and retention capacity, rooting conditions, oxygen availability to roots, excess salts, toxicity and workability) from FAO/IIASA (2010) data, which enters with a highly significant and positive coefficient. Entries 17-19 exploit provincial variation in the suitability of land for such cash crops as sugar, cotton and tobacco in order to capture the possibility of a contrast in the suitability of land for large plantations in the South of Spain as opposed to the North (as in the US). It is worth noting that none of these three controls appears statistically significant or affects the main findings. The introduction, in entries 20 and 21 , of average altitude and terrain 
ruggedness does not alter the baseline results either, with only the latter being marginally significant.

Entries 22-33 control for geographic attributes related to transportation costs that include access to the Mediterranean Sea, the Atlantic Ocean, and the Cantabrian Sea, a dummy indicator for being an island, a coast dummy, coast length over surface area, distance from the coast, border with Portugal, and the natural log of distances from Madrid and London, the latter being considered the technological frontier. Two other distances from locations that were arguably important for European development are included. They are distance from Mainz as a proxy for the spread of the printing press (Dittmar, 2011), and distance from Paris, which can be considered the cradle of the Enlightenment movement that promoted the expansion and accessibility of useful knowledge as a cornerstone of industrialization (Squicciarini and Voigtlander, 2015). ${ }^{22}$ Of all these controls, access to the Cantabrian Sea, border with Portugal and log distances from Paris and Mainz are statistically significant and negatively associated with current development, whereas access to the Mediterranean Sea enters with a statistically significant positive coefficient. Most importantly, the effect of the Reconquest remains fairly robust to these additions. Entries 34-37 control for indicators accounting for natural resource endowments that include the percentage of agricultural land in 1900, the percentage of arable land in 1962, a coal dummy in 1860 , and log coal output in 1860. Only the coal dummy is statistically significant and with a positive coefficient, whereas the baseline results remain unaltered.

\section{[Insert Table 1 about here]}

\subsection{Baseline Specification and Robustness Checks}

Column 1 in Table 2 includes in the same specification all the controls that are individually significant at the $10 \%$ level or better. ${ }^{23}$ This is our paper's baseline specification. Even in this case, the coefficient on the Reconquest measure is significant at the $1 \%$ level, and its size is only slightly reduced from -0.017 to -0.016 . Besides, the Madrid indicator, soil quality and ruggedness continue to be statistically significant and positively associated with current development, whereas log distance from Paris has a statistically significant negative effect on current GDP per capita. The strength of the effect of the rate of Reconquest on current development is illustrated in Figure 2 by a scatter plot of the two

\footnotetext{
${ }^{22}$ These specifications allow us to address the issue of the extent to which the speed of Reconquest varied relative to a uniform movement along the north-east/south-west axis. If our baseline results remain robust to the inclusion of these controls, that would go a long way in addressing endogeneity concerns.

${ }^{23}$ The variable urban population density in 800 that was found individually significant at the $5 \%$ is not included because the existence of only 8 non-zero observations could distort the results for the whole analysis. In addition, we omit log distance from Mainz due to a correlation of $98 \%$ with distance from Paris.
} 
variables, after conditioning on the set of controls included in column 1 . The partial $R$ square of the rate of Reconquest is $34.9 \%$ in this baseline specification. It is remarkable that an indicator measuring a historical event that occurred many centuries ago has such a large explanatory power for explaining current income. ${ }^{24}$

A typical concern of empirical analyses with a limited number of observations is the possibility that a few extreme cases drive the results. Columns 2-7 in Table 2 show that our findings are fairly robust to removing outliers detected by the following procedures: leverage, standardized residuals, studentized residuals, Cook's distance, DFITS, Welsch distance, and DF-Beta. Likewise, the effect of the Reconquest remains fairly unchanged when particularly rich areas such as Madrid and Barcelona are excluded from the analysis (column 8). Similar results are obtained when employing robust estimation that corrects for the effect of outliers (column 9). Our baseline findings also remain robust to using a quantile regression approach (column 10), as a way to assess the existence of an effect at the median and not only at the mean of the distribution.

In addressing the concern that our results hinge on the particular indicator of Reconquest used, we re-estimate the baseline specification with three alternative indicators. First, an alternative indicator of rate of Reconquest that assigns to each province the rate of Reconquest corresponding to the Reconquest stage in which a province's geographic centroid is located. By doing so, there is no need to calculate a weighted average of the rate of Reconquest, and standard errors can be clustered at the level of stage of Reconquest. Second, another alternative indicator of the rate of Reconquest that divides this historical process into stages of the same duration. ${ }^{25}$ Third, a dummy variable indicating whether the province was reconquered after the collapse of the Almohad Caliphate in 1212 following the Battle of Las Navas de Tolosa, which enabled the Christian armies to conquer a vast territory in a short period of time. The results appear in columns 11-13 of Table 2. It is

\footnotetext{
${ }^{24}$ Appendix $\mathrm{C}$ incorporates the rate of Reconquest into the baseline specification in alternative functional forms: in quadratic form, in log-linear form and in quartiles. In the quadratic specification, the rate of Reconquest terms are highly significant, and the negative marginal effect appears linear for most of the values of the rate of Reconquest, only flattening at a value of rate of Reconquest corresponding to the $90^{\text {th }}$ percentile (17.9). In the log-linear specification, log rate of Reconquest enters with a highly significant negative coefficient. In the quartiles specification, the dummies for the second, third and fourth quartiles of rate of Reconquest exhibit a negative coefficient. However, it is the fourth quartile corresponding to the areas in which the Reconquest was conducted faster that has the statistically significant larger negative effect on current development.

${ }^{25}$ More specifically, provinces are classified according to the century in which they were reconquered. For each century, we compute the total land area reconquered in that period, differentiating between the areas conquered by Castile and Aragon. Then, the rate of Reconquest in a given province is estimated as the total land area that was reconquered in the century in which that province was reconquered.
} 
remarkable that the three alternative Reconquest indicators enter with a statistically significant negative coefficient, thus corroborating our baseline findings. ${ }^{26}$

[Insert Figure 2 and Table 2 about here]

In Appendix E, we redo all the estimations in Table 2 with two other alternative smallsample corrections: 1) estimating standard errors through wild bootstrap, and 2) using the leverage-adjusted HC2 estimator recommended by Imbens and Kolesar (2012) and Samii and Aronow (2012). In both cases, our baseline findings remain largely unchanged. Another potential concern is the presence of spatial correlation, which may reduce the true precision of the effect. We re-estimate the models in Table 2 and check that the statistical significance of the coefficient on the rate of Reconquest is not reduced when using standard errors corrected for spatial dependence. For that purpose, we use the Jeanty (2012) Stata command -sphac- with a cutoff of $200 \mathrm{~km}$ (see also Allen, 2015). Unaltered results to this change are reported in Appendix F.

Skeptics may still be concerned with the fact that the Reconquest is very correlated with a North-South gradient for Spain, with a richer North (particularly the Basque Country and Catalonia) and a poorer South (mostly Andalusia). This has been previously addressed in several ways. First, we exclude the three rich Basque provinces from the baseline analysis, which partially mitigate this problem. Second, we show that the effect of rate of Reconquest is robust to the inclusion of latitude, and log distances from London, Paris and Mainz. Third, we also omit such potential outliers as Madrid and Barcelona. In addition to the aforementioned robustness checks, i) we incorporate a high-order (cubic) latitude/longitude polynomial into the baseline specification, with the coefficient on rate of Reconquest being robust to this addition. ii) We regress the rate of Reconquest on the set of controls in the baseline specification, save the residuals and use them in a regression of latitude on the residuals. ${ }^{27}$ It is worth noting that latitude appears unrelated to the residuals that are the part of the rate of Reconquest orthogonal to the controls, with an $R^{2}$ of 0.001 and a p-value associated with the coefficient on the residuals of 0.893 . Likewise, once we control for the baseline control set, there is no relationship between latitude and Reconquest rate. All these results are reported in Table A9 in Appendix G. iii) The next section conducts the analysis at municipal level controlling for province fixed effects and for dummies of deciles in latitude.

\footnotetext{
${ }^{26}$ See Appendix D for a replication of tables 1 and 2 when using the full sample of provinces.

${ }^{27}$ In this regard, we follow Sakalli (2014) who faced an East-West gradient problem in his analysis of the effect of coexistence of different religious groups on Islamic religiosity, secular education and development in the context of the deportation of the Armenian population in Turkey in 1915-16.
} 
As an additional robustness check, we only exploit the variation from the 16 regions corresponding to the respective stages shown in Figure 1 (9 in Castile and 7 in Aragon). This analysis is thus conducted with only 16 observations, in which the weighted average of output per capita in 2005 for the territory corresponding to each Reconquest stage (using provincial surface area in each stage as weights) is regressed on the rate of Reconquest at the stage level. As expected, there appears to be a statistically significant negative relationship between both variables. ${ }^{28}$

\section{Sensitivity analysis}

\subsection{Municipality-level Analysis}

Although the relationship between the rate of Reconquest and current GDP appears robust to the inclusion of many geographic and historical controls, as well as to the removal of outliers, a possible objection is that some unobservable province-level characteristics are driving this result. One way to address this concern is to conduct the analysis at a finer level, namely, using municipality data, and test whether the results hold even when conditional upon province-specific fixed effects. This test is quite strong, and allows us to exploit within-province variation in the conditions surrounding the Reconquest. The inclusion of such powerful fixed effects enables us to account for any systematic and structural particularities related to the history of each province, which cannot be controlled explicitly in a province-level analysis. It also provides an alternative way to deal with the issue of small sample. For this exercise, we create a dataset of more than 8,000 municipalities in Spain. As proxies for income at local level, we use current data for average socioeconomic conditions, average number of vehicles per household, and labor force activity rate, which appear clearly linked to economic development. This is corroborated by the existence of a high correlation with GDP per capita at provincial level (the correlation is 0.81 with average socioeconomic condition, 0.54 with average number of vehicles per household, and 0.73 with labor force activity rate).

The municipality-level analysis is conducted with three different measures of rate of Reconquest computed at municipal level. First, the baseline measure is obtained by imputing to each municipality the rate of Reconquest corresponding to the Reconquest phase to which the municipality belongs. As with the province-level analysis, here we distinguish between the stages of the Reconquest in Castile (9 stages if we exclude the initial resistance area) and Aragon (7 stages). By exploiting within-province variation across municipalities, we allow for the possibility of different rates of Reconquest across a

\footnotetext{
${ }^{28}$ A scatterplot and some regressions, controlling for the latitude coordinate corresponding to the centroid of each Reconquest stage, are presented in Appendix H.
} 
province's municipalities. Second, we construct a dichotomous indicator of rate of Reconquest, which equals one if the rate of Reconquest corresponding to municipality $i$ is higher than the provincial mean value. This allows us to exploit the discontinuity in rate of Reconquest across municipalities within each province, in a similar spirit to a border specification. Third, we proceed in a similar way, but exploiting those cases in which there is a stronger discontinuity. The binary indicator is now defined as one, if rate of Reconquest is higher than a 1.25 -fold the provincial mean value.

Table 3 presents the results clustering standard errors at the level of stage of Reconquest. All regressions in Panel A include province dummies and a relatively large control set, which comprises the municipalities' total population (in logs) to control for differences in municipal size, latitude, and geographic factors related to transportation costs, such as distance to Madrid, distance to the coast, and distance to the nearest provincial capital (all distances entering in linear and square form), and a provincial capital dummy, as well as several additional variables accounting for the municipalities' climate, geography and topography. These include altitude, annual average temperature, annual rainfall, and seven dimensions measuring soil quality (nutrient availability and retention capacity, rooting capacity, oxygen availability to roots, excess salts, toxicity, and workability). ${ }^{29}$ Despite the fact this municipality-level specification controlling for province fixed effects goes some way in addressing the North-South gradient concern -as variation in latitude within provinces is much smaller than when considering Spain as a whole-, we deepen into this issue by further incorporating latitude fixed effects (one dummy variable for each decile in latitude). By doing so, we are able to exploit variation within provinces and within each small range of latitude, i.e., within small North-South distances. These results are reported in Panel B of Table 3.

It is worth noting that the three different measures of rate of Reconquest are negatively associated with the three proxies for local development, in most cases at the 5\% significance level or higher. Interestingly, when the rate of Reconquest is constructed in a way that it captures a higher discontinuity, the negative effect becomes more pronounced, as expected. All these findings carry over to the more complete specification that incorporates ten latitude decile dummies. This alleviates our concern that unobserved heterogeneity at provincial level and/or a North-South gradient might be the driving force behind the

\footnotetext{
${ }^{29}$ The inclusion of all these controls together, along with the province-level fixed effects, is particularly important here. This is because with only 45 observations in the province-level analysis, we could not control for all the individual regressors together, since we would run out of degrees of freedom. Instead, we opted for including in the same specification only those regressors that were found individually significant at least at the $10 \%$ level.
} 
significant effect of the Reconquest on current development found in the province-level analysis. $^{30}$

\section{[Insert Table 3 about here]}

Since spatial correlation in this municipality-level analysis can be substantial, as an alternative to clustering the standard errors at the level of stage of Reconquest, we redo Table 3 using standard errors corrected for spatial dependence following Jeanty (2012). We use a cutoff of $100 \mathrm{~km}$ beyond which spatial correlation is assumed to be zero. As an additional robustness check, we conduct the analysis with standard errors clustered at the province level rather than at the level of stage of Reconquest. Our baseline findings in Table 3 remain fully robust to these changes. Due to space considerations, these results are presented in Appendix $\mathrm{J}$.

\subsection{Falsification Test and Balancedness}

This section conducts a falsification exercise to show that the rate of Reconquest is not negatively related to the level of economic development in the pre-Reconquest era. A main threat to the validity of our analysis is the possibility that areas conquered faster were initially poorer, which could have facilitated a rapid conquest. If those areas conquered faster were worse off even before the Reconquest, then the observed relationship between the rate of Reconquest and current income may be driven by the territories' intrinsic characteristics, rather than by the type of colonization conducted by Christians. However, it is very unlikely that the rate of Reconquest hinged on the territories' economic development, since the pace of the advance of the Christian frontier was arguably caused mainly by the relative military weakness of the Muslim territory in each period. Therefore, the rate of Reconquest was the consequence of an exogenous factor with respect to the territories' economic potential.

Our aim is to verify that our indicator of the Reconquest does not have a statistically significant negative association with economic development and other outcome variables before the Reconquest. We measure pre-Reconquest development primarily through city

\footnotetext{
${ }^{30}$ As we did for the province-level analysis, we can conduct the analysis using only the 16 Reconquest stages as observational units. The dependent variable in this case is the average value of each of the three proxies for local development, and the independent variable is the rate of Reconquest. Not surprisingly, there exists a negative relationship between both variables, even after controlling for the latitude coordinate corresponding to the centroid of each Reconquest stage. A scatterplot and the regression outputs are presented in Appendix I. An additional exercise, shown also in Appendix I, is to regress local development on the 16 stages-ofreconquest fixed effects (one dummy variable for each stage) and latitude, for the sample of 7644 municipalities. This specification only exploits within stage-of-reconquest variation. The absence of a statistically significant relationship among the three municipality-level outcome variables and latitude within Reconquest stages is reassuring that a North-South gradient is not driving our results.
} 
population and urban population density in 800 , which is the earliest year for which urban population data are available. Given that the Reconquest had hardly begun at that time, it serves our purpose. We also consider additional outcome indicators related to preReconquest development. These include years since the transition to agriculture, ancient (pre-medieval) settlements over surface area, Roman road density (total roads and main roads), the ratio of the number of locations where imperial coinage was found to surface area, Roman villas over surface area, and density of bishoprics circa 600.

To assess whether these variables can be used as plausible measures of early development, we look at their correlation with an indicator of land suitability for agriculture -the percentage of agricultural area in 1900-, since pre-industrial prosperity is commonly considered to be related to soil fertility and, more specifically, to agricultural land potential. Remarkably, all the indicators - except for years since the transition to agriculture- are positively correlated with the percentage of agricultural area. In the case of city population and the density of urban population in 800, Roman road density -total and main roads-, presence of imperial Roman coinage, and Roman villas, correlations are statistically significant. ${ }^{31}$ Very similar correlations follow when we employ the variable percentage of arable land in 1962 as a measure of land suitability for agriculture. These results indicate that most indicators of pre-Reconquest development reveal expected relationships with agricultural land potential, which makes us more confident about their reliability.

Panel A of Table 4 provides the results on the relationship between the rate of Reconquest and early development. It is worth noting that the rate of Reconquest is not negatively associated with any of the measures of early economic development, after conditioning on a meaningful set of controls. ${ }^{32}$ Fairly similar findings follow when we look at the bivariate relationship between rate of Reconquest and pre-Reconquest development, which appears marginally significant at the $10 \%$ level (though with a positive sign) only in the case of ancient settlements (see Panel B of Table 4). The above findings suggest that the effect of the Reconquest does not merely represent the perpetuation of differences in economic development that already existed before the Reconquest, or mean that provinces conquered more rapidly started off at a disadvantage or were intrinsically poorer.

[Insert Table 4 about here]

\footnotetext{
${ }^{31}$ For total Roman road density, the coefficient of correlation is significant at the $10.7 \%$ level. Detailed results are provided in Appendix K.

32 This analysis omits those control variables that are meaningless when the dependent variable is a measure of pre-Reconquest development, namely, Crown of Aragon, Madrid, border with Portugal, the coal dummy, and distance from Paris as the cradle of the Enlightenment movement.
} 
We next present a balancedness table showing the correlation between rate of Reconquest and urbanization levels measured through density of urban population from 800 to 1850 . The evidence shown in Panel A of Table 5 mostly points to a lack of a statistically significant relationship between rate of Reconquest and urbanization levels for more than a millennium. ${ }^{33}$ Therefore, neither initial nor subsequent development prior to the arrival of industrialization around 1860 is clearly correlated with rate of Reconquest. This indicates two things. First, as already pointed out, those territories conquered faster were not initially poorer. Second, the adverse effect of a fast Reconquest on aggregate economic development did not become apparent before industrialization. We extend on this point in Section 6.

Panel B of Table 5 further presents the bivariate relationship of rate of Reconquest with soil quality measured both at provincial and municipal levels, as well as with eight other measures of land quality and land productivity. With the exception of soil quality at province level, there does not appear to exist a statistically significant relationship. As regards the positive correlation between rate of Reconquest and soil quality at province level, one could argue that it is this confounding factor, rather than the pace of the Reconquest, that affected the concentration of economic power in the form of land (which is a main channel through which the effect of the Reconquest is found to operate) and in turn the level of development. However, there are reasons to believe this is not the case. First, our baseline specification already controls for soil quality. Second, there is not a statistically significant relationship of rate of Reconquest neither with soil quality at municipal level, nor with eight different proxies for land quality and productivity measured at province level. Third, it is clear that what matters for the concentration of land in large estates regions is the historical process of Reconquest rather than soil quality. This is because our data indicate the existence of a positive (instead of an expectedly negative) relationship between the extent of land inequality (measured through the percentage of landless workers over the total agricultural active population in 1797) and soil quality for the Spanish provinces, with a correlation coefficient of 0.62 . This contrasts with the existing evidence that supports that areas with better soil quality historically experienced a higher demand for land, which should be conducive to higher land fragmentation (see Baten and Hippe, 2013, and Cinnirella and Hornung, 2013, for such evidence across the European regions and Prussian counties in the nineteenth century, and references therein). Hence, it is reasonable to think that had the Reconquest not occurred, the more fertile provinces would have given rise to small and medium-size holdings. Fourth, in the context of the two-stage-least-squares (2SLS) analysis implemented in Section 7 -in which the rate of Reconquest is found to

\footnotetext{
33 There appears to be only a marginally significant positive relationship for the cases of density of urban population in 1000, 1200 and 1700 .
} 
affect current development mainly through land inequality-, when historical land inequality is instrumented with soil quality (instead of with rate of Reconquest), it no longer affects current development. However, rate of Reconquest that entered exogenously would still exert a statistically significant negative impact on log GDP per capita in 2005. These results appear in Appendix L. This makes it clear that current output is affected by structural inequality stemming from the conditions surrounding the Reconquest rather than from soil quality.

\section{[Insert Table 5 about here]}

\section{The Timing of the Effect of the Reconquest}

The above results confirm the strong and robust negative effect that the Reconquest has had on current per capita output. A question that requires further study is when this effect actually took place. This is a key issue because it provides clues about the nature and causes of the effect. On the one hand, if our findings were due to -for example- some geographic confounding factor, the effect of the Reconquest would probably be visible at all times. ${ }^{34} \mathrm{On}$ the other hand, the analysis of the timing of the effect is useful for considering the mechanisms at work. For example, if the main implications of the rapid advance of the Christian frontier were related to the destruction of Muslim technologies or to a lack of agglomeration economies due to low population density, the negative effect should have become apparent soon after the Reconquest.

To implement this analysis, we estimate a panel specification that regresses each province's level of development relative to the national average over the 1000-2005 period on the interaction between rate of Reconquest and time dummies, with data measured at the beginning of each century up to 1800 , and then at 1860, 1930, 1970 and 2005. The interactions start in 1500, which roughly corresponds to the year in which the Reconquest ended. The specification takes the form:

$$
y_{i, t}=\alpha_{i}+\theta_{t}+\sum_{t=1500}^{2005} \gamma_{t} \cdot D_{t} \cdot \operatorname{Re} \text { conquest }_{i}+\sum_{t=1500}^{2005} \phi_{t} \cdot D_{t} \cdot X_{i}+\varepsilon_{i, t}
$$

where $y_{i, t}$ stands for each province's relative level of development. For the periods prior to 1860 for which there are no available data on GDP per capita, we employ density of urban population. $D_{t}$ is an indicator variable for each time period, Reconquest $t_{i}$ represents the province-level rate of Reconquest, $X_{i}$ includes those controls that may have a varying effect over time such as soil quality, access to the Cantabrian Sea, a coal dummy, access to

\footnotetext{
${ }^{34}$ In this regard, the evidence presented so far dismisses such a possibility, since the effect is quite robust to many geographic controls, and the rate of Reconquest is not related to indicators of early development.
} 
the Mediterranean Sea and log distance from Paris, and as such they are interacted with the time dummies. $\alpha_{i}$ and $\theta_{t}$ represent province and time fixed effects, respectively.

As shown in Table 6, the panel specification including the interacted rate of Reconquest as well as time and province fixed effects renders a coefficient on rate of Reconquest that becomes negative and statistically significant since 1860, around the time when Spain entered the industrialization phase (Pascual and Sudriá 2002; Rosés 2006). ${ }^{35}$ The interaction terms for the periods prior to industrialization enter with a negative, though statistically insignificant, coefficient. These results suggest that the adverse effect of a fast Reconquest became more apparent when industrialization arrived. The same essentially holds for the panel specifications that add interactions of time dummies with soil quality, access to the Cantabrian Sea, a coal dummy and access to the Mediterranean Sea, respectively.

\section{[Insert Table 6 about here]}

In Appendix M (Table A17) we also estimate specification (2) with data only covering the 1860-2005 period. By doing so, we do not mix in the same specification two different proxies for economic development such as density of urban population and GDP per capita. The analysis is conducted with both relative levels of GDP per capita and relative levels of industrial output per capita, as alternative measures of province-level relative economic development. In this specification the interaction term for 1860 is omitted, since it is taken as the reference period. The evidence appears in line with that obtained for the specification covering the full period. ${ }^{36}$ Appendix $O$ pursues this question further by taking into account that the exact timing of industrialization in Spain may be endogenous. The unreported evidence indicates that the negative effect of a fast rate of Reconquest became more pervasive when the opportunity to industrialize arrived.

\section{Mechanisms at work}

\footnotetext{
${ }^{35}$ The fact that Spain began its industrialization around 1860 is well reflected in the evolution of the railway network, which grew from less than 400 kilometers in 1855 to 5,076 kilometers in 1866 (Pascual and Sudriá 2002).

${ }^{36}$ Appendix N contains several tables regressing log GDP per capita in 2005 on the alternative proxies for level of development available in Spain since the year 800: density of urban population over the 800-1850 period, urbanization rate over the 1600-2001 period, and log industrial output per capita between 1860 and 2005. Over the 800-1000 period, one can observe negative correlations, which could be due to the low number of non-zero observations for such periods. From 1000 to about 1850 correlations appear highly insignificant and very low, whereas it is only since 1860 that higher correlations are observed. This suggests that income persistence in Spain is a late nineteenth- and twentieth-century phenomenon. A very intuitive picture of these correlations is provided in Figure A6 in Appendix N. In the same appendix there is also a table showing the relatively high and positive correlation among the three development proxies at several points in time since 1860 .
} 
In Section 2, we argued that the rate of Reconquest was a crucial factor affecting the outcome of the repopulation process. A rapid rate is generally associated with imperfect colonization, with negative consequences for each region's subsequent development. The rapid advance of the Christian frontier made the task of repopulation more difficult and demanding, which originated several problems, such as scarcity of settlers and resources, defense requirements for vast territories, and the governance of a large conquered Muslim population. What follows describes the potential channels that may help explain the effect of the Reconquest on current development, as well as the way they can be measured. We also discuss the consistency of each alternative explanation with the observed timing of the effect.

\subsection{Structural Inequality Stemming from Land Inequality and Political Power Concentration}

Spanish historiography suggests that two key outcomes of the repopulation process were how land was distributed and who held political power. This constitutes our main hypothesis concerning the main channel through which the Reconquest affected current development, and the argument deserves to be further developed. The rate of Reconquest affected the possibility that either individual settlers or the nobility and military orders gained control over the newly conquered territories. As historically documented, a greater area to be repopulated increased the likelihood that nobles and military orders were called upon to participate in the repopulation and defense of such vast territories. Consequently, a rapid frontier expansion favored an initial political equilibrium biased toward the nobility, which led to the concentration of political power -in the form of jurisdictional rights - and economic power -in the form of land-in the hands of this social group.

The consequences of this unequal distribution of economic and political power were pervasive. Jurisdictional rights provided the landowning nobility with the legal and political apparatus that afforded them de jure political power over the broad mass of the population. This meant the landless peasantry became attached to the nobles' lands, and the judiciary, the right of taxation and local council were controlled by the nobility. Likewise, the nobility could run de facto extractive institutions aimed at exploiting the peasantry through such mechanisms as severe restrictions on land and grain transactions, labor contracts with caps on agricultural wages, land tenure systems implying short-term leases whose conditions were reviewed annually, and the obligation to use the nobles' mill to grind the grain. In this context, institutions of equal opportunity and property rights access for the agricultural proletariat of large estates -who were the majority in southern Spain- were completely 
absent (Brenan 1943; Dominguez-Ortiz 1955). This created a society characterized by a high level of social and political inequality.

This situation persisted over time, in a clear process of path dependence. It can be explained by several factors. First, the decline in population after the Christian conquest due to migrations, the expulsion of the Muslim population, and epidemics favored the establishment and consolidation of a type of extensive agriculture based on large estates (Malefakis 1970). Second, the landed nobility used their political power to illegally usurp lands and monopolize common lands (Cabrera Muñoz 1989). Third, such inefficient institutions as the creation of entailed estates protected by law (mayorazgos) and other regulations made land non-conveyable, and jurisdictional rights were hereditary. The liberal reforms of the nineteenth century derogated the legal apparatus of the Old Regime, but unlike in other countries like France, they failed to suppress nobles' landownership and hence change the balance of power in society (García-Ormaechea 2002). Finally, the process of disentailment of communal and ecclesiastical landownership known as desamortización aggravated the pattern of land concentration in a few hands because land was bought up at very low prices by the rich, the bourgeoisie, and nobles (Brenan 1943; Herr 1974; Carrión 1975). ${ }^{37}$ In Brenan's words, “this is the class that since 1843 has held political power in Spain -a middle class not enriched by trade or industry but by the ownership of land" (Brenan, 1943, p. 109). ${ }^{38}$

As argued by AJR (2002), when a major shock like the spread of industrial technology occurred with the arrival of the opportunity to industrialize, the landed elite may not support investing in the new technology for fear of losing its political power. The reasons are that potential entrepreneurs with productive ideas may not form part of the elite, and thus feel their property rights are not secured. Also, the landed elite may block these investments if those who mostly benefit from them are not part of the elite, thus preventing any shift in the balance of power toward the emerging capitalist class. ${ }^{39}$ In the case of Spain, particularly in

\footnotetext{
${ }^{37}$ The disentailment absorbed a large mass of capital, which would have been otherwise devoted to forming an industrial base or constructing the railroad network with domestic capital.

38 According to Nadal (1997, p.64), the suppression of the Ancient Regime and the process of land disentailment clearly acted in favor of the landed nobility - which increased the ownership of land holdings to a much larger extent than the loss in jurisdictional rights- and against the mass of landless peasants, who shifted from a status of serfdom with access to land to one of free men deprived of land. And those that remained as tenants experienced a dramatic increase in the rent paid to landlords. All this would betray the spirit of the liberal legislators of the Cádiz Constitution of 1812, which was nonetheless abolished in March 1814 by a military coup by Ferdinand VII who restored an absolutist regime until the mid 1830s.

${ }^{39}$ Galor, Moav, and Vollrath (2009) provide an interesting link by which land inequality may lead the landed elite to block education reforms, and thus, the transition from an agricultural to an industrial society. This argument may be applicable to the Spanish case, given the large differences in land inequality across provinces. Our evidence below shows that a faster rate of Reconquest working through a more unequal distribution of economic power is associated with lower literacy and enrolment rates.
} 
large estates regions, the broad mass of the population was poor and no strong bourgeoisie arose, as the entrenched nobility and the middle class preferred to devote their capital to buying large land lots. As a result of this, the industrial revolution largely failed, and unlike in other countries like Britain (Doepke and Zilibotti, 2008), the landed elite did not see its power curtailed and no significant shift in the balance of power occurred. In contrast, in those regions that had a more equal distribution of economic and political power, like the Basque Country and Catalonia, the arrival of the opportunity to industrialize clearly shifted the balance of power toward the emerging industrial bourgeoisie.

According to this line of reasoning, the presence of extractive institutions that do not provide equal opportunity and property rights access for a broad cross-section of society became more important with the arrival of new technologies that required the economic participation of broad segments of the population, most of which were not part of the ruling elite. This appears to be the case with industrialization which, in order to succeed, would require the involvement of new entrepreneurs, innovators, and middle-class citizens. ${ }^{40}$ Applied to the Spanish case, inequality in the access to land (a key historical factor of production) and the associated structural inequality in the access to economic opportunities (schooling, health care, access to credit, etc) precluded large segments of the population in large estates provinces from participating in economic activity when Spain entered the industrialization phase. ${ }^{41}$ This contributed to the failure of southern Spain to industrialize (Nadal 1997; Nadal, Carreras and Sudriá 1987). For these reasons, the role of land inequality and political power concentration as mechanisms for explaining the effect of the Reconquest on income appears fairly consistent with the possibility that this effect became apparent during industrialization.

One might wonder whether the mechanism proposed is based on a conflict between the landed elite and the masses (as in Engerman and Sokoloff, 2002, and AJR, 2002), or on a conflict between the landed nobility and the emerging industrial elite (as in Galor, Moav and Vollrath, 2009). Arguably, we place more emphasis on the existence of a conflict of the landed nobility and the landless masses, which were excluded from participating in economic activity when the opportunity to industrialize arrived. Among others, Domenech (2012, 2015) provides evidence of the existence of rural conflict between the landed elite and the landless masses before the Spanish civil war. This does not preclude the possibility

\footnotetext{
${ }^{40}$ In AJR (2002, p. 1273)'s words, “extractive institutions may become much more inappropriate with the arrival of new technologies. [...] Therefore, there are reasons to expect that institutional differences should matter more during the age of industry".

${ }^{41}$ See Appendix P for a more detailed account of the implications of persistent inequality in the distribution of land in Spain.
} 
of a conflict between the landed and industrial elites. However, for the case of the large estates regions of Spain, we are skeptical about that possibility, since strictly speaking the industrial elite as a social group was very small. One of the reasons for this is that the middle classes preferred to buy disentailed land, rather than invest in industry or building the railway network. The implications of this prevalence of the landed elite were pervasive. By blocking education and equal opportunity access to the masses, the landowning nobility ensured excess of agrarian labor supply and cheap wages, thereby preventing a rural exodus to the cities. In addition, the existence of a broad mass of the population formed by impoverished landless workers, who lacked human capital and financial resources, was not conducive to the accumulation of capital and the creation of an agricultural sector that could provide a strong market for industrial goods (Tortellá, 2000). Without having necessarily existed a conflict between the landed nobility and an industrial elite, all these factors negatively affected the possibility of successful industrialization in large estates regions (Tedde de Lorca, 1985).

One might also wonder why the presence of extractive institutions for the landless majority may not exert an adverse effect on economic activity even before industrialization when an agrarian economic structure predominated. The reason is as follows. In an agricultural society (like preindustrial Spain) in which the main investment opportunities are in agriculture, economic and political inequality may not impair aggregate production. This is because "the elite can invest in land and employ the rest of the population, and so will have relatively good incentives to increase output" (AJR 2002, pp. 1272-3). Along similar lines, Chaney and Hornbeck (2015), found for preindustrial Valencia that there was relatively high output per capita because fertility and mortality did not respond due to the presence of extractive institutions on the peasantry. Similar Malthusian dynamics are likely to apply to southern Spanish regions. In addition, in pre-industrial times, other factors such as soil fertility or environmental suitability may have been more important for production. ${ }^{42}$ In this sense, until industrialization, the higher land fertility of some of the large estates regions was sufficient to make them stand among the wealthiest in Spain. ${ }^{43}$ In short, the adverse effect of extractive institutions on aggregate production may be inconsequential in

\footnotetext{
${ }^{42}$ The plantation system in the Caribbean that employed slave labor is a case in point, since a small landed elite forced the vast majority of the population to work for low wages.

${ }^{43}$ For example, still in 1860 , at the beginning of the industrialization period, Andalusia was the second wealthiest region, ahead of Catalonia and the Basque Country, with a level of GDP per capita about 36 percentage points above the Spanish average. Yet just seventy years later, in 1930, Andalusia was among the poorest regions, with a level of GDP per capita of only $77 \%$ of the Spanish average (data from Rosés et al. 2010). See Appendix Q for a case study of our theory applied to the diverging development paths of Seville versus Barcelona.
} 
an agrarian economy, but not in an industrial one. That is why the negative effect of the rate of Reconquest mostly emerges from 1860 onwards.

We employ several variables to account for the sources of structural inequality. We measure political power concentration of the nobility -and in turn the extractive institutions to which it gave rise- with an indicator from the 1787 population census: the percentage of population entities (núcleos de población) under seigneurial jurisdiction that includes both nobles and military orders. ${ }^{44}$ Land inequality is measured through the percentage of landless workers over the total agricultural active population measured both in 1797 and 1956, which proxy for the concentration of land in the hands of the nobles. The class of landless laborers, which can be traced back to the fifteenth century, was a by-product of the nobility's high concentration of land (Cabrera Muñoz 1989). ${ }^{45}$ For robustness purposes, Appendix R also presents the results with two alternative measures of land concentration: the percentage of arable land in holdings greater than 200 hectares in 1962, and a Gini index of land concentration in 1970 .

\subsection{Other Potential Intervening Factors}

The rate of Reconquest could also affect other factors of relevance to economic development. A first candidate is the extent to which the preexisting Muslim population was respected and integrated into the Christian kingdoms. A rapid frontier expansion made it difficult to govern and integrate this population, as became apparent with the great mudejar revolt of 1264, which led to the expulsion of the Muslim population from the Guadalquivir Valley. In addition to creating problems of labor scarcity, the fate of the Muslim population had important implications due to their higher human capital, particularly concerning the level of agricultural technology. ${ }^{46}$ Moreover, the degree of assimilation of the Muslim population could also have cultural implications. Indeed, Chaney and Hornbeck (2015)

\footnotetext{
${ }^{44}$ We proceed in this way because military orders were mostly composed of members of the nobility, with masters (maestres) and commanders usually forming part of the higher nobility (Vicens Vives 1969; MestreCampi and Sabaté 1998; Alvarez-Palenzuela 2002).

${ }^{45}$ We consider this as a clear-cut proxy for historical structural inequality, which is referred to as a type of inequality that is historical in the sense that has exhibited high persistence over centuries, and structural in the sense that it is a class-based inequality that measures the relative size of the landless workers class relative to land owners and tenants. In an agrarian economy where land is a major factor of production, if landownership is highly concentrated, broad segments of the population have to work for landlords, earning low wages and living in miserable conditions. This was indeed the situation for a broad mass of the population in large estates regions.

${ }^{46}$ al-Andalus, the unique Muslim domain in Western Europe, achieved by far the highest level of prosperity on the continent (Chejne 1999). Its economy was based on a developed and partially irrigated agriculture, a significant arts and crafts industry and flourishing trade. Furthermore, a monetary system was in place, contrasting with the primitive economy of the northern Christian kingdoms (Vicens Vives 1969, Glick 1979).
} 
document differences between Christians and Muslims in their preference for child quality vs. quantity (Galor and Moav, 2002), as well as in fertility and mortality (Galor and Weil, 1996). To measure this factor, the best we can do is use an indicator of the proportion of Moorish ancestry in the current population of each province. Using an admixture approach based on binary and Y-STR haplotypes, Adams et al. (2008) were able to identify the genetic differentiation of the population of the Iberian Peninsula and the Balearic Islands, finding a relatively high mean proportion of ancestry from North Africa (10.6\%). As opposed to the common expectation that a South-North gradient of North-African ancestry is followed, it is worth noting that the highest proportions of Moorish ancestry (greater than $20 \%$ ) are found in Galicia and Northwest Castile, which contrast with the much lower proportions in Andalusia. ${ }^{47}$

A second potential channel through which the Reconquest might affect current development is the traditional family type distribution. Tur-Prats (2015) finds that those areas featuring traditional stem families, in which one son inherits all the land and cohabits the parental home along with his wife to continue the family line, are associated with lower IPV and greater gender equality. This contrasts with the higher IPV found in those areas in which nuclear families -whereby all children receive an equal share of the inheritance and leave the parental home to constitute independent households- are more prevalent. According to Tur-Prats (2015), stem families were dominant in the North because the early stages of the Reconquest gave rise to small and medium-size landholdings, which were preserved by free families through indivisible inheritance. However, as the Reconquest advanced further South, military orders and nobility were awarded with vast tracts of land, and the landless peasantry had no choice but to comply with the equal inheritance rules mandated by Castilian Law, thus giving rise to nuclear families. Therefore, the traditional family type mechanism may be confused with those related to the concentration of political power in the hands of the nobility or even to the extent of land inequality. We investigate the validity of this channel by measuring the historical distribution of family types through the average number of married and widowed women per household at province level from the 1860 census, as in Tur-Prats (2015).

A third possible mechanism that may affect current levels of development is the degree of market fragmentation. Grafe (2012) points to the exceptionally high degree of market fragmentation observed in Spain over the seventeenth and eighteenth centuries as the main

\footnotetext{
${ }^{47}$ It is also worth mentioning the marked differences between the western part of Spain, with a relatively high proportion, and the eastern part with a relatively low proportion. Adams et al. (2008) seek to explain these differences in the history of enforced relocation and expulsion of the Moorish population.
} 
obstacle to economic development. In addition, market fragmentation could be the consequence - at least in part- of accelerated colonization by, for instance, making it more difficult to maintain the pre-existing infrastructure network. We measure differences in the degree of market fragmentation across provinces by constructing an indicator of road density in 1760 at provincial level, with higher road density implying less fragmented markets. This indicator can also be used to test for possible differences in government investment in infrastructure across provinces.

One might also assume that the Reconquest generated historical differences both in the political power of the Church and in religiosity across provinces, which might have had some effect on current development. To control for this factor, we employ two indicators measured at the end of the eighteenth century: the percentage of population entities under Church jurisdiction, and the percentage of population that was a member of the clergy (both secular and regular). A related factor is the role played by the Inquisition, which was charged with preserving Catholic orthodoxy. Vidal-Robert (2014) shows that inquisitorial activity is negatively associated both with urbanization rates at regional level and population growth at municipal level. However, a lack of consistent data for constructing an indicator for the majority of the Spanish provinces has prevented us from empirically assessing the role of the Inquisition in mediating the effect of the Reconquest.

Another mechanism that remains uncontrolled involves interregional migration, which is historically hard to measure. However, there may be reasons explaining why people do not move between regions to arbitrate the existing differences in economic development. One simple explanation may be found in Gennaioli et al. $(2013,2014)$, who develop a model in which there are frictions related to the limited supply of land and housing that prevent people from completely arbitrating away the differences in income. Besides, migration in our case would act against our identification strategy, since if income differences were swept away because of interregional migration, we would no longer find an effect on current income differences, which would have vanished over time.

Finally, the rapid advance of the Christian frontier gave rise to sparsely populated territories due to a lack of manpower and settlers, which was aggravated by the eventual expulsion of the conquered population. However, strictly speaking, population density cannot be considered a channel to the extent that in a Malthusian regime it is strongly correlated with output per capita. Indeed, Chaney and Hornbeck (2015) provide evidence that early modern Spain was subjected to Malthusian dynamics after the Moriscos expulsion in 1609. Labor-scarce areas also gave rise to the creation of latifundia and shifts from grain to cash crops cultivation. An additional empirical problem is that it is impossible to 
distinguish which part of the effect of population density on current development works through political power concentration or the creation of large estates, or through other mechanisms such as agglomeration economies or technological progress à la Boserup.

The consistency between these alternative potential mechanisms and the observed timing of the effect of the Reconquest is theoretically less compelling than the case of the channel of structural inequality. Indeed, if the lack of agglomeration economies due to low population density, human capital depreciation derived from the expulsion of the Muslims, market fragmentation, and differences in religiosity were relevant factors explaining the effect of the Reconquest, the timing of the effect should have been much earlier, instead of much later during industrialization.

\subsection{Empirical Analysis}

Although the timing of the effect of the Reconquest provides some clues about the empirical validity of the proposed channels, we next analyze this question more systematically. For a variable to be a candidate for a channel, it needs to be correlated not only with the rate of Reconquest, but also with log GDP per capita. In addition, the effect of the rate of Reconquest needs to work via that particular channel. This is implemented through a 2SLS analysis that uses the rate of Reconquest to predict the channel variable in the first stage, and then regresses log GDP per capita in 2005 on the predicted channel variable, in both stages controlling for the baseline control set. The first and second stages are presented in Panel B and A of Table 7, respectively. Panel C reports the OLS regression of GDP per capita on the channel variable, which enables us to determine whether the selected channels have a large explanatory power for explaining current output levels, as occurred with rate of Reconquest in the reduced-form estimations. It should be pointed out that, strictly speaking, this 2SLS analysis does not represent an instrumental variables estimation.

As shown in Panel B, rate of Reconquest is positively correlated at conventional significance levels with the sources of structural inequality: land inequality as measured by the percentage of landless workers in 1797 and 1956, and the concentration of political power in the hands of the nobility as measured by noble jurisdictions in 1787. This is consistent with the fact that the faster a territory was reconquered, the more likely it was that the nobility was granted large estates and jurisdictional rights. Besides this channel, there is also evidence that a greater rate of Reconquest is significantly associated with a lower prevalence of population entities under the jurisdiction of the Church. This is because the concentration of economic and political power did not move hand in hand for the Church and the nobility. As widely documented in Spanish historiography, the clergy was important 
during the first two centuries of the Reconquest, whereas in the later stages of the Reconquest this power shifted to the nobility and military orders. This explains why the contribution of the Church to the repopulation of southern Spain was marginal compared to that of the other powerful groups. The reason for this must be sought in the opposition of the nobility to the acquisition of jurisdictional rights by the Church, because of the greater involvement of the former in the occupation and defense of frontier lands (Artola et al., 1978).

The second stage in Panel A shows that higher land inequality and a more unequal distribution of jurisdictional rights in the hands of the nobility are associated with lower current development. In addition, church jurisdiction is positively correlated with current GDP, which might be explained by the positive impact the Church may have had on the early spread of literacy. However, when we regress the literacy rate in 1860 on the percentage of population entities under church jurisdiction, after controlling for our baseline control set, there is no evidence to support the existence of a statistically significant positive link between both variables.

If we add to this the fact that i) there is no statistically significant relationship between church jurisdiction and GDP per capita in 2005 in the OLS regressions in Panel $\mathrm{C}^{48}$ and ii) the other religiosity indicator (percentage of population that was a member of the clergy) does not enter significantly in any of the estimation stages, we can to some extent rule out the empirical validity of the religiosity channel. Table 7 also provides consistent evidence across both estimation stages that other channels such as stem family prevalence, Moorish ancestry or historical road density are statistically insignificant. With the evidence at hand, this suggests that the traditional family type, the degree of integration of the Muslim population or their higher human capital concerning the level of agricultural technology, and market fragmentation are not relevant mechanisms explaining the long-term economic consequences of the Reconquest. In contrast, structural inequality, caused by high inequality in the access to a historical production factor like land and a high concentration of political power in the hands of the landowning nobility, appears to be the dominant channel through which the Reconquest affected current development.

[Insert Table 7 about here]

\subsection{Outcome Indicators at the Onset of Industrialization}

\footnotetext{
48 In contrast, the partial $\mathrm{R}^{2}$ of the structural inequality measures $(0.23$ for landless workers in $1797,0.45$ for landless workers in 1956 and 0.29 for noble jurisdictions) is comparable to the partial $\mathrm{R}^{2}$ of rate of Reconquest (Table 2, column 1), which equals 0.35 .
} 
The evidence presented in this section largely supports the view that structural inequality plays a central role in explaining the Reconquest's effect and why it became apparent during the era of industrialization. Table 8 provides additional evidence consistent with this hypothesis by focusing on the decisive moment in which Spain began industrializing. It is expected that some of the fundamentals of modern economic growth needed for industrialization to succeed were also undermined at the onset of the industrialization period. This is because such factors as a deficient education and health care precluded the broad majority of the population from participating in economic activity in those regions with an unequal distribution of land and political power.

Our dependent variables are a number of factors that are relevant for economic growth, all measured in the 1860s. They are two indicators related to education (literacy rate and school enrollment), two related to health (infant mortality and life expectancy), two associated with political participation (percentage of electors and voters), and two indicators related to social conflict (criminality and convicts). According to our view, we expect the rate of Reconquest -working through structural inequality- to lead to lower human capital (negatively affecting education and health), lower political participation, and higher social conflict. ${ }^{49}$ This is precisely what we observe in Panel A of Table 8 that presents a 2SLS analysis that traces the effect of the rate of Reconquest on outcomes in 1860 through the channel of structural inequality measured via our preferred indicator given by the percentage of landless workers in 1797. Similar results are obtained with the OLS estimates of the reduced-form effect of the rate of Reconquest on outcomes in 1860 (Panel B of Table 8). ${ }^{50}$ All in all, the evidence provided in Table 8 indicates that around 1860 historically rooted inequality had already created the conditions for the subsequent failure to industrialize.

\section{[Insert Table 8 about here]}

\section{Conclusions}

The legacy of history appears particularly pervasive in the case of Spain. This paper shows the Reconquest in the Middle Ages to have been a major historical process shaping the distribution of regional income. The rate of Reconquest, which captures the magnitude of the colonization effort required in the period when each one of what are now today's

\footnotetext{
${ }^{49}$ Regarding political participation, it is important to note that at that time a limited suffrage system based on capacity and fiscal criteria was in place.

${ }^{50}$ The negative impact of a low level of human capital appears in line with the evidence provided by Maloney and Valencia (2014) on the lack of technical capacity of former Spanish colonies at the time of industrialization, which emanate from the deficient technological capacity in the metropolis. They could also reflect inherited cultural and institutional factors, intrinsic to peninsular society organization.
} 
provinces was conquered by the Christians, has a robust and strong negative effect on current income. Our results are robust to controlling for historical controls and a wide array of climatic, geographic and natural resource endowments that account for simple and sophisticated versions of the geography hypothesis. Of particular interest is the lack of a significant effect due to differences in land suitability for plantation crops featuring economies of scale in production. Moreover, the effect of the rate of Reconquest survives the inclusion of latitude, log distances from key industrial centers, and several other methods to deal with the North-South gradient issue. The results also remain unaltered when employing several alternative indicators of the Reconquest. A municipality-level analysis that includes province-level fixed effects also provides evidence supporting the existence of a negative effect of the rate of Reconquest on economic development. In addition, a number of falsification tests indicate that the rate of Reconquest is not associated with indicators of pre-Reconquest economic development.

We argue that a rapid rate of Reconquest led to imperfect colonization, mainly characterized by a high concentration of power in a few hands. The evidence supports the view that a fast frontier expansion favored a political equilibrium biased toward the military elite (i.e., the nobility), which generated a high concentration of economic and political power, thus creating the conditions that led to the exclusion of large segments of the population from participating in the economic opportunities that opened up with the arrival of industrialization. The result was that provinces featuring an unequal distribution of economic and political power fell behind during the industrialization period. Thus, the Reconquest set in motion processes that generated persistent inequality, constituting a severe impediment to the requirements for modern economic growth, which is based on entrepreneurship, innovation, and the participation in economic activity of broad segments of the population.

Our results contribute to the novel literature on the political-economic effects of frontier expansions in that the existence of a large frontier that needs to be occupied and defended from the enemy may lead to a shift in the balance of power toward dominant groups, which may create the conditions for an inegalitarian society, with negative consequences for longterm development. This study of the Spanish Reconquest is also appealing from the point of view of the literature on colonialism, because it gives clues about the colonization of the New World. When Spain colonized Central and South America in the sixteenth century, it had the long experience gathered in the Reconquest. The policy of distributing economic power in the form of large estates, as well as of political power in the form of feudal rights, 
as applied in Spain since the mid-eleventh century (becoming widespread as of the thirteenth century) is a foretaste of what would later be implemented in the New World.

Finally, a question that deserves further research is why the effect of the Reconquest resulting from the pattern of colonization of the conquered lands is so persistent, even though today some sources of this problem are no longer present. The early obstruction of industrialization may have long-lasting consequences. Historical, economic, and political inequality may have affected the initial paths of industrialization and development and, once launched, different economic forces (e.g., increasing returns) reproduce the initial divergence. In addition, many social and cultural patterns developed in the past due to a high concentration of economic and political power may still persist today.

\section{References}

Acemoglu, Daron, Maria Angelica Bautista, Pablo Querubin, and James A. Robinson. 2008. "Economic and Political Inequality in Development: The Case of Cundinamarca, Colombia." In Institutions and Economic Performance, edited by Elhanan Helpman. Cambridge, MA: Harvard University Press.

Acemoglu, Daron, Davide Cantoni, Simon Johnson, and James A. Robinson. 2011. "The Consequences of Radical Reform: The French Revolution". American Economic Review 101: 3286-3307

Acemoglu, Daron, Simon Johnson, and James A. Robinson. 2001. "The Colonial Origins of Comparative Development: An Empirical Investigation." American Economic Review 91: 1369-1401.

Acemoglu, Daron, Simon Johnson, and James A. Robinson. 2002. "Reversal of Fortune: Geography and Institutions in the Making of the Modern World Income Distribution." Quarterly Journal of Economics 117 (4): 1231-1294.

Adams, Susan M., et al. 2008. "The Genetic Legacy of Religious Diversity and Intolerance: Paternal Lineages of Christians, Jews, and Muslims in the Iberian Peninsula." The American Journal of Human Genetics 83: 725-736.

Agencia Estatal de Meteorología. 2012. Valores climatológicos normales. (http://www.aemet.es/es/serviciosclimaticos/datosclimatologicos/ valoresclimatologicos).

Allen, Treb. 2015. "The Promise of Freedom: Fertility Decisions and the Escape from Slavery." Review of Economics and Statistics 97 (2): 472-484.

Alvarez-Palenzuela, Vicente A. 2002. "Enrique, Infante de Aragón, Maestre de Santiago." Medievalismo: Revista de la Sociedad Española de Estudios Medievales 12 (12): 37-89.

Alsan, Marcella. 2015. "The Effect of the Tse Tse Fly on African Development". American Economic Review, 105(1): 382-410. 
Angeles, Luis. 2007. "Income Inequality and Colonialism”, European Economic Review 51(5), 1155-1176.

Artola, Miguel, Antonio M. Bernal and J. Contreras. 1978. El Latifundio. Propiedad y Explotación ss. XVIII-XX. Madrid: Servicio de Publicaciones Agrarias.

Ashraf, Quamrul, and Galor Oded. 2013. "The 'Out of Africa' Hypothesis, Human Genetic Diversity, and Comparative Economic Development". American Economic Review 103: 146.

Banerjee, Abhijit, and Lakshmi Iyer. 2005. "History, Institutions, and Economic Performance: The Legacy of Colonial Land Tenure Systems in India." American Economic Review 95: 1190-1213.

Bairoch, Paul. 1988. Cities and Economic Development: From the Dawn of History to the Present. Chicago, IL: University of Chicago Press.

Barciela, Carlos, Jesús Giráldez, and Inmaculada López. 2005. "Sector agrario y pesca." In: Carreras, Albert, and Xavier Tafunell (Eds.) Estadísticas Históricas de España. Siglos XIX$X X$, Fundación BBVA: Bilbao, pp. 245-356.

Baten, Joerg, and Hippe, Ralph. 2013. 'Keep Them Ignorant.' Did Inequality in Land Distribution Delay Regional Numeracy Development?, London School of Economics Working Paper, London.

Baten, Joerg, and Jan Luiten van Zanden. 2008. "Book Production and the Onset of Modern Economic Growth". Journal of Economic Growth 13: 217-235.

Becker, Sascha O., and Ludger Woessmann. 2009. "Was Weber Wrong? A Human Capital Theory of Protestant Economic History." Quarterly Journal of Economics, 124 (2), 531596.

Bockstette,Valeri, Areendam Chanda, and Louis Putterman. 2002. "States and Markets: the Advantage of an Early Start". Journal of Economic Growth 7: 347-369.

Brenan, Geral. 1943. The Spanish Labyrinth: An Account of the Social and Political Background of the Spanish Civil War. Cambridge: Cambridge University Press.

Bruhn, Miriam, and Francisco A. Gallego. 2012. "Good, Bad, and Ugly Colonial Activities: Do They Matter for Economic Development?” Review of Economics and Statistics 94 (2): 433-461.

Burns, Robert I. 1989. "The Significance of the Frontier in the Middle Ages". In Medieval Frontier Societies, edited by Robert Bartlett and Angus Mackay, pp. 307-30. Clarendon Press: Oxford.

Cabrera Muñoz, Emilio. 1989. "The Medieval Origins of the Great Landed Estates of the Guadalquivir Valley". Economic History Review 42 (4): 465-483.

Cabrera Muñoz, Emilio. 2006. "Feudalismo y Señoríos en Andalucía (Siglos XIII al XV)." In Historia de Andalucía IV: El Nacimiento de Andalucía, pp. 106-134, edited by Manuel González Jiménez. Planeta Editorial: Barcelona. 
Carreras, Albert. 2005. "Industria", In: Carreras, Albert, and Xavier Tafunell (Eds.) Estadísticas Históricas de España. Siglos XIX-XX, Fundación BBVA: Bilbao, pp. 357-453.

Carreras, Albert, Leandro Prados de la Escosura, and Joan R. Rosés. 2005. "Renta y riqueza", In: Carreras, Albert, and Xavier Tafunell (Eds.) Estadísticas Históricas de España. Siglos XIX-XX, Fundación BBVA: Bilbao, pp. 1297-1376.

Carrión, Pascual. 1975. Los Latifundios en España. Su importancia, Origen. Consecuencias y Solución. Barcelona: Ariel.

Casado Alonso, Hilario. 2002. "La Economía en las Españas Medievales (c. $1000-c$. 1450).” In Historia económica de España: siglos $X-X X$, edited by Comín, Francisco, Mauro Hernández and Enrique Llopis, Chapter 1, 13-50. Barcelona: Crítica, D.L.

Chaney, Eric. 2008. "Ethnic Cleansing and the Long-term Persistence of Extractive Institutions: Evidence from the Expulsion of the Moriscos". Harvard University Working Paper.

Chaney, Eric. 2013. "Revolt on the Nile: Economic Shocks, Religion, and Political Power." Econometrica 81 (5): 2033-2053.

Chaney, Eric, and Hornbeck, Richard. 2015. "Economic Dynamics in the Malthusian Era: Evidence from the 1609 Spanish Expulsion of the Moriscos". Economic Journal, forthcoming.

Chejne, Anwar G. 1999. Historia de España Musulmana. Madrid: Cátedra, D.L.

Cinnirella, Francesco, and Hornung, Erik, 2013. Landownership concentration and the Expansion of Education. Ifo Institute Working Paper, Munich, Germany.

Cook, Justin C. 2014. "The Role of Lactase Persistence in Precolonial Development." Journal of Economic Growth 19: 369-406.

Davidson, Russell, and MacKinnon, James G. 1993. Estimation and Inference in Econometrics, Oxford: Oxford University Press.

Dell, Melissa. 2010. "The Persistent Effects of Peru's Mining Mita". Econometrica 78 (6): 1863-1903.

de Vries, Jan. 1976. The Economy of Europe in an Age of Crisis, 1600-1750. Cambridge, UK: Cambridge University Press.

Digital Atlas of Roman and Medieval Civilizations. Version 1.1. Bishoprics ca. 600 (available at: http://darmc.harvard.edu/icb/icb.do?keyword=k40248\&pageid=icb.page188865).

Dittmar, Jeremiah E. 2011. Information Technology and Economic Change: The Impact of the Printing Press. Quarterly Journal of Economics, 126, 1133-1172.

Doepke, Matthias, and Zilibotti, Fabrizio. 2008. Occupational Choice and the Spirit of Capitalism. Quarterly Journal of Economics, 123 (2), 747-793. 
Domenech, Jordi. 2012. Rural Labour Markets and Rural Conflict in Spain before the Civil War (1931-1936). Working Papers in Economic History WP 12-01, Universidad Carlos III de Madrid.

Domenech, Jordi. 2015. Land Tenure Inequality, Harvests, and Rural Conflict: Evidence from Southern Spain during the Second Republic (1931-1934). Social Science History, 39 (2), 253-286.

Domínguez-Ortiz, Antonio. 1955. La Sociedad Española en el Siglo XVIII. Madrid: Consejo Superior de Investigaciones Científicas, Instituto Balmes de Sociología.

Droller, Federico. 2013. Migration, Population Composition and Long-run Economic Development: Evidence from Settlements in the Pampas. Mimeograph, University of Santiago de Chile.

Easterly, William, and Ross Levine. 2003. "Tropics, Germs, and Crops: How Endowments Influence Economic Development”. Journal of Monetary Economics 50, 3-39.

Easterly, William, and Ross Levine. 2016. "The European Origins of Economic Development". Journal of Economic Growth, forthcoming.

Engerman, Stanley L., and Kenneth L. Sokoloff. 2000. "Institutions, Factor Endowments, and Paths of Development in the New World." Journal of Economic Perspectives 14 (3): $217-232$.

Engerman, Stanley L., and Kenneth L. Sokoloff. 2002. "Factor Endowments, Inequality, and Paths of Development among New World Economies." Economia 3(1): 41-109.

Erdozáin, Pilar, and Mikelarena, Fernando. 1999. "Las cifras de activos agrarios de los censos de población española del período 1877-1991: un análisis crítico", Revista de Demografía Histórica, Vol. 17 (1): 89-11.

FAO/IIASA. 2010. Global Agro-ecological Zones (GAEZ v3.0). FAO, Rome, Italy and IIASA, Laxenburg, Austria.

Fenske, James (2013). "Does Land Abundance Explain African Institutions?" Economic Journal, 123 (573), 1363-1390.

Fenske, James. 2014. "Ecology, Trade and States in Precolonial Africa." Journal of European Economic Association, 12 (3): 612-640.

Feyrer, James, and Bruce Sacerdote. 2009. "Colonialism and Modern Income: Islands as Natural Experiments." Review of Economics and Statistics 91(2): 245-262.

Fischer, G., F. Nachtergaele, S. Prieler, H.T. van Velthuizen, L. Verelst, D. Wiberg. 2008. Global Agro-ecological Zones Assessment for Agriculture (GAEZ 2008). IIASA, Laxenburg, Austria and FAO, Rome, Italy.

Forey, Alan J. 1984. "The Military Orders and the Spanish Reconquest in the Twelfth and Thirteenth Centuries”. Traditio 40: 197-234. 
Frankema, Ewout. 2010. "The Colonial Roots of Land Inequality: Geography, Factor Endowments, or Institutions?” Economic History Review 63 (2): 418-451

Gallego, F.A., 2010. "Historical Origins of Schooling: The Role of Democracy and Political Decentralization". Review of Economics and Statistics 92 (2), 228-243.

Gallup, John L, Jeffrey D. Sachs, and Andrew D. Mellinger. 1999. "Geography and Economic Development.” International Regional Science Review 22: 179-232.

Galor, Oded, and David Weil. 1996. "The Gender Gap, Fertility, and Growth." American Economic Review, 86(3): 374-387.

Galor, Oded, and Omer, Moav. 2002. "Natural Selection and the Origin of Economic Growth.” Quarterly Journal of Economics, 117: 1133-1191.

Galor, Oded, Omer Moav, and Dietrich Vollrath. 2009. "Inequality in Land Ownership, the Emergence of Human Capital Promoting Institutions and the Great Divergence." Review of Economic Studies 76: 143-179.

García Barbancho, Alfonso. 1954. "La población, la superficie y la producción agrícola como determinantes de las zonas de cultivo intensivo y extensivo", Revista de Estudios Agrosociales, 9, págs. 17-30.

García de Cortázar, Fernando. 2007. Historia de España Menéndez Pidal. Apéndice. Madrid : Espasa Calpe.

García-Jimeno, Camilo, and James A. Robinson (2011). "The Myth of the Frontier." In: Dora L. Costa and Naomi R. Lamoreaux (Eds.), Understanding Long-Run Economic Growth. University of Chicago Press, Chicago, pp. 49-88.

García-Ormaechea, Rafael. 2002. Supervivencias Feudales en España. Estudio de Legislación y Jurisprudencia sobre Señoríos. Pamplona: Urgoiti Editores.

Gennaioli, Nicola, and Ilia Rainer. 2007. “The Modern Impact of Precolonial Centralization in Africa." Journal of Economic Growth 12 (3), 185-234.

Gennaioli, Nicola, Rafael Laporta, Florencio Lopez-de Silanes, and Shleifer, Andrei. 2013. "Human Capital and Regional Development." Quarterly Journal of Economics 128 (1): 105-164.

Gennaioli, Nicola, La Porta, Rafael, López de Silanes, Florencio, and Andrei Shleifer. (2014). "Growth in Regions." Journal of Economic Growth, 19, 259-309.

Glick, Thomas F. 1979. Islamic and Christian Spain in the early Middle Ages. Princeton: Princeton University Press.

González Jiménez, Manuel. 1989. Frontier and Settlement in the Kingdom of Castile (10851350). In Medieval Frontier Societies, edited by Robert Bartlett and Angus MacKay, pp. 4974. Clarendon Press: Oxford.

González Jiménez, Manuel. 2006. Orígenes de la Andalucía Cristiana: La Repoblación de Andalucía en el Siglo XIII, in Historia de Andalucía II: La Andalucía Dividida (1301- 
1350), edited by Manuel González Jiménez and José Enrique López de Coca Castañer, pp. 151-182, Editorial Planeta: Barcelona.

Grafe, Regina. 2012. Distant Tyranny: Markets, Power, and Backwardness in Spain, 16501800. Princeton University Press: Princeton.

Guichard, Pierre. 2002. De la Expansión Árabe a la Reconquista: Esplendor y Fragilidad de Al-Andalus. Granada: Ed. Fundación El Legado Andalusí.

Hansen Casper W., Peter S. Jensen, and Skovsgaard, Christian V. 2015. Modern gender roles and agricultural history: the Neolithic inheritance, Journal of Economic Growth, 20 (4), 365-404.

Hennessy, C. Alistair M. (1978). The Frontier in Latin American History. London: Edward Arnold.

Herr, Richard. 1958. The Eighteenth-Century Revolution in Spain. Princeton, New Jersey: Princeton University Press.

Herr, Richard. 1974. "El Significado de la Desamortización en España.” Moneda y Crédito, $131,55-94$.

Hijmans, Robert J., Susan E. Cameron, Juan L. Parra, Peter G. Jones and Andy Jarvis. 2005. Very high resolution interpolated climate surfaces for global land areas. International Journal of Climatology 25: 1965-1978.

Imbens, Guido W., and Michal Kolesar. 2012. Robust Standard Errors in Small Samples: Some Practical Advice. NBER Working Paper No. 18478. National Bureau of Economic Research.

IMF. 2013. International Financial Statistics Database. International Monetary Fund. Washington DC.

INE, 1987. Censo de 1787 “Floridablanca”. Madrid:Instituto Nacional de Estadística.

INE. 1992. Censo de la población de España de el año 1797 : executado de orden del Rey en el de 1801. Madrid : Instituto Nacional de Estadística.

Instituto Geográfico Nacional. 2008. Atlas Nacional de España. (http://www.ign.es/ane/ane1986-2008/).

Instituto Geográfico Nacional, 2012. Nomenclátor Geográfico de Municipios y Entidades de Población. Available at http://www.ign.es/.

Iyer, Lakshmi. 2010. "Direct versus indirect colonial rule in India: Long-term consequences." Review of Economics and Statistics 92 (4): 693-713.

Jeanty, Pierre W. 2012. "Stata Implementation of the Non-Parametric Spatial Heteroskedasticity and Autocorrelation Consistent Covariance Matrix Estimator", Stata Conference San Diego, July 26-27, 2012.

Junta General de Estadística. 1863a. Anuario Estadístico de España 1860-1861. Imprenta Nacional: Madrid. 
Junta General de Estadística. 1863b. Censo de la Población de España 1860. Imprenta Nacional: Madrid.

Junta General de Estadística. 1865. Anuario Estadístico de España 1862-1865. Imprenta Nacional: Madrid.

Junta Nacional de Hermandades (1959). "Encuesta agropecuaria: 1956" . Revista Sindical de Estadística. 1959. (53) pp. 4-5.

López-González, Clemente, Elena Postigo Castellano, and José Ignacio Ruiz Rodríguez. 1989. "Las Ordenes Militares Castellanas en la Época Moderna: Una Aproximación Cartográfica" in Las Ordenes Militares en el Mediterráneo Occidental. Siglos XIII-XVIII, edited by Manuel Espadas Burgos and Didier Ozanam, pp. 291-303. Casa de Velázquez, Instituto de Estudios Manchegos. Imprenta Taravilla: Toledo.

Malefakis, Edward. 1970. Agrarian Reform and Peasant Revolution in Spain. Origins of the Civil War. New Haven: Yale University Press.

Maloney, William F., and Valencia, Felipe. 2014. Engineers, Innovative Capacity and Development in the Americas, World Bank Policy Research Working Paper no. 6814, The World Bank, Washington D.C.

Mestre-Campi, Jesús, and Flocel Sabaté. 1998. Atlas de la "Reconquista". La Frontera Peninsular entre los Siglos VIII y XV. Barcelona: Ediciones Península.

Mitchell, Brian R. 2007a. International Historical Statistics. Europe, 1750-2005. Palgrave: Hampshire.

Mitchell, Brian R. 2007b. International Historical Statistics. The Americas, 1750-2005. Palgrave: Hampshire.

Morales, Antonio. 1998. Las Bases Politicas, Económicas y Sociales de un Régimen en Transformación (1759-1834). Madrid: Espasa Calpe.

Nadal, Jordi (1997). El Fracaso de la Revolución Industrial en España, 1814-1913. Ariel, Barcelona.

Nadal, J., Carreras, A., and Sudriá, C. (1987). La Economía Española del Siglo XX. Una Perspectiva Histórica. Barcelona, Ariel.

Nunn, Nathan. 2014. "Historical Development," In: Handbook of Economic Growth. Vol. 2. Chapter 7, Edited by Philippe Aghion and Peter Durlauf, North-Holland, pp. 347-402.

Núñez, Clara E. 1992. La Fuente de la Riqueza: Educación y Desarrollo Económico en la España Contemporánea. Madrid: Alianza.

Olsson, Ola, and Christopher Paik. 2013. "A Western Reversal since the Neolithic? The Long-run Impact of Early Agriculture.” Working Paper, Gothenburg University.

Oto-Peralías, Daniel, and Diego Romero-Ávila. 2016. "Historical Frontiers and the Rise of Inequality. The Case of the Frontier of Granada". Journal of European Economic Association, forthcoming. 
Pascual, Pere, and Sudriá, Carles. 2002. "El Difícil Arranque de la Industrialización.” In Historia económica de España: Siglos $X-X X$, edited by Comín, Francisco, Mauro Hernández y Enrique Llopis, Chapter 6, 203-241. Barcelona: Crítica, D.L.

Pinhasi, Ron, Joaquim Fort, and Albert J. Ammerman (2005) "Tracing the Origins and Spread of Agriculture in Europe”. PLOS Biology 3(12): 2220-2228.

Pleiades. 2014. Ancient World Mapping Center and Institute for the Study of the Ancient World. http://pleiades.stoa.org/ Accessed on November 25, 2014.

Proyecto Nisal (2014). Niveles de vida Salud Alimentación. http://www.proyectonisal.org/.

Rosés, Joan R. 2006. "La Primera Etapa de la Industrialización.” In: Historia Económica de España, edited by Agustín Gonzalez Enciso and Juan M. Matés Barco, Chapter 7, 185-207. Barcelona: Ariel.

Rosés, Joan R., Julio Martínez-Galarraga, and Daniel A. Tirado. 2010. "The Upswing of Regional Income Inequality in Spain (1860-1930)". Explorations in Economic History 47: 244-257.

Ruiz-Maya, Luis. 1979. "Sobre el Origen Histórico de la Concentración de la Tierra: una Aproximación Estadística.” Agricultura y Sociedad 10: 9-103.

Sánchez Albornoz, Claudio. 1932. La Reforma Agraria ante la Historia. Madrid: Tipografía de Archivos.

Sachs, Jeffrey D. 2003. "Institutions don't Rule: Direct Effects of Geography on per Capita Income", NBER Working Paper. No. 9490. Cambridge, MA: National Bureau of Economic Research.

Sakalli, Seyhun O. 2014. Coexistence, Polarization, and Development: The Armenian Legacy in Modern Turkey. Mimeograph, Paris School of Economics.

Samii, Cyrus and Peter M Aronow. 2012. "On Equivalencies Between Design-Based and Regression-Based Variance Estimators for Randomized Experiments" Statistics and Probability Letters 82(2): 365-370.

Sobrequés. 1972. "La Baja Edad Media Peninsular." In Historia de España y América Social y Económica edited by J. Vicens-Vives. Barcelona: Ediciones Vicens-Vives.

Spolaore, Enrico and Roman Wacziarg. 2013. "How Deep Are the Roots of Economic Development?" Journal of Economic Literature 51 (2): 325-369.

Squicciarini, Mara P., and Voigtlander, Nico. 2015. "Human Capital and Industrialization: Evidence from the Age of Enlightenment." Quarterly Journal of Economics, 130 (4), 18251883.

Tedde de Lorca, Pedro. 1985. Sobre los Orígenes Históricos del Desarrollo Andaluz: Algunas Hipótesis, en La Modernización Económica de España, 1830-1930, edited by Nicolás Sánchez Albornoz, pp. 299-318, Alianza Editorial, Madrid. 
Tortellá, Gabriel. 2000. The Development of Modern Spain. An Economic History of the Nineteenth and Twentieth Centuries. Harvard University Press, Cambridge: MA.

Tur-Prats, Ana. 2015. "Family Types and Intimate-Partner Violence." Mimeograph, University Pompeu Fabra.

Turner, Frederick Jackson. 1920. The Frontier in American History. New York: H. Holt and Co.

Vicens Vives, Jaime. 1969. An Economic History of Spain. Princeton: Princeton University Press.

Vidal Robert, Jordi. 2014. "Long-run Effects of the Spanish Inquisition", CAGE Online Working Paper No. 192, Warwick University. 


\section{TABLES AND FIGURES IN THE MAIN TEXT}

TABLE 1 - THE EFFECT OF THE RECONQUEST ON CURRENT DEVELOPMENT

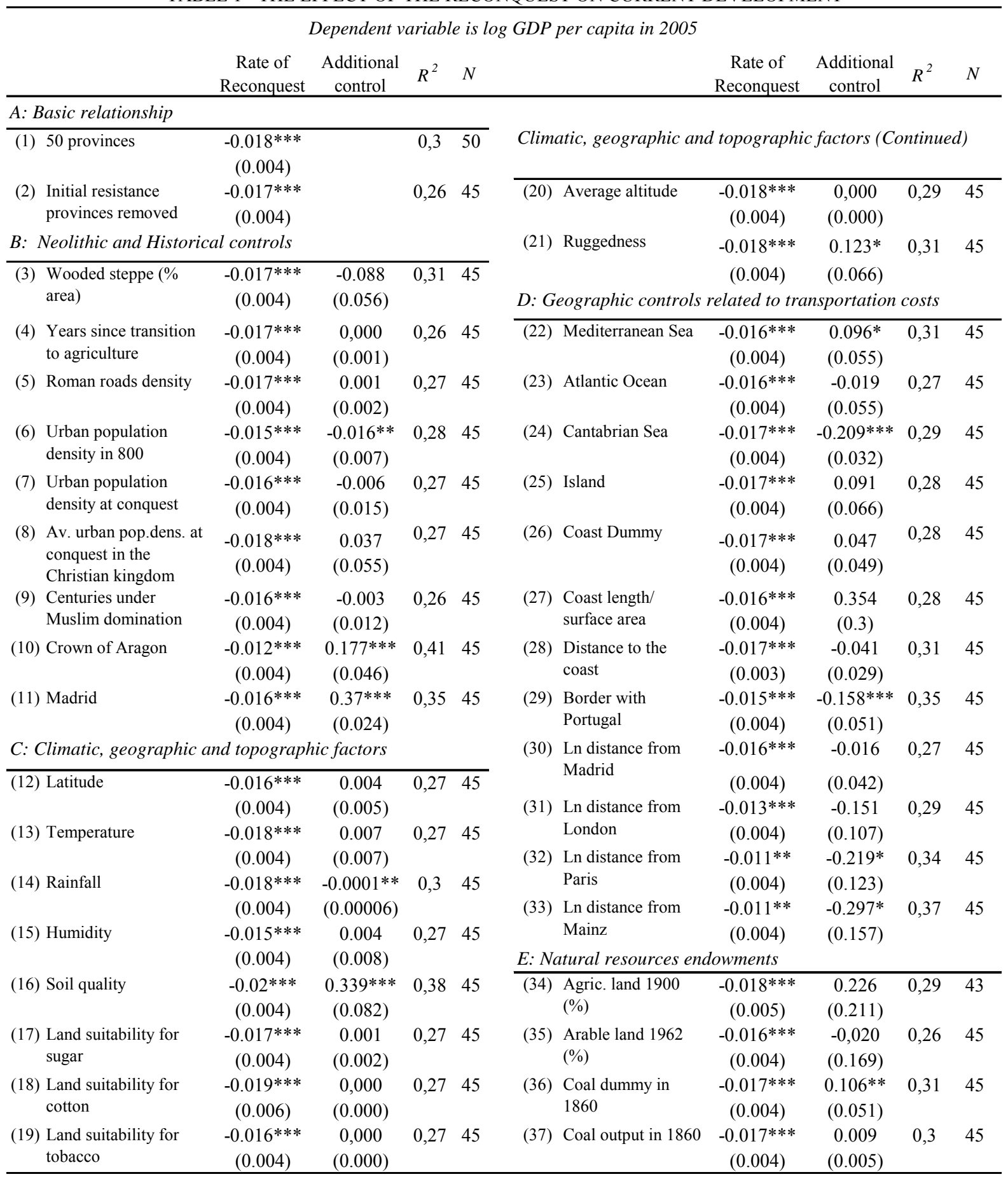

Notes: Variables descriptions are provided in Table 9. The estimations include a constant term, which is omitted for space considerations

Robust standard errors are in parentheses. ${ }^{*}, * *$ and ${ }^{* * *}$ denote significance at the 10,5 and $1 \%$ level, respectively. 


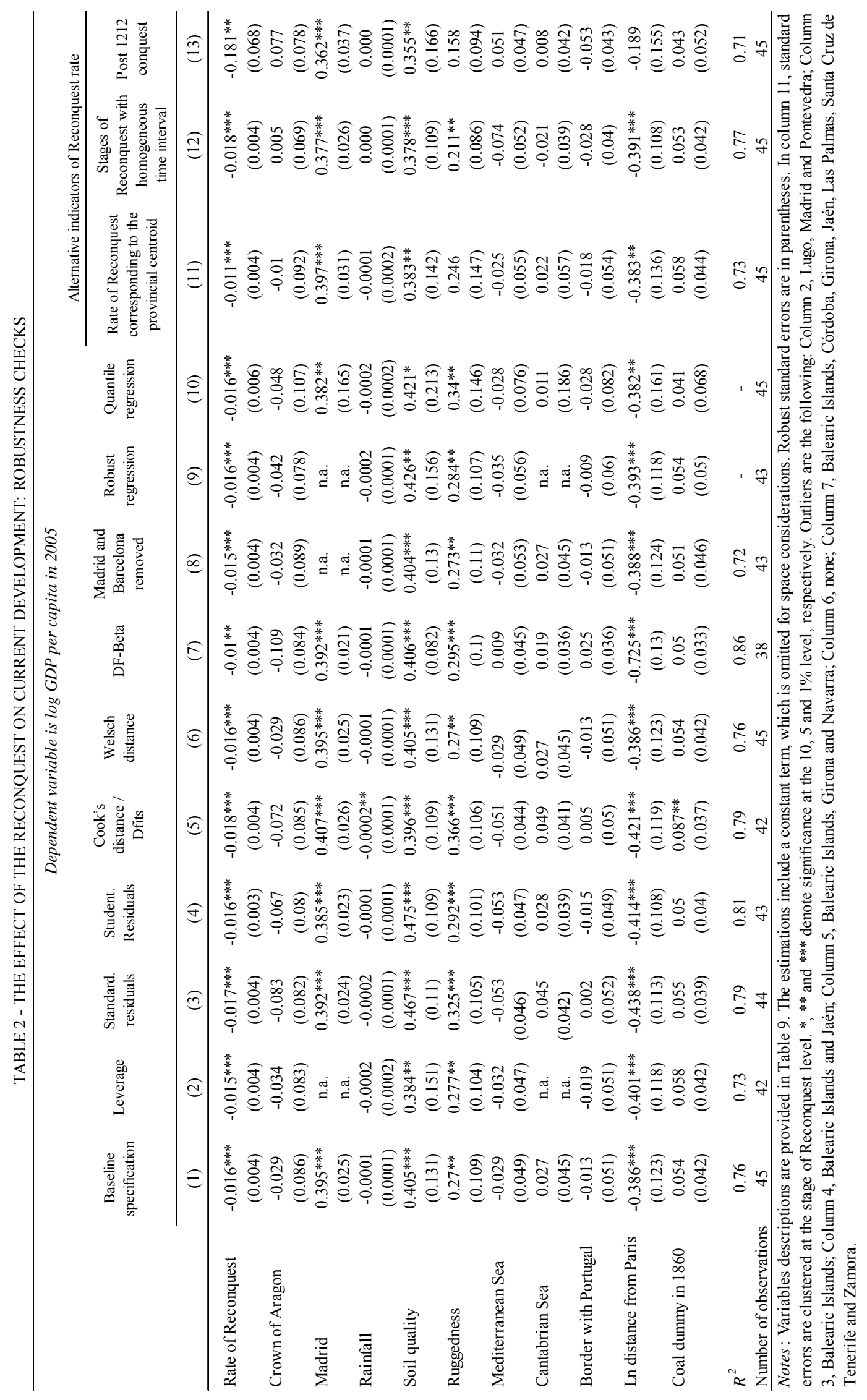




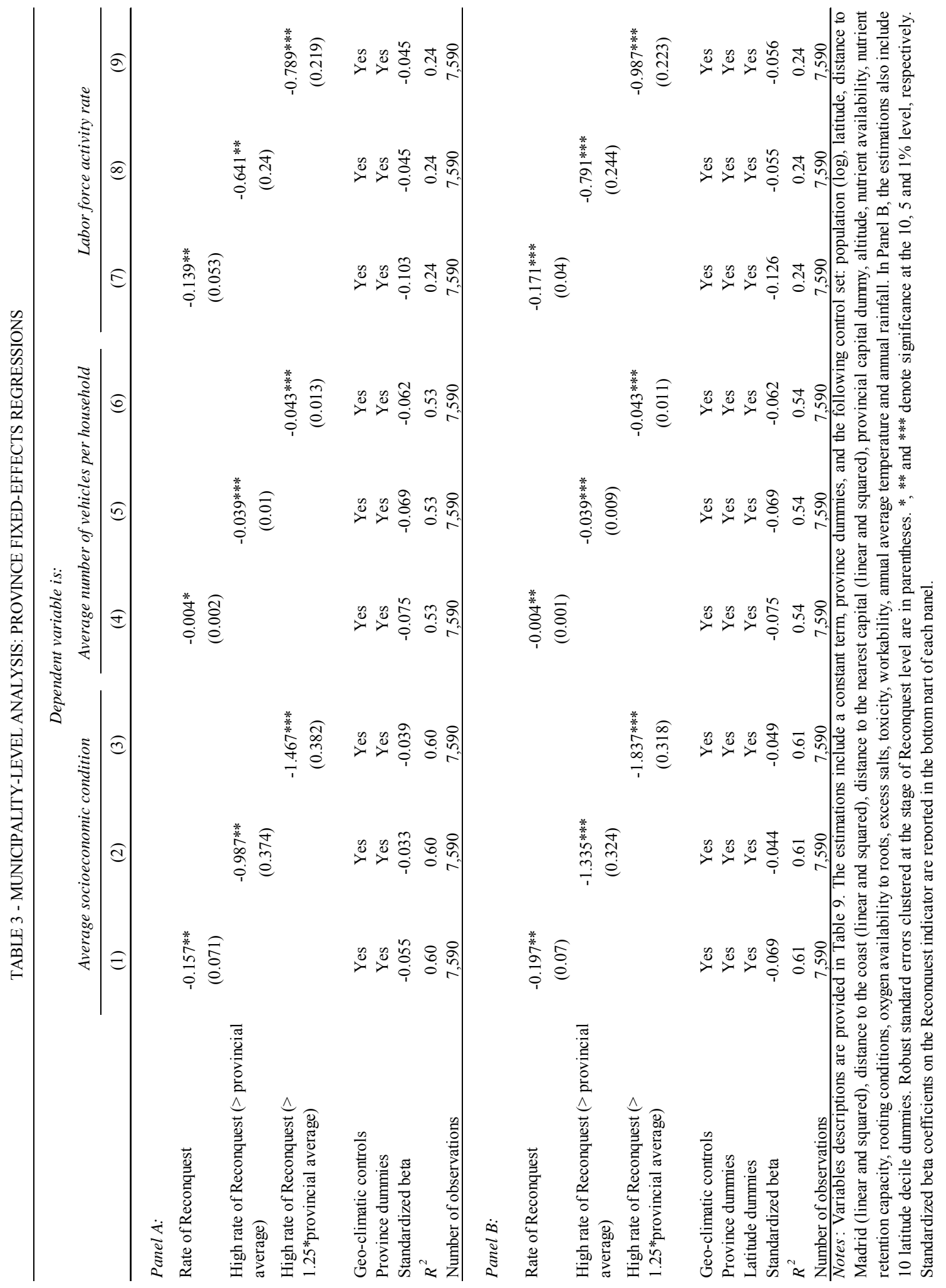




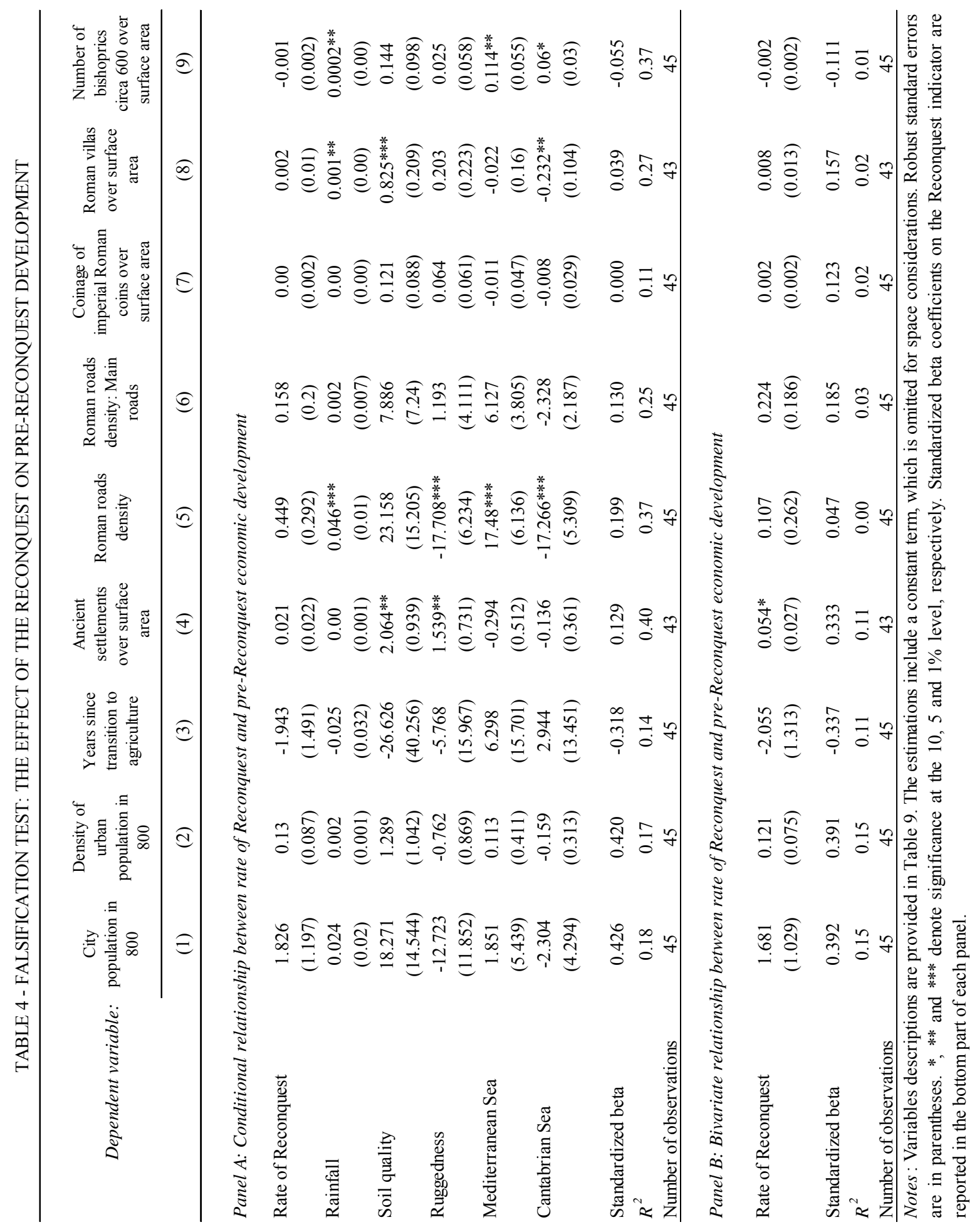




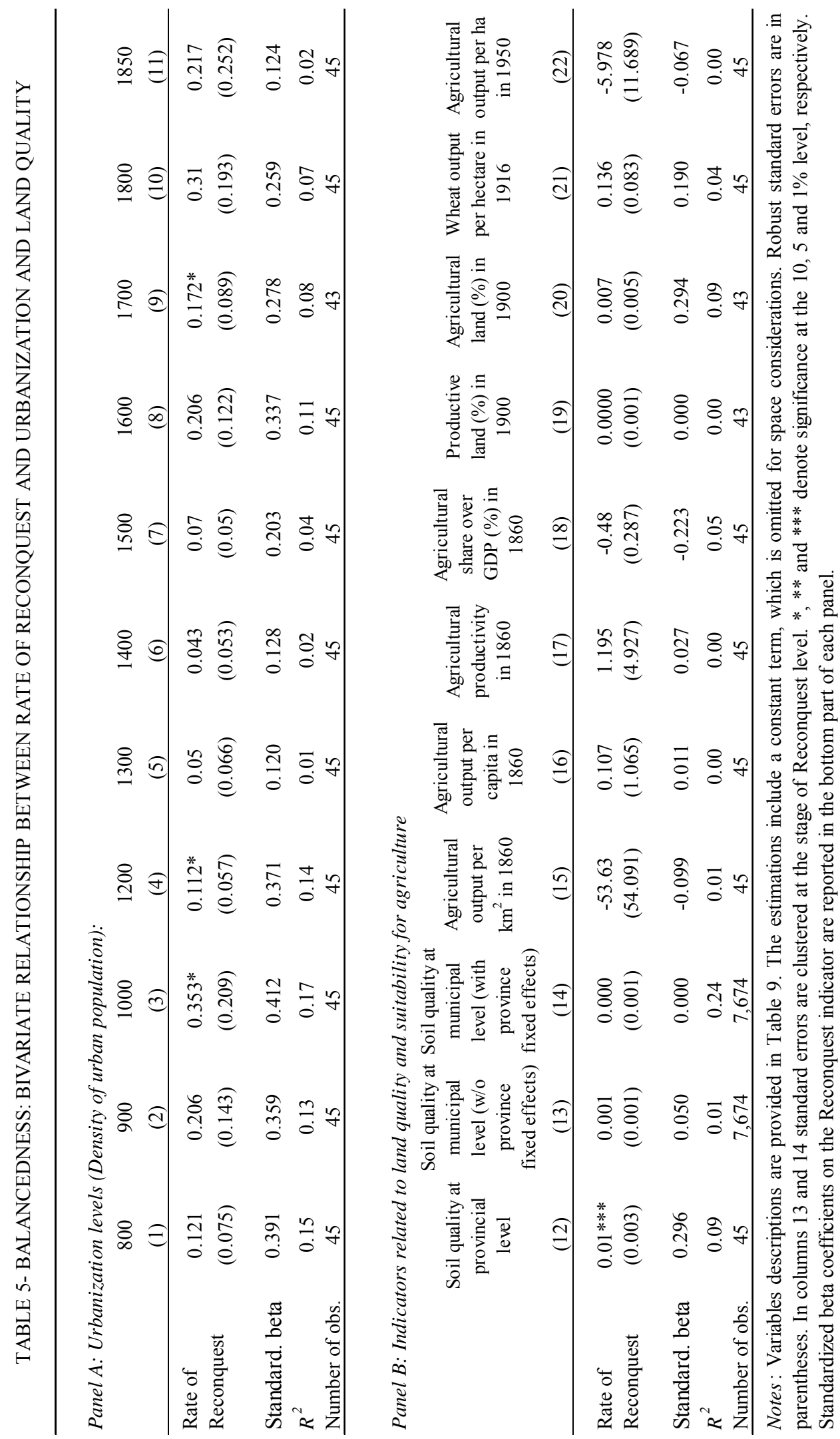




\begin{tabular}{|c|c|c|c|c|c|c|c|}
\hline \multicolumn{8}{|c|}{ Dependent variable is relative economic development } \\
\hline & (1) & (2) & (3) & (4) & $(5)$ & (6) & (7) \\
\hline Rate of Reconquest x 1500 & $\begin{array}{l}-5.909 \\
(3.714)\end{array}$ & $\begin{array}{l}-6.235 \\
(3.976)\end{array}$ & $\begin{array}{l}-6.003 \\
(3.775)\end{array}$ & $\begin{array}{l}-5.788 \\
(3.581)\end{array}$ & $\begin{array}{l}-5.977 \\
(3.731)\end{array}$ & $\begin{array}{c}-7.553^{*} \\
(4.243)\end{array}$ & $\begin{array}{l}-6.444 * \\
(3.711)\end{array}$ \\
\hline Rate of Reconquest x 1600 & $\begin{array}{l}-3.066 \\
(4.35)\end{array}$ & $\begin{array}{l}-3.506 \\
(4.553)\end{array}$ & $\begin{array}{l}-3.107 \\
(4.418)\end{array}$ & $\begin{array}{l}-2.959 \\
(4.221)\end{array}$ & $\begin{array}{l}-3.316 \\
(4.272)\end{array}$ & $\begin{array}{l}-3.354 \\
(4.75)\end{array}$ & $\begin{array}{l}-2.543 \\
(4.145)\end{array}$ \\
\hline Rate of Reconquest x 1700 & $\begin{array}{l}-2.969 \\
(3.963)\end{array}$ & $\begin{array}{l}-3.496 \\
(4.092)\end{array}$ & $\begin{array}{l}-2.994 \\
(4.023)\end{array}$ & $\begin{array}{l}-2.831 \\
(3.794)\end{array}$ & $\begin{array}{l}-3.078 \\
(3.984)\end{array}$ & $\begin{array}{l}-8.95^{* *} \\
(4.295)\end{array}$ & $\begin{array}{l}-8.67 * * \\
(3.799)\end{array}$ \\
\hline Rate of Reconquest x 1800 & $\begin{array}{l}-4.852 \\
(4.114)\end{array}$ & $\begin{array}{l}-5.531 \\
(4.296)\end{array}$ & $\begin{array}{l}-4.779 \\
(4.179)\end{array}$ & $\begin{array}{l}-4.764 \\
(4.07)\end{array}$ & $\begin{array}{l}-4.843 \\
(4.03)\end{array}$ & $\begin{array}{l}-7.169^{*} \\
(4.314)\end{array}$ & $\begin{array}{l}-6.383 * \\
(3.761)\end{array}$ \\
\hline Rate of Reconquest x 1860 & $\begin{array}{c}-8.772 * * \\
(4.219)\end{array}$ & $\begin{array}{c}-9.015^{* *} \\
(4.41)\end{array}$ & $\begin{array}{c}-8.807 * * \\
(4.283)\end{array}$ & $\begin{array}{c}-8.694 * * \\
(4.199)\end{array}$ & $\begin{array}{c}-8.985^{* *} \\
(4.272)\end{array}$ & $\begin{array}{c}-9.558^{* *} \\
(4.605)\end{array}$ & $\begin{array}{c}-8.992 * * \\
(4.209)\end{array}$ \\
\hline Rate of Reconquest x 1930 & $\begin{array}{c}-10.704 * * \\
(4.388)\end{array}$ & $\begin{array}{c}-10.602 * * \\
(4.587)\end{array}$ & $\begin{array}{c}-10.568^{* *} \\
(4.45)\end{array}$ & $\begin{array}{c}-10.647^{* *} \\
(4.359)\end{array}$ & $\begin{array}{c}-10.893 * * \\
(4.455)\end{array}$ & $\begin{array}{c}-10.729 * * \\
(4.876)\end{array}$ & $\begin{array}{c}-10.126^{* *} \\
(4.516)\end{array}$ \\
\hline Rate of Reconquest x 1971 & $\begin{array}{c}-11.427^{* *} \\
(4.432)\end{array}$ & $\begin{array}{c}-11.345^{* *} \\
(4.632)\end{array}$ & $\begin{array}{c}-11.333^{* *} \\
(4.498)\end{array}$ & $\begin{array}{c}-11.37^{* *} \\
(4.405)\end{array}$ & $\begin{array}{c}-11.65^{* *} \\
(4.523)\end{array}$ & $\begin{array}{c}-11.749 * * \\
(4.938)\end{array}$ & $\begin{array}{c}-11.222 * * \\
(4.623)\end{array}$ \\
\hline Rate of Reconquest x 2005 & $\begin{array}{c}-11.578 * * \\
(4.504)\end{array}$ & $\begin{array}{c}-11.392^{* *} \\
(4.709)\end{array}$ & $\begin{array}{c}-11.438^{* *} \\
(4.571)\end{array}$ & $\begin{array}{c}-11.517 * * \\
(4.483)\end{array}$ & $\begin{array}{c}-11.825^{* *} \\
(4.599)\end{array}$ & $\begin{array}{c}-11.809 * * \\
(4.989)\end{array}$ & $\begin{array}{c}-11.201 * * \\
(4.69)\end{array}$ \\
\hline Soil quality x 1500 & & $\begin{array}{c}31.948 \\
(54.612)\end{array}$ & & & & & $\begin{array}{c}25.517 \\
(62.613)\end{array}$ \\
\hline Soil quality x 1600 & & $\begin{array}{c}43.09 \\
(45.431)\end{array}$ & & & & & $\begin{array}{l}104.393 * \\
(55.469)\end{array}$ \\
\hline Soil quality x 1700 & & $\begin{array}{c}52.816 \\
(49.942)\end{array}$ & & & & & $\begin{array}{l}114.882 * \\
(64.916)\end{array}$ \\
\hline Soil quality x 1800 & & $\begin{array}{c}66.491 \\
(55.036)\end{array}$ & & & & & $\begin{array}{c}55.14 \\
(53.235)\end{array}$ \\
\hline Soil quality x 1860 & & $\begin{array}{c}23.808 \\
(37.686)\end{array}$ & & & & & $\begin{array}{l}57.826 \\
(42.02)\end{array}$ \\
\hline Soil quality x 1930 & & $\begin{array}{c}-9.987 \\
(42.224)\end{array}$ & & & & & $\begin{array}{c}41.931 \\
(44.843)\end{array}$ \\
\hline Soil quality x 1971 & & $\begin{array}{c}-8.008 \\
(48.579)\end{array}$ & & & & & $\begin{array}{c}39.03 \\
(46.537)\end{array}$ \\
\hline Soil quality x 2005 & & $\begin{array}{l}-18.209 \\
(47.651)\end{array}$ & & & & & $\begin{array}{c}37.29 \\
(46.223)\end{array}$ \\
\hline Cantabrian Sea x 1500 & & & $\begin{array}{c}-29.85 \\
(18.265)\end{array}$ & & & & $\begin{array}{c}-48.103 * * \\
(20.271)\end{array}$ \\
\hline Cantabrian Sea x 1600 & & & $\begin{array}{l}-12.993 \\
(17.259)\end{array}$ & & & & $\begin{array}{l}-18.857 \\
(20.639)\end{array}$ \\
\hline Cantabrian Sea x 1700 & & & $\begin{array}{c}-8.133 \\
(20.11)\end{array}$ & & & & $\begin{array}{c}-7.358 \\
(23.483)\end{array}$ \\
\hline Cantabrian Sea x 1800 & & & $\begin{array}{c}23.464 \\
(17.792)\end{array}$ & & & & $\begin{array}{c}34.465 \\
(23.214)\end{array}$ \\
\hline Cantabrian Sea x 1860 & & & $\begin{array}{l}-11.039 \\
(14.349)\end{array}$ & & & & $\begin{array}{c}-26.48 \\
(18.653)\end{array}$ \\
\hline Cantabrian Sea x 1930 & & & $\begin{array}{c}43.438 * * * \\
(14.651)\end{array}$ & & & & $\begin{array}{c}28.183 \\
(18.867)\end{array}$ \\
\hline Cantabrian Sea x 1971 & & & $\begin{array}{l}30.061^{*} \\
(16.008)\end{array}$ & & & & $\begin{array}{c}9.296 \\
(20.429)\end{array}$ \\
\hline Cantabrian Sea x 2005 & & & $\begin{array}{c}44.398 * * * \\
(16.756) \\
\end{array}$ & & & & $\begin{array}{c}19.369 \\
(20.179) \\
\end{array}$ \\
\hline
\end{tabular}


Dependent variable is relative economic development

\begin{tabular}{|c|c|c|c|c|c|c|c|}
\hline & $(1)$ & $(2)$ & (3) & (4) & (5) & (6) & (7) \\
\hline Coal dummy x 1500 & & & & $\begin{array}{c}-113.56^{*} \\
(64.287)\end{array}$ & & & $\begin{array}{r}-113.245 \\
(71.216)\end{array}$ \\
\hline Coal dummy x 1600 & & & & $\begin{array}{r}-100.617 \\
(69.542)\end{array}$ & & & $\begin{array}{r}-113.076 \\
(75.572)\end{array}$ \\
\hline Coal dummy x 1700 & & & & $\begin{array}{c}-121.453^{*} \\
(65.849)\end{array}$ & & & $\begin{array}{c}-99.208 \\
(75.383)\end{array}$ \\
\hline Coal dummy x 1800 & & & & $\begin{array}{c}-83.408 \\
(67.76)\end{array}$ & & & $\begin{array}{l}-73.803 \\
(71.808)\end{array}$ \\
\hline Coal dummy x 1860 & & & & $\begin{array}{l}-73.736 \\
(70.205)\end{array}$ & & & $\begin{array}{l}-77.859 \\
(76.87)\end{array}$ \\
\hline Coal dummy x 1930 & & & & $\begin{array}{c}-53.86 \\
(69.974)\end{array}$ & & & $\begin{array}{l}-60.038 \\
(77.255)\end{array}$ \\
\hline Coal dummy x 1971 & & & & $\begin{array}{l}-54.326 \\
(72.032)\end{array}$ & & & $\begin{array}{c}-58.63 \\
(78.675)\end{array}$ \\
\hline Coal dummy x 2005 & & & & $\begin{array}{l}-57.369 \\
(73.097)\end{array}$ & & & $\begin{array}{l}-62.378 \\
(79.222)\end{array}$ \\
\hline Medit. Sea x 1500 & & & & & $\begin{array}{l}-31.845 \\
(39.245)\end{array}$ & & $\begin{array}{l}-34.051 \\
(40.195)\end{array}$ \\
\hline Medit. Sea x 1600 & & & & & $\begin{array}{c}-116.079 * * * \\
(34.231)\end{array}$ & & $\begin{array}{c}-123.746^{* * * *} \\
(36.126)\end{array}$ \\
\hline Medit. Sea x 1700 & & & & & $\begin{array}{c}-50.973 \\
(38.892)\end{array}$ & & $\begin{array}{l}-67.883 * \\
(40.737)\end{array}$ \\
\hline Medit. Sea x 1800 & & & & & $\begin{array}{c}4.312 \\
(39.13)\end{array}$ & & $\begin{array}{c}3.466 \\
(41.477)\end{array}$ \\
\hline Medit. Sea x 1860 & & & & & $\begin{array}{c}-98.873 * * * \\
(31.005)\end{array}$ & & $\begin{array}{c}-103.19 * * * \\
(31.858)\end{array}$ \\
\hline Medit. Sea x 1930 & & & & & $\begin{array}{c}-87.314^{* *} \\
(35.455)\end{array}$ & & $\begin{array}{c}-89.485^{* *} \\
(35.861)\end{array}$ \\
\hline Medit. Sea x 1971 & & & & & $\begin{array}{c}-103.266^{* * *} \\
(37.208)\end{array}$ & & $\begin{array}{c}-105.595^{* * * *} \\
(37.917)\end{array}$ \\
\hline Medit. Sea x 2005 & & & & & $\begin{array}{c}-114.678^{* * *} \\
(37.632)\end{array}$ & & $\begin{array}{c}-116.691 * * * \\
(38.301)\end{array}$ \\
\hline Log distance to Paris $\mathrm{x} 1500$ & & & & & & $\begin{array}{c}68.031 \\
(65.059)\end{array}$ & $\begin{array}{c}7.019 \\
(65.007)\end{array}$ \\
\hline Log distance to Paris $\times 1600$ & & & & & & $\begin{array}{c}11.918 \\
(39.758)\end{array}$ & $\begin{array}{c}-74.258 \\
(56.2)\end{array}$ \\
\hline Log distance to Paris $\mathrm{x} 1700$ & & & & & & $\begin{array}{c}253.596 * * * \\
(92.992)\end{array}$ & $\begin{array}{l}191.423 * \\
(115.862)\end{array}$ \\
\hline Log distance to Paris $\mathrm{x} 1800$ & & & & & & $\begin{array}{c}95.866 * * \\
(37.056)\end{array}$ & $\begin{array}{c}48.07 \\
(45.256)\end{array}$ \\
\hline Log distance to Paris $\mathrm{x} 1860$ & & & & & & $\begin{array}{c}32.496 \\
(35.486)\end{array}$ & $\begin{array}{l}-24.559 \\
(42.461)\end{array}$ \\
\hline Log distance to Paris $\mathrm{x} 1930$ & & & & & & $\begin{array}{c}1.018 \\
(51.557)\end{array}$ & $\begin{array}{l}-43.337 \\
(56.476)\end{array}$ \\
\hline Log distance to Paris $\mathrm{x} 1971$ & & & & & & $\begin{array}{c}13.333 \\
(58.984)\end{array}$ & $\begin{array}{l}-30.611 \\
(60.369)\end{array}$ \\
\hline Log distance to Paris $\mathrm{x} 2005$ & & & & & & $\begin{array}{c}9.594 \\
(56.436)\end{array}$ & $\begin{array}{l}-36.495 \\
(57.987)\end{array}$ \\
\hline Time dummies & Yes & Yes & Yes & Yes & Yes & Yes & Yes \\
\hline Province dummies & Yes & Yes & Yes & Yes & Yes & Yes & Yes \\
\hline$R^{2}$ & 0.38 & 0.38 & 0.38 & 0.39 & 0.4 & 0.39 & 0.42 \\
\hline Number of observations & 538 & 538 & 538 & 538 & 538 & 538 & 538 \\
\hline
\end{tabular}

Notes: Panel specifications that regress each province's level of development relative to the national average over the 1000-2005 period on the interaction between rate of Reconquest and time dummies, with data measured at the beginning of each century up to 1800 , and then at 1860, 1930,1970 and 2005. For the periods prior to 1860 for which there are no available data on GDP per capita, we employ density of urban population. Variables descriptions are provided in Table 9. The estimations include a constant term, which is omitted for space considerations. Robust standard errors are in parentheses. Small-sample correction for standard errors is applied. *, ** and *** denote significance at the 10,5 and $1 \%$ level, respectively. 


\begin{tabular}{|c|c|c|c|c|c|c|c|c|}
\hline The channel variable $\rightarrow$ & $\begin{array}{c}\text { Percentage of } \\
\text { landless } \\
\text { workers } 1797\end{array}$ & $\begin{array}{c}\text { Percentage of } \\
\text { landless } \\
\text { workers } 1956\end{array}$ & $\begin{array}{c}\text { Percentage of } \\
\text { population entities } \\
\text { under seigneurial } \\
\text { jurisdiction in } 1787\end{array}$ & Family types & $\begin{array}{l}\text { Moorish } \\
\text { ancestry }\end{array}$ & $\begin{array}{c}\text { Market } \\
\text { fragmentation } \\
\text { (Road density in } \\
1760)\end{array}$ & $\begin{array}{c}\text { Percentage of } \\
\text { population entities } \\
\text { under Church } \\
\text { jurisdiction in } 1787\end{array}$ & $\begin{array}{c}\text { Religiosity } \\
\text { (Clerical } \\
\text { population in } \\
\text { 1797) }\end{array}$ \\
\hline & (1) & (2) & (3) & (4) & (5) & (6) & (7) & (8) \\
\hline
\end{tabular}

Panel A: Second stage (Log GDP pc 2005 regressed on the predicted values of the channel variable)

\begin{tabular}{|c|c|c|c|c|c|c|c|c|}
\hline The channel variable & $\begin{array}{c}-0.009 * * * \\
(0.003)\end{array}$ & $\begin{array}{c}-0.008^{* * *} \\
(0.002)\end{array}$ & $\begin{array}{c}-0.010^{* *} \\
(0.004)\end{array}$ & $\begin{array}{c}25.689 \\
(44.709)\end{array}$ & $\begin{array}{c}0.014 \\
(0.011)\end{array}$ & $\begin{array}{c}-78.654 \\
(158.623)\end{array}$ & $\begin{array}{c}0.034^{* *} \\
(0.015)\end{array}$ & $\begin{array}{l}-85.605 \\
(64.005)\end{array}$ \\
\hline Geo-climatic controls & Yes & Yes & Yes & Yes & Yes & Yes & Yes & Yes \\
\hline Standardized beta & $-0,770$ & $-0,694$ & $-0,750$ & 8,385 & 0,506 & $-4,057$ & 1,687 & $-1,536$ \\
\hline
\end{tabular}

Panel B: First stage (The channel variable regressed on rate of Reconquest)

\begin{tabular}{|c|c|c|c|c|c|c|c|c|}
\hline Rate of Reconquest & $\begin{array}{c}1.683^{* * * *} \\
(0.402)\end{array}$ & $\begin{array}{c}1.915 * * * \\
(0.473)\end{array}$ & $\begin{array}{l}1.58^{* *} \\
(0.696)\end{array}$ & $\begin{array}{l}-0.001 \\
(0.001)\end{array}$ & $\begin{array}{l}-0.456 \\
(0.277)\end{array}$ & $\begin{array}{c}0,000 \\
(0.000)\end{array}$ & $\begin{array}{c}-0.461 * * \\
(0.181)\end{array}$ & $\begin{array}{c}0,000 \\
(0.000)\end{array}$ \\
\hline F-Statistic & 17,53 & 16,41 & 5,15 & 0,37 & 2,71 & 0,24 & 6,47 & 1,67 \\
\hline Partial $R^{2}$ & 0,327 & 0,355 & 0,116 & 0,006 & 0,077 & 0,006 & 0,074 & 0,077 \\
\hline Geo-climatic controls & Yes & Yes & Yes & Yes & Yes & Yes & Yes & Yes \\
\hline Standardized beta & 0,514 & 0,567 & 0,393 & $-0,084$ & $-0,334$ & 0,000 & $-0,231$ & 0,000 \\
\hline$R^{2}$ & 0,70 & 0,68 & 0,36 & 0,78 & 0,60 & 0,47 & 0,64 & 0,61 \\
\hline Number of observations & 45 & 45 & 45 & 45 & 43 & 45 & 45 & 45 \\
\hline \multicolumn{9}{|c|}{ Panel C: OLS regressions of Log GDP pc 2005 on the channel variable } \\
\hline The channel variable & $\begin{array}{c}-0.004 * * \\
(0.002)\end{array}$ & $\begin{array}{c}-0.006^{* * *} \\
(0.001)\end{array}$ & $\begin{array}{c}-0.003 * * * \\
(0.001)\end{array}$ & $\begin{array}{l}-0.178 \\
(0.565)\end{array}$ & $\begin{array}{l}0.005^{*} \\
(0.003)\end{array}$ & $\begin{array}{l}-1.814 \\
(2.162)\end{array}$ & $\begin{array}{c}0.003 \\
(0.002)\end{array}$ & $\begin{array}{l}-9.355 \\
(7.905)\end{array}$ \\
\hline Geo-climatic controls & Yes & Yes & Yes & Yes & Yes & Yes & Yes & Yes \\
\hline Standardized beta & $-0,408$ & $-0,631$ & $-0,375$ & $-0,066$ & 0,213 & $-0,137$ & 0,186 & $-0,215$ \\
\hline$R^{2}$ & 0,72 & 0,80 & 0,74 & 0,63 & 0,82 & 0,64 & 0,65 & 0,65 \\
\hline Number of observations & 45 & 45 & 45 & 45 & 43 & 45 & 45 & 45 \\
\hline
\end{tabular}

Notes : Variables descriptions are provided in Table 9. All the estimations include the control set employed in the baseline specification (column 1, Table 2) and a constant term, which are omitted for space considerations. Robust standard errors are in parentheses. Small-sample correction for standard errors is applied in 2SLS regressions. *, ** and *** denote significance at the 10,5 and $1 \%$ level, respectively. The respective standardized beta coefficients are reported in the bottom part of each panel.

TABLE 8 - OUTCOMES INDICATORS IN THE 1860s

\begin{tabular}{|c|c|c|c|c|c|c|c|c|}
\hline $\begin{array}{c}\text { The outcome indicator in } \\
\text { the } 1860 \mathrm{~s} \rightarrow\end{array}$ & $\begin{array}{c}\text { Literacy } \\
\text { rate }\end{array}$ & $\begin{array}{l}\text { School } \\
\text { enrollment }\end{array}$ & $\begin{array}{l}\text { Infant } \\
\text { mortality }\end{array}$ & $\begin{array}{c}\text { Life } \\
\text { expectancy }\end{array}$ & $\begin{array}{l}\text { Percentage of } \\
\quad \text { electors }\end{array}$ & $\begin{array}{l}\text { Percentage of } \\
\text { voters }\end{array}$ & Crimes & Convicts \\
\hline & (1) & (2) & (3) & (4) & (5) & (6) & (7) & (8) \\
\hline
\end{tabular}

Panel A: 2SLS results (The outcome indicator regressed on the predicted value of the percentage of landless workers in 1797)

$\begin{array}{lccccccccc}\text { Percentage of landless } & -0.32 * * & -0.002 * & 0.64 & -0.15 * * & -0.001 * * * & -0.001 * & 0.037 * * & 0.03 * * * \\ \text { workers 1797 } & (0.141) & (0.001) & (0.64) & (0.064) & (0.00) & (0.00) & (0.013) & (0.01) \\ \text { Geo-climatic controls } & \text { Yes } & \text { Yes } & \text { Yes } & \text { Yes } & \text { Yes } & \text { Yes } & \text { Yes } & \text { Yes } \\ \text { Standardized beta } & -0,515 & -0,398 & 0,229 & -0,488 & -0,549 & -0,764 & 0,656 & 0,712\end{array}$

Panel B: Reduced-form effect (The outcome indicator regressed on rate of Reconquest)

\begin{tabular}{lcccccccc} 
Rate of Reconquest & $-0.539 * * *$ & $-0.003 * *$ & 1.078 & $-0.253 * *$ & $-0.002 * * *$ & $-0.001 *$ & $0.062 * * *$ & $0.05 * * *$ \\
& $(0.182)$ & $(0.001)$ & $(1.074)$ & $(0.111)$ & $(0.00)$ & $(0.00)$ & $(0.022)$ & $(0.013)$ \\
Geo-climatic controls & Yes & Yes & Yes & Yes & Yes & Yes & Yes & Yes \\
Standardized beta & $-0,316$ & $-0,218$ & 0,140 & $-0,299$ & $-0,400$ & $-0,278$ & 0,400 & 0,432 \\
$R^{2}$ & 0,77 & 0,74 & 0,58 & 0,66 & 0,64 & 0,51 & 0,57 & 0,63 \\
Number of observations & 45 & 45 & 45 & 45 & 45 & 45 & 45 \\
\hline
\end{tabular}

Notes: Variables descriptions are provided in Table 9. All the estimations include the control set employed in the baseline specification (column 1, Table 2) and a constant term, which are omitted for space considerations. Robust standard errors are in parentheses. Small-sample correction for standard errors is applied in 2SLS regressions. *,** and *** denote significance at the 10,5 and $1 \%$ level, respectively. The respective standardized beta coefficients are reported in the bottom part of each panel. 


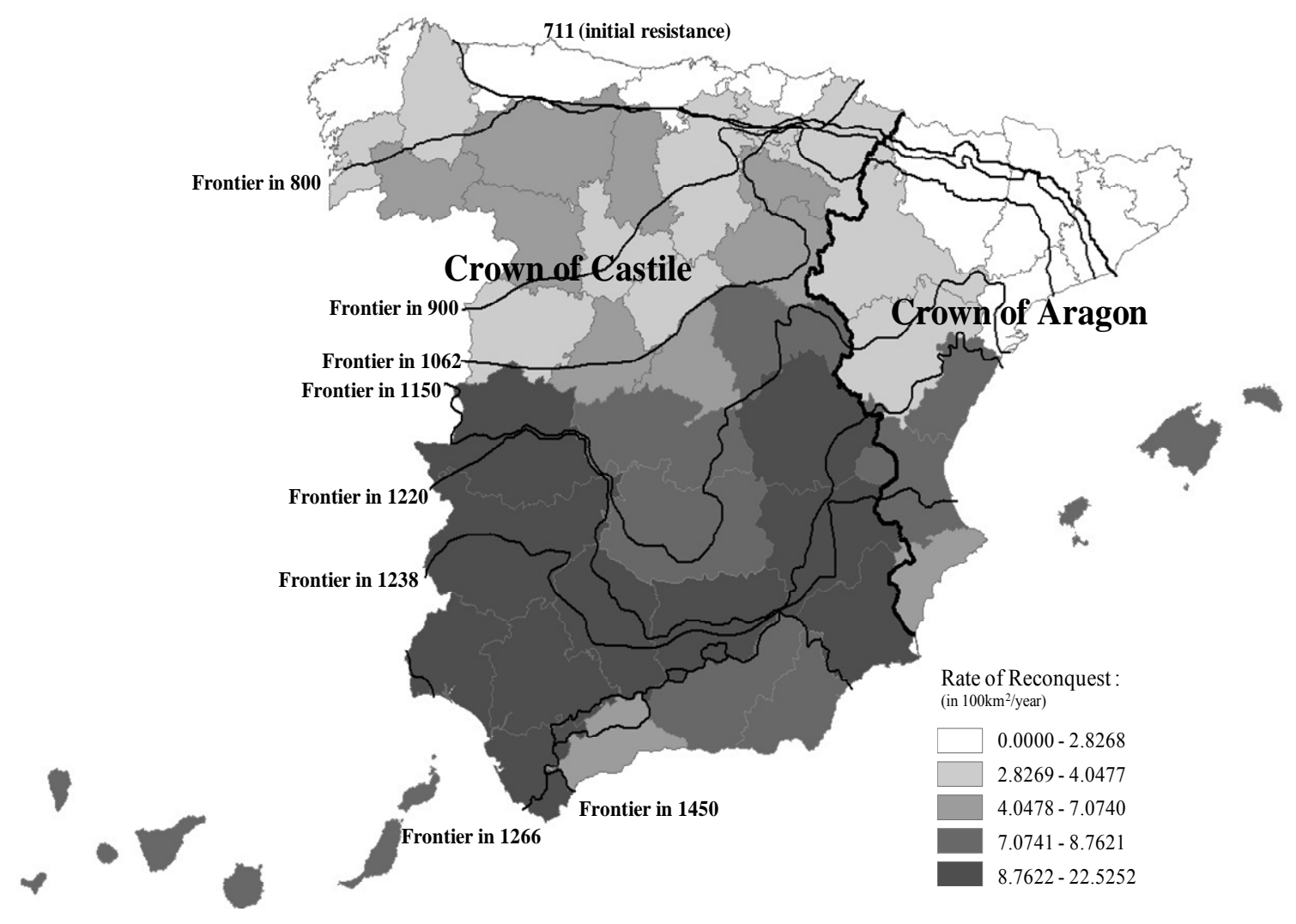

Figure 1. The Spanish Reconquest (711-1492)

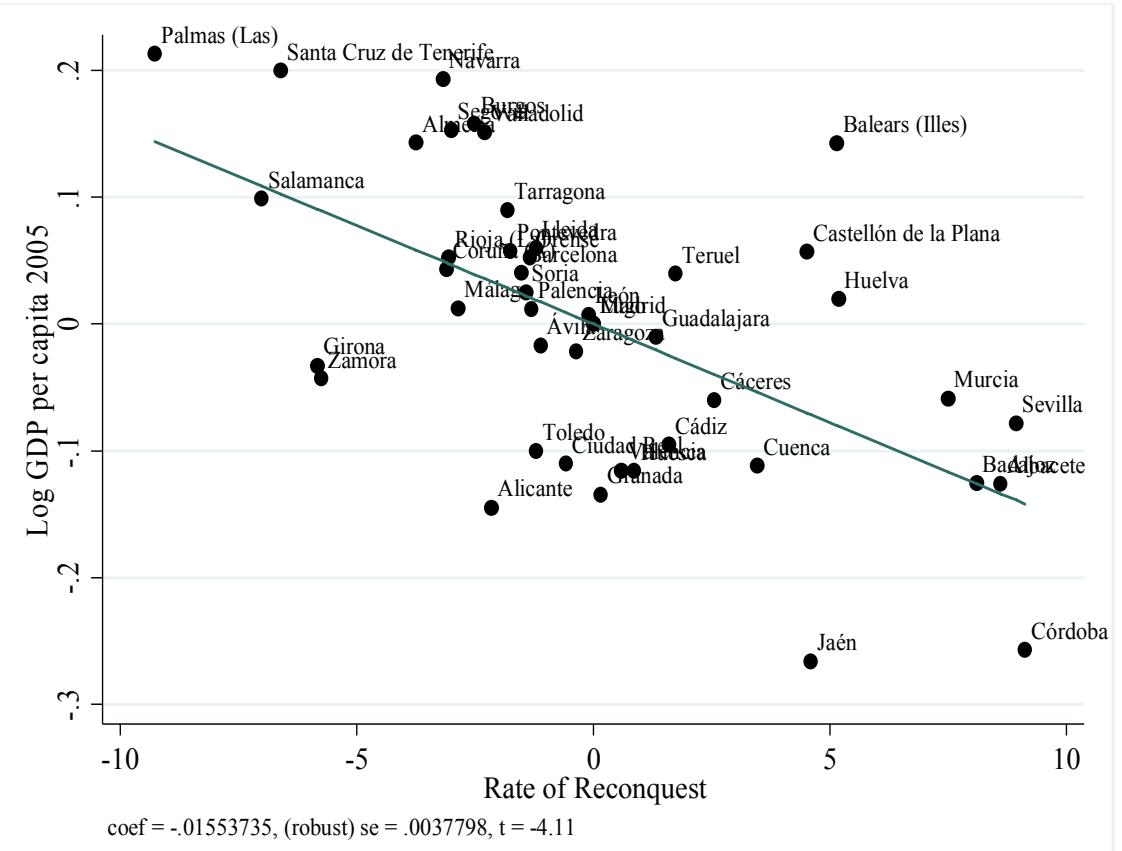

Figure 2. Conditional relationship between current GDP per capita and rate of Reconquest 


\section{Appendix}

See Table 9.

TABLE 9 - DESCRIPTION OF VARIABLES (I)

\begin{tabular}{lll}
\hline Variable & Description & Source \\
\hline Main dependent variable &
\end{tabular}

Main dependent variable

Log GDP per capita in 2005 Natural logarithm of GDP per capita in 2005.

Spanish Regional Accounts. Base 2000 (Spanish National Statistics Institute, INE).

\section{Reconquest indicators}

Rate of Reconquest

Rate of Reconquest corresponding to the provincial centroid

Stages of Reconquest with homogeneous time interval This indicator is calculated as follows: (i) Provinces are classified according to divided into stages of the same duration. The five Cantabrian provinces not occupied by the Muslims are considered separately, with a value equal to 0 . (ii) For each century, we compute the total land area reconquered in that period, differentiating between the areas conquered by Castile and Aragon. (iii) Then, the rate of Reconquest in a given province is the total land area that was reconquered in the century in which that province was reconquered, expressed in $100 \mathrm{~km}^{2} /$ year.

Post-1212 conquest

Dummy variable indicating whether the province was reconquered after the collapse of the Almohad Empire in 1212 in the battle of Las Navas de Tolosa.

Agricultural land in 1900

Percentage of agricultural area over provincial surface area in 1900

Percentage of arable land over total surface area in 1962.

Average altitude of the province (simple average of the municipalities of the province)

Authors' elaboration using information from Mestre-Campi and Sabaté (1998) and Guichard (2002), among others.

Barciela et al. (2005).

1962 agricultural census (INE) (www.ine.es).

Authors' elaboration using information from Mestre-Campi and Sabaté (1998).

Authors' elaboration using information from Mestre-Campi and Sabaté (1998).

Authors' elaboration using information from Mestre-Campi and Sabaté (1998)

Geographic Nomenclature of Municipalities and Local Population (Instituto Geográfico Nacional -IGN- 2012). 


Variable
Controls (continued)

Average urban population density at conquest in the Christian kingdom

Border with Portugal

Centuries under Muslim domination

Coal dummy in 1860

Coal output in 1860

Coast dummy

Coast length/ surface area

Crown of Aragon

Distance from London, Paris Natural logarithm of the linear distance between the centroid of the province and and Mainz

Distance from Madrid

Distance to the coast

Humidity, Temperature and Rainfall

Island

Latitude

Land suitability for cotton

Land suitability for sugar

Land suitability for tobacco

Madrid

Mediterranean Sea, Atlantic Ocean, Cantabrian Sea

Roman roads density

Ruggedness

Coefficient of variation of the altitude of the municipalities of the province.
Average density of urban population (inhabitants in cities greater than or equal to 5000 inhabitants over provincial surface area in $\mathrm{km}^{2}$ ) in Castile or Aragon just before the conquest of the province.

Dummy variable indicating whether the province is in the border with Portugal.

Number of centuries that the province was under Muslim domination. It is calculated as the closest integer to the difference between the year of the Reconquest of the capital city of the province and the date of the Muslim invasion (711).

Dummy variable indicating whether the province had some coal mine in 1860 .

Logarithm of the value created by coal mining in 1860 .

Dummy variable indicating whether the province has coast.

Length of coast over surface area.

Dummy variable capturing whether the province belonged to the Crown of Aragon. London, Paris or Mainz (in $100 \mathrm{~km}$ ), using ArcGIS.

Natural logarithm of the linear distance between the centroid of the province and Madrid (in $100 \mathrm{~km}$ ), using ArcGIS.

Linear distance between the centroid of the province and the nearest point of the coast (in $100 \mathrm{~km}$ ), using ArcGIS. For the three provinces that are islands, this variable takes the value of 0 .

Annual average temperature, rainfall and relative humidity.

Dummy variable indicating whether the province is an island.

Latitude of the centroid of the province, using ArcGIS.

Provincial average of the crop suitability index for low input level rain-fed cotton.

Provincial average of the crop suitability index for low input level rain-fed sugarcane.

Provincial average of the crop suitability index for low input level rain-fed tobacco.

Dummy variable indicating the capital city of Spain.

Dummy variables indicating whether the province has access to the Mediterranean Sea, the Atlantic Ocean or the Cantabrian Sea.

Length of Roman roads (in meters) over provincial surface area (in $\mathrm{km}^{2}$ ).

Source

Authors' elaboration using information from Bairoch (1988).

Authors' elaboration.

Authors' elaboration using information from Mestre-Campi and Sabaté (1998) and Guichard (2002), among others.

1860-1861 Statistical Yearbook of Spain (Junta General de Estadística -JGE- 1863a).

1860-1861 Statistical Yearbook of Spain (JGE 1863a).

Authors' elaboration.

Physical variables. Territory (INE) (www.ine.es).

Authors' elaboration.

Authors' elaboration.

Authors' elaboration.

Authors' elaboration.

Standard Climate Values (Agencia Estatal de Meteorología 2012).

Authors' elaboration.

Authors' elaboration

Authors' elaboration using data from FAO/IIASA (2010).

Authors' elaboration using data from FAO/IIASA (2010).

Authors' elaboration using data from FAO/IIASA (2010).

Authors' elaboration.

Authors' elaboration.

Authors' elaboration using

ArcGIS and data from García de Cortázar (2007).

Geographic Nomenclature of Municipalities and Local Population (Instituto Geográfico Nacional -IGN- 2012). 


\begin{tabular}{|c|c|}
\hline Variable & Description \\
\hline \multicolumn{2}{|l|}{ Controls (continued) } \\
\hline Soil quality & $\begin{array}{l}\text { Average of seven key soil dimensions important for crop production: nutrient } \\
\text { availability, nutrient retention capacity, rooting conditions, oxygen availability to } \\
\text { roots, excess salts, toxicities, and workability. For each component, we calculate } \\
\text { the provincial average value. }\end{array}$ \\
\hline $\begin{array}{l}\text { Urban population density in } \\
800\end{array}$ & $\begin{array}{l}\text { Density of urban population (inhabitants in cities greater than or equal to } 5000 \\
\text { inhabitants over provincial surface area in } \mathrm{km}^{2} \text { ) in } 800 \text {. }\end{array}$ \\
\hline $\begin{array}{l}\text { Urban population density at } \\
\text { conquest }\end{array}$ & $\begin{array}{l}\text { Density of urban population (inhabitants in cities greater than or equal to } 5000 \\
\text { inhabitants over provincial surface area in } \mathrm{km}^{2} \text { ) in the latest available date } \\
\text { previous to the conquest of the province by the Christians. }\end{array}$ \\
\hline Wooded steppe (\% area) & Percentage of province area that was subject to wooded steppe 10,000 years ago. \\
\hline $\begin{array}{l}\text { Years since transition to } \\
\text { agriculture }\end{array}$ & $\begin{array}{l}\text { This variable is constructed for each province using the following equation: } \\
\mathrm{Y}\left(S_{0}\right)=\Sigma \lambda_{\mathrm{i}} \mathrm{Y}\left(S_{i}\right) \text {, where } \mathrm{Y}\left(S_{0}\right) \text { is the predicted date of adoption of agriculture } \\
\left.\text { for the centroid of each respective province (denoted by } S_{0}\right) \text {. } \Sigma \text { means a sum } \\
\text { from site } 1 \text { to } \mathrm{N} \text {, where } \mathrm{N} \text { is the number of measured sample points surrounding } \\
S_{0} \text {. We restrict the measured sample points to those located in the Iberian } \\
\text { Peninsula that make a total of } 13 \text { Neolithic sites. } \mathrm{Y}\left(S_{i}\right) \text { is the observed value of } \\
\text { the predicted date of early adoption of agriculture in Neolithic site } S_{i} . \lambda_{\mathrm{i}} \text { are } \\
\text { weights calculated as } \lambda_{\mathrm{i}}=\left(\mathrm{D} / d_{i}\right) / \Sigma\left(\mathrm{D} / d_{i}\right) \text {, where } \Sigma \lambda_{\mathrm{i}}=1 \text { and } d_{i} \text { is the distance } \\
\text { between } S_{0} \text { and each Neolithic site } S_{i} \text {. } \mathrm{D}=\Sigma d_{i} \text { is the total sum of the } 13 d_{i} \text { for } \\
\text { the centroid of each respective province }\left(S_{0}\right) \text {. Note that }\left(\mathrm{D} / d_{i}\right) \text { implies that we } \\
\text { assign greater weights to those sites located closer to the centroid of each } \\
\text { province. }\end{array}$ \\
\hline
\end{tabular}

Source

Authors' elaboration using data from Fischer et al. (2008).

Bairoch (1988).

Authors' elaboration using information from Bairoch (1988).

Authors' elaboration using ArcGIS and information from Olsson and Paik (2013).

Authors' elaboration using ArcGIS and data from Pinhasi, Fort and Ammerman (2005).

Variables of pre-Reconquest development (not described above)

Ancient settlements over surface area

City population in 800

Coinage of imperial Roman coins over surface area

Number of bishoprics circa 600 over surface area

Roman roads density: Main roads

Roman villas over surface area 800 . Length
$\mathrm{km}^{2}$ ).

Number of ancient (pre-medieval) settlements over provincial surface area (in $1,000 \mathrm{~km}^{2}$ ).

Inhabitants (in thousands) in cities greater than or equal to 5000 inhabitants in

Number of points of coinage of imperial Roman coins over provincial surface area (in $1,000 \mathrm{~km}^{2}$ ).

Number of bishoprics circa 600 over provincial surface area (in 1,000 $\mathrm{km}^{2}$ ).

Length of the main Roman roads (in meters) over provincial surface area (in

Number of Roman villas over provincial surface area (in $1,000 \mathrm{~km}^{2}$ ).
Authors' elaboration using ArcGIS and data from Pleiades (2014).

Bairoch (1988).

Authors' elaboration using data from García de Cortázar (2007).

Authors' elaboration using data from Digital Atlas of Roman and Medieval Civilizations v. 1.1 .

Authors' elaboration using ArcGIS and data from García de Cortázar (2007).

Authors' elaboration using ArcGIS and data from Pleiades (2014). 


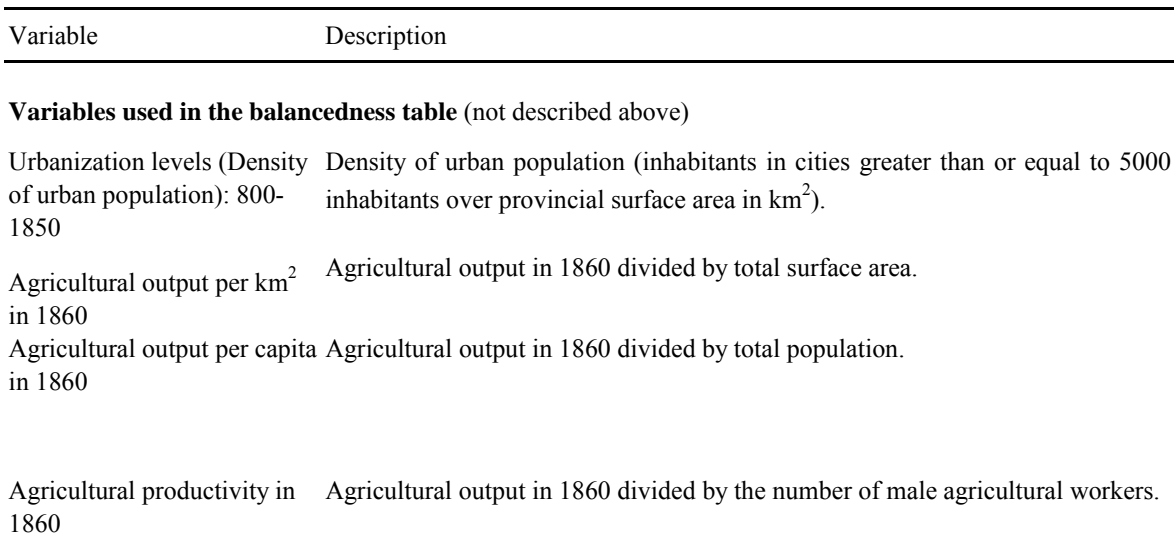

Agricultural share over GDP Agricultural output in 1860 divided by total provincial output. $(\%)$ in 1860

Productive land (\%) in 1900 Percentage of productive land over provincial surface area in 1900.

Wheat output per hectare in Volume of wheat output (in Spanish bushels) per hectare in 1916. 1916

Agricultural output per ha in Agricultural output (average 1949-1951) (in pesetas) over provincial surface area 1950

Variables Used in Section VI on the Timing of the Effects (not described above)

Relative GDP per capita in Relative GDP per capita with respect to the Spanish average, in 1860, 1930, 1860, 1930, 1971 and 2005. 1971, and 2005.

Relative industrial output per capita in 1860, 1930, 1970 and 2005.

Total UK industrial output

Total US industrial output

\section{Variables used as mechanisms}

Family types

Moorish ancestry

Religiosity (Clerical population in 1797)

Land concentration in 1962

Land Gini Index in 1972

Percentage of landless workers in 1797

Percentage of landless workers in 1956 (in ha).
Relative industrial output per capita with respect to the Spanish average, in 1860, 1930, 1971, and 2005.

Total industrial output of the United Kingdom in 1860, 1930, 1971 and 2005. Base year is 1913

Total industrial output of the United States in 1860, 1930, 1971 and 2005. Base year is 1899 .
Source

Bairoch (1988).

Authors' elaboration from Rosés et al. (2010).

Authors' elaboration from Rosés et al. (2010) and the 1860 population census (JGE 1863b).

Authors' elaboration from Rosés et al. (2010), Erdozáin and Mikelarena (1999), and the 1860 population census (JGE 1863b).

Rosés et al. (2010).

Barciela et al. (2005).

1916 Statistical Yearbook of Spain (INE).

García Barbancho (1954).

Rosés et al (2010) for 1860 and 1930; Carreras et al. (2005) for 1971; and Spanish Regional Accounts. Base 2000 (INE) for 2005.

Rosés et al. (2010) for 1860; Carreras (2005) for 1930 and 1970; Spanish Regional Accounts. Base 2000 (INE) for 2005

Mitchell (2007a) and IMF (2013)

Mitchell (2007b) and IMF (2013)

1860 population census (JGE 1863b).

Adams et al. (2008).

Authors' elaboration using data from Morales (1998) and 1797 population census (INE, 1992). in 1797 . We impute data from historical regions to current provinces by estimating (with ArcGIS) the percentage of area in each province that corresponds to each historical region.

1962 agricultural census (INE). 1962.

Gini Index of private land considering the legal status of the farmer, measured in 1972.

Percentage of landless workers over the agricultural active population in 1797 We impute data from historical regions to current provinces by estimating (with ArcGIS) the percentage of area in each province that corresponds to each historical region.

Percentage of landless workers over the agricultural active population in 1956.

\section{Ruiz-Maya (1979)}

Authors' elaboration using data from Morales (1998) and 1797 population census (INE, 1992).

Junta Nacional de Hermandades (1959). 


\begin{tabular}{lll}
\hline Variable & Description & Source \\
\hline
\end{tabular}

\section{Variables used as mechanisms (Continued)}

Percentage of population entities under Church jurisdiction in 1787

Percentage of population entities under seigneurial jurisdiction in 1787

Variable measuring the percentage of population entities under ecclesiastical jurisdiction in 1787 .

Variable measuring the percentage of population entities under either noble or military order jurisdiction in 1787 .

Market fragmentation (Road Kilometers of roads in 1760 ("caminos de ruedas") over provincial surface area density in 1760) (in $\mathrm{km}^{2}$ ).
Authors' elaboration using the 1787 population census (INE, 1987).

Authors' elaboration using the 1787 population census (INE, 1987).

Authors' elaboration using ArcGIS and data from IGN (2008).

\section{Outcomes variables in the $1860 \mathrm{~s}$}

Convicts and Crimes

Infant mortality

Life expectancy

Literacy rate

Percentage of electors and voters

School enrollment
Total crimes committed over total population in 1860 (in thousands). Total convicts over total population in 1860 (in thousands).

Infant mortality rates. Probability of dying (per thousand) of individuals under one year in 1860 .

Life expectancy at birth in 1860 .

Total literacy rates for the adult population in 1860 .

Electors (or voters) in the parliamentary election of 1865 as a percentage of the male population aged 25 or older.

Total children enrolled over the population under 15 years.
1860-1861 Statistical Yearbook of Spain (JGE 1863a); 1860 population census (JGE 1863b).

Regional and provincial mortality tables. Spain 1860 (ProyectoNisal, 2014).

Regional and provincial mortality tables. Spain 1860 (ProyectoNisal, 2014).

Núñez (1992).

Authors' elaboration from the 1862-1865 Statistical Yearbook of Spain (JGE 1865) and the 1860 population census (JGE 1863b).

Authors' elaboration from the 1860 population census (JGE 1863b).

\section{Variables at municipal level}

Altitude

Altitude corresponding to the municipality centroid.

Annual average temperature Annual average temperature corresponding to the municipality centroid (in centigrade degrees multiplied by 10 ).

Annual rainfall

Annual precipitation corresponding to the municipality centroid (in millimeters).

Average number of vehicles per household

Number of vehicles (cars and vans) for personal transport owned by households, divided by the number of households. The year of measurement is 2001 .

Average socioeconomic condition

Average of class marks of socioeconomic conditions of individuals (multiplied by 100 ). Socioeconomic condition is obtained by combining information from the variables occupation, activity and professional situation. To illustrate the construction of this variable, a (maximum) class mark of 3 is given to nonagricultural entrepreneurs with employees, and a (minimun) class mark of 0 to those unemployed who have not worked previously. The year of measurement is 2001.
Geographic Nomenclature of Municipalities and Local Population (IGN 2012).

Authors' elaboration using ArcGIS and data from WorldClim (Hijmans et al., 2005).

Authors' elaboration using ArcGIS and data from WorldClim (Hijmans et al., 2005).

INE. Censos de Población y Viviendas 2001 (www.ine.es).

INE. Censos de Población y Viviendas 2001 (www.ine.es). 


\begin{tabular}{|c|c|c|}
\hline Variable & Description & Source \\
\hline \multicolumn{3}{|c|}{ Variables at municipal level (Continued) } \\
\hline Distance to Madrid & $\begin{array}{l}\text { Linear distance between the centroid of the municipality and Madrid (in } \mathrm{km} \text { ), } \\
\text { using ArcGIS. }\end{array}$ & Authors' elaboration. \\
\hline Distance to the coast & $\begin{array}{l}\text { Linear distance between the centroid of the municipality and the nearest point of } \\
\text { the coast (in } \mathrm{km} \text { ), using ArcGIS. }\end{array}$ & Authors' elaboration. \\
\hline $\begin{array}{l}\text { Distance to the nearest } \\
\text { capital }\end{array}$ & $\begin{array}{l}\text { Linear distance between the centroid of the municipality and the nearest } \\
\text { provincial capital (in } \mathrm{km} \text { ), using ArcGIS. }\end{array}$ & Authors' elaboration. \\
\hline Excess salts & $\begin{array}{l}\text { This variable assesses the following soil characteristics: "Soil salinity, soil } \\
\text { sodicity and soil phases influencing salt conditions". We calculate the average } \\
\text { value of the municipality. }\end{array}$ & $\begin{array}{l}\text { Authors' elaboration using } \\
\text { ArcGIS and data from Fischer et } \\
\text { al. (2008). }\end{array}$ \\
\hline $\begin{array}{l}\text { High rate of Reconquest }(> \\
\text { provincial average) or }(> \\
\left.1.25^{*} \text { provincial average }\right)\end{array}$ & $\begin{array}{l}\text { Dummy variable indicating whether the rate of Reconquest corresponding to the } \\
\text { municipality is higher than the provincial average, or } 1.25 \text { times higher than the } \\
\text { provincial average. }\end{array}$ & $\begin{array}{l}\text { Authors' elaboration using } \\
\text { ArcGIS and information from } \\
\text { Mestre-Campi and Sabaté (1998). }\end{array}$ \\
\hline Labor force activity rate & $\begin{array}{l}\text { Labor force activity rate of the population between } 20 \text { and } 59 \text { years old. The year } \\
\text { of measurement is } 2001 .\end{array}$ & $\begin{array}{l}\text { INE. Censos de Población y } \\
\text { Viviendas } 2001 \text { (www.ine.es). }\end{array}$ \\
\hline Latitude & Latitude of the municipality centroid. & $\begin{array}{l}\text { Geographic Nomenclature of } \\
\text { Municipalities and Local } \\
\text { Population (IGN 2012). }\end{array}$ \\
\hline Nutrient availability & $\begin{array}{l}\text { This variable assesses the following soil characteristics: "Soil texture, soil } \\
\text { organic carbon, soil } p H \text {, total exchangeable bases". We calculate the average } \\
\text { value of the municipality. }\end{array}$ & $\begin{array}{l}\text { Authors' elaboration using } \\
\text { ArcGIS and data from Fischer et } \\
\text { al. (2008). }\end{array}$ \\
\hline Nutrient retention capacity & $\begin{array}{l}\text { This variable assesses the following soil characteristics: "Soil organic carbon, } \\
\text { soil texture, base saturation, cation exchange capacity of soil and of clay } \\
\text { fraction". We calculate the average value of the municipality. }\end{array}$ & $\begin{array}{l}\text { Authors' elaboration using } \\
\text { ArcGIS and data from Fischer et } \\
\text { al. (2008). }\end{array}$ \\
\hline Oxygen availability to roots & $\begin{array}{l}\text { This variable assesses the following soil characteristics: "Soil drainage and soil } \\
\text { phases affecting soil drainage". We calculate the average value of the } \\
\text { municipality. }\end{array}$ & $\begin{array}{l}\text { Authors' elaboration using } \\
\text { ArcGIS and data from Fischer et } \\
\text { al. (2008). }\end{array}$ \\
\hline Population & Log of total population in 2001. & $\begin{array}{l}\text { INE. Censos de Población y } \\
\text { Viviendas } 2001 \text { (www.ine.es). }\end{array}$ \\
\hline Provincial capital dummy & Dummy variable indicating whether the municipality is a provincial capital city. & Authors' elaboration. \\
\hline Rate of Reconquest & $\begin{array}{l}\text { This variable is created in a similar way to the provincial level variable. In this } \\
\text { case, we assign to each municipality the reconquered area corresponding to the } \\
\text { stage of the Reconquest to which the municipality centroid belongs. }\end{array}$ & $\begin{array}{l}\text { Authors' elaboration using } \\
\text { ArcGIS and information from } \\
\text { Mestre-Campi and Sabaté (1998). }\end{array}$ \\
\hline Rooting conditions & $\begin{array}{l}\text { This variable assesses the following soil characteristics: "Soil textures, bulk } \\
\text { density, coarse fragments, vertic soil properties and soil phases affecting root } \\
\text { penetration and soil depth and soil volume". We calculate the average value of } \\
\text { the municipality. }\end{array}$ & $\begin{array}{l}\text { Authors' elaboration using } \\
\text { ArcGIS and data from Fischer et } \\
\text { al. (2008). }\end{array}$ \\
\hline Toxicity & $\begin{array}{l}\text { This variable assesses the following soil characteristics: "Calcium carbonate } \\
\text { and gypsum". We calculate the average value of the municipality. }\end{array}$ & $\begin{array}{l}\text { Authors' elaboration using } \\
\text { ArcGIS and data from Fischer et } \\
\text { al. (2008). }\end{array}$ \\
\hline Workability & $\begin{array}{l}\text { This variable assesses the following soil characteristics: "Soil texture, effective } \\
\text { soil depth/volume, and soil phases constraining soil management (soil depth, } \\
\text { rock outcrop, stoniness, gravel/concretions and hardpans)". We calculate the } \\
\text { average value of the municipality. }\end{array}$ & $\begin{array}{l}\text { Authors' elaboration using } \\
\text { ArcGIS and data from Fischer et } \\
\text { al. (2008). }\end{array}$ \\
\hline
\end{tabular}




\title{
(NOT FOR PUBLICATION)
}

\section{Supplementary Appendices}

to

\section{“The Economic Consequences of the Spanish Reconquest: The Long-term Effects of Medieval Conquest and Colonization”}

\author{
Daniel Oto-Peralías \& Diego Romero-Ávila
}

April 2016

\section{This appendix includes:}

Appendix A The Reconquest and the pattern of settlement in Spain: The effect of rate of Reconquest on the average surface area of municipalities.

Appendix B Descriptive statistics.

Appendix C The effect of rate of Reconquest: Alternative functional forms.

Appendix D Replication of tables 1 and 2 using the full sample of 50 Spanish provinces.

Appendix E Replication of Table 2 using two alternative small-sample correction methods.

Appendix F Replication of Table 2 correcting standard errors (SEs) for spatial dependence.

Appendix G Tackling the North-South gradient issue.

Appendix H Exploiting variation across the stages of the Reconquest: Aggregating provincial-level data at the stage of Reconquest level.

Appendix I Exploiting variation across the stages of the Reconquest: Aggregating municipality-level data at the stage of Reconquest level.

Appendix J Municipality-level analysis correcting SEs for spatial dependence and clustering SEs at the province level.

Appendix K Correlations between indicators of pre-Reconquest development and suitability for agriculture.

Appendix L 2SLS regression using soil quality as an instrument.

Appendix M The timing of the effect of the Reconquest: Additional Regression results.

Appendix N Correlations between GDP per capita 2005 and several proxies for economic development over time.

Appendix O The timing of the effect of the Reconquest: Using industrialization in the UK and in the US as a proxy for the opportunity to industrialize.

Appendix P Implications of land inequality.

Appendix Q A case study of our theory applied to the development paths of Seville vs. Barcelona.

Appendix R Channel analysis with two alternative measures of land concentration, and on the persistence of land inequality over time.

Appendix S Current income distribution in the Spanish provinces. 


\section{Appendix A. The Reconquest and the pattern of settlement in Spain: The effect of rate of Reconquest on the average surface area of municipalities.}

TABLE A1 . THE EFFECT OF RATE OF RECONQUEST ON THE AVERAGE SIZE OF MUNICIPALITIES

\begin{tabular}{|c|c|c|c|c|c|c|}
\hline & \multicolumn{2}{|c|}{$\begin{array}{l}\text { Average size (in surface area) } \\
\text { of "singular population } \\
\text { entities" in } 1787\end{array}$} & \multicolumn{2}{|c|}{$\begin{array}{l}\text { Average size (in surface area) } \\
\text { of municipalities in } 2011\end{array}$} & \multicolumn{2}{|c|}{$\begin{array}{l}\text { Falsification test: } \\
\text { Average size of ancient (pre- } \\
\text { medieval) settlements }\end{array}$} \\
\hline & (1) & (2) & (3) & (4) & (5) & (6) \\
\hline Rate of Reconquest & $\begin{array}{l}5.06^{* * *} \\
(0.939)\end{array}$ & $\begin{array}{l}5.318^{* * *} \\
(1.205)\end{array}$ & $\begin{array}{c}6.164^{* * *} \\
(1.117)\end{array}$ & $\begin{array}{l}7.27^{* * *} \\
(1.372)\end{array}$ & $\begin{array}{c}0.042 \\
(0.028)\end{array}$ & $\begin{array}{l}-0.011 \\
(0.044)\end{array}$ \\
\hline Crown of Aragon & & $\begin{array}{c}24.636 \\
(19.065)\end{array}$ & & $\begin{array}{c}7.993 \\
(19.825)\end{array}$ & & $\begin{array}{l}-0.023 \\
(0.616)\end{array}$ \\
\hline Madrid & & $\begin{array}{l}-10.433 \\
(7.269)\end{array}$ & & $\begin{array}{l}-38.705^{* * *} \\
\quad(9.723)\end{array}$ & & $\begin{array}{c}-0.831 * * * \\
(0.301)\end{array}$ \\
\hline Rainfall & & $\begin{array}{c}0.032 \\
(0.046)\end{array}$ & & $\begin{array}{l}0.004 \\
(0.03)\end{array}$ & & $\begin{array}{c}0.001 \\
(0.001)\end{array}$ \\
\hline Soil quality & & $\begin{array}{l}-33.921 \\
(31.953)\end{array}$ & & $\begin{array}{l}-77.746 * * * \\
(28.276)\end{array}$ & & $\begin{array}{l}2.51^{* *} \\
(1.096)\end{array}$ \\
\hline Ruggedness & & $\begin{array}{l}-21.186 \\
(33.959)\end{array}$ & & $\begin{array}{c}-9.096 \\
(26.019)\end{array}$ & & $\begin{array}{c}1.203 \\
(0.762)\end{array}$ \\
\hline Mediterranean Sea & & $\begin{array}{c}-8.37 \\
(16.933)\end{array}$ & & $\begin{array}{l}-13.959 \\
(13.534)\end{array}$ & & $\begin{array}{c}-0.422 \\
(0.5)\end{array}$ \\
\hline Cantabrian Sea & & $\begin{array}{c}13.813 \\
(48.131)\end{array}$ & & $\begin{array}{l}36.214^{*} \\
(19.688)\end{array}$ & & $\begin{array}{l}-1.307 \\
(0.905)\end{array}$ \\
\hline Border with Portugal & & $\begin{array}{l}-12.836 \\
(11.55)\end{array}$ & & $\begin{array}{l}-42.041 * * * \\
(12.027)\end{array}$ & & $\begin{array}{l}-0.475 \\
(0.295)\end{array}$ \\
\hline Ln distance from Paris & & $\begin{array}{c}52.714 \\
(33.107)\end{array}$ & & $\begin{array}{c}43.531 \\
(35.009)\end{array}$ & & $\begin{array}{c}1.191 \\
(1.888)\end{array}$ \\
\hline Coal dummy in 1860 & & $\begin{array}{l}-7.455 \\
(9.718)\end{array}$ & & $\begin{array}{c}-4.187 \\
(11.597)\end{array}$ & & $\begin{array}{c}0.308 \\
(0.323)\end{array}$ \\
\hline$R^{2}$ & 0.61 & 0.68 & 0.49 & 0.66 & 0.05 & 0.32 \\
\hline Number of observations & 46 & 46 & 50 & 50 & 48 & 48 \\
\hline
\end{tabular}

Notes: The dependent variables are measured as the ratio of provincial surface area (in $\mathrm{km}^{2}$ ) to the number of population entities, municipalities or ancient settlements, respectively. Variables descriptions are provided in Table 9. The estimations include a constant term, which is omitted for space considerations. Robust standard errors are in parentheses. *, ** and *** denote significance at the 10,5 and $1 \%$ level, respectively. 
Appendix B. Descriptive statistics.

TABLE A2 - DESCRIPTIVE STATISTICS (I)

\begin{tabular}{|c|c|c|c|c|c|c|c|c|c|c|}
\hline \multirow[b]{2}{*}{ Variable } & \multicolumn{5}{|c|}{ Full sample } & \multicolumn{5}{|c|}{ Excluding the initial resistance area } \\
\hline & Obs & Mean & Std. Dev. & Min & Max & Obs & Mean & Std. Dev. & Min & Max \\
\hline \multicolumn{11}{|l|}{ Main dependent variable } \\
\hline Log GDP per capita in 2005 & 50 & 9.87 & 0.20 & 9.51 & 10.28 & 45 & 9.84 & 0.19 & 9.51 & 10.22 \\
\hline \multicolumn{11}{|l|}{ Reconquest indicators } \\
\hline Rate of Reconquest & 50 & 7.08 & 5.94 & 0.00 & 22.53 & 45 & 7.78 & 5.85 & 1.58 & 22.53 \\
\hline $\begin{array}{l}\text { Rate of Reconquest corresponding to } \\
\text { the provincial centroid }\end{array}$ & 50 & 7.30 & 6.90 & 0.00 & 22.66 & 45 & 8.11 & 6.81 & 0.58 & 22.66 \\
\hline $\begin{array}{l}\text { Stages of Reconquest with } \\
\text { homogeneous time interval }\end{array}$ & 50 & 5.73 & 4.86 & 0.00 & 14.66 & 45 & 6.37 & 4.71 & 0.59 & 14.66 \\
\hline Post- 1212 conquest & 50 & 0.36 & 0.48 & 0.00 & 1.00 & 45 & 0.40 & 0.50 & 0.00 & 1.00 \\
\hline \multicolumn{11}{|l|}{ Controls } \\
\hline Agricultural land in $1900(\%)$ & 48 & 0.33 & 0.15 & 0.06 & 0.71 & 43 & 0.36 & 0.14 & 0.10 & 0.71 \\
\hline Arable land in $1962(\%)$ & 50 & 0.40 & 0.17 & 0.04 & 0.80 & 45 & 0.43 & 0.15 & 0.17 & 0.80 \\
\hline Average altitude & 50 & 534.90 & 276.04 & 111.01 & $1,044.14$ & 45 & 565.25 & 270.40 & 121.19 & $1,044.14$ \\
\hline $\begin{array}{l}\text { Average urban population density at } \\
\text { conquest in the Christian kingdom }\end{array}$ & 50 & 0.48 & 0.46 & 0.00 & 1.54 & 45 & 0.53 & 0.46 & 0.00 & 1.54 \\
\hline Border with Portugal & 50 & 0.14 & 0.35 & 0.00 & 1.00 & 45 & 0.16 & 0.37 & 0.00 & 1.00 \\
\hline Centuries under Muslim domination & 50 & 3.64 & 2.38 & 0.00 & 8.00 & 45 & 4.04 & 2.15 & 0.00 & 8.00 \\
\hline Coal dummy in 1860 & 50 & 0.18 & 0.39 & 0.00 & 1.00 & 45 & 0.18 & 0.39 & 0.00 & 1.00 \\
\hline Coal output in 1860 & 50 & 1.90 & 4.18 & 0.00 & 14.84 & 45 & 1.78 & 3.91 & 0.00 & 12.29 \\
\hline Coast dummy & 50 & 0.44 & 0.50 & 0.00 & 1.00 & 45 & 0.40 & 0.50 & 0.00 & 1.00 \\
\hline Coast length/ surface area & 50 & 0.03 & 0.06 & 0.00 & 0.29 & 45 & 0.03 & 0.06 & 0.00 & 0.29 \\
\hline Crown of Aragon & 50 & 0.22 & 0.42 & 0.00 & 1.00 & 45 & 0.24 & 0.43 & 0.00 & 1.00 \\
\hline Distance from London & 50 & 14.06 & 0.24 & 13.76 & 14.89 & 45 & 14.09 & 0.23 & 13.81 & 14.89 \\
\hline Distance from Paris & 50 & 13.88 & 0.28 & 13.50 & 14.85 & 45 & 13.91 & 0.28 & 13.53 & 14.85 \\
\hline Distance from Mainz & 50 & 14.17 & 0.23 & 13.79 & 14.99 & 45 & 14.19 & 0.23 & 13.79 & 14.99 \\
\hline Distance from Madrid & 50 & 12.54 & 0.78 & 8.91 & 14.41 & 45 & 12.52 & 0.82 & 8.91 & 14.41 \\
\hline Distance to the coast & 50 & 1.10 & 0.94 & 0.00 & 3.30 & 45 & 1.19 & 0.95 & 0.00 & 3.30 \\
\hline Humidity & 50 & 66.84 & 5.29 & 57.00 & 78.00 & 45 & 65.87 & 4.57 & 57.00 & 78.00 \\
\hline Temperature & 50 & 14.64 & 2.82 & 10.10 & 21.20 & 45 & 14.80 & 2.91 & 10.10 & 21.20 \\
\hline Rainfall & 50 & 575.28 & 320.77 & 134.00 & $1,691.00$ & 45 & 511.24 & 254.24 & 134.00 & $1,691.00$ \\
\hline Island & 50 & 0.06 & 0.24 & 0.00 & 1.00 & 45 & 0.07 & 0.25 & 0.00 & 1.00 \\
\hline Latitude & 50 & 40.12 & 3.14 & 28.30 & 43.29 & 45 & 39.79 & 3.13 & 28.30 & 43.13 \\
\hline Land suitability for cotton & 50 & 668.20 & 761.35 & 0.00 & $2,379.11$ & 45 & 742.44 & 767.56 & 0.00 & $2,379.11$ \\
\hline Land suitability for sugar & 50 & 2.24 & 7.46 & 0.00 & 34.53 & 45 & 2.49 & 7.83 & 0.00 & 34.53 \\
\hline Land suitability for tobacco & 50 & $1,327.79$ & 528.66 & 171.52 & $2,681.86$ & 45 & $1,371.44$ & 528.30 & 171.52 & $2,681.86$ \\
\hline Madrid & 50 & 0.02 & 0.14 & 0.00 & 1.00 & 45 & 0.02 & 0.15 & 0.00 & 1.00 \\
\hline Mediterranean Sea & 50 & 0.22 & 0.42 & 0.00 & 1.00 & 45 & 0.24 & 0.43 & 0.00 & 1.00 \\
\hline Atlantic Ocean & 50 & 0.12 & 0.33 & 0.00 & 1.00 & 45 & 0.13 & 0.34 & 0.00 & 1.00 \\
\hline Cantabrian Sea & 50 & 0.10 & 0.30 & 0.00 & 1.00 & 45 & 0.02 & 0.15 & 0.00 & 1.00 \\
\hline Roman roads density & 50 & 27.04 & 14.06 & 0.00 & 56.45 & 45 & 28.91 & 13.18 & 0.00 & 56.45 \\
\hline Ruggedness & 50 & 0.52 & 0.34 & 0.06 & 1.36 & 45 & 0.49 & 0.34 & 0.06 & 1.36 \\
\hline Soil quality & 50 & 0.54 & 0.20 & 0.00 & 1.00 & 45 & 0.55 & 0.20 & 0.00 & 1.00 \\
\hline Urban population density in 800 & 50 & 0.47 & 1.72 & 0.00 & 11.62 & 45 & 0.52 & 1.81 & 0.00 & 11.62 \\
\hline Urban population density at conquest & 50 & 0.99 & 1.97 & 0.00 & 7.91 & 45 & 1.10 & 2.04 & 0.00 & 7.91 \\
\hline Wooded steppe (\% area) & 50 & 0.38 & 0.46 & 0.00 & 1.00 & 45 & 0.32 & 0.44 & 0.00 & 1.00 \\
\hline Years since transition to agriculture & 50 & $7,445.23$ & 34.04 & $7,339.11$ & $7,530.39$ & 45 & $7,444.77$ & 35.68 & $7,339.11$ & $7,530.39$ \\
\hline
\end{tabular}




\begin{tabular}{|c|c|c|c|c|c|c|c|c|c|c|}
\hline \multirow[b]{2}{*}{ Variable } & \multicolumn{5}{|c|}{ Full sample } & \multicolumn{5}{|c|}{ Excluding the initial resistance area } \\
\hline & Obs & Mean & Std. Dev. & Min & $\operatorname{Max}$ & Obs & Mean & Std. Dev. & Min & $\operatorname{Max}$ \\
\hline \multicolumn{11}{|c|}{ Variables of pre-Reconquest development (not described above) } \\
\hline Ancient settlements over surface area & 48 & 1.30 & 1.14 & 0.25 & 5.93 & 43 & 1.23 & 0.95 & 0.25 & 4.17 \\
\hline City population in 800 & 50 & 6.50 & 23.84 & 0.00 & 160.00 & 45 & 7.22 & 25.05 & 0.00 & 160.00 \\
\hline $\begin{array}{l}\text { Coinage of imperial Roman coins over } \\
\text { surface area }\end{array}$ & 50 & 0.06 & 0.09 & 0.00 & 0.40 & 45 & 0.06 & 0.09 & 0.00 & 0.40 \\
\hline $\begin{array}{l}\text { Number of bishoprics circa } 600 \text { over } \\
\text { surface area }\end{array}$ & 50 & 0.11 & 0.11 & 0.00 & 0.39 & 45 & 0.12 & 0.11 & 0.00 & 0.39 \\
\hline Roman roads density: Main roads & 50 & 6.28 & 7.04 & 0.00 & 30.22 & 45 & 6.98 & 7.09 & 0.00 & 30.22 \\
\hline Roman villas over surface area & 48 & 0.27 & 0.29 & 0.00 & 1.57 & 43 & 0.28 & 0.30 & 0.00 & 1.57 \\
\hline \multicolumn{11}{|c|}{ Variables used in the balancedness table (not described above) } \\
\hline $\begin{array}{l}\text { Urbanization levels (Density of urban } \\
\text { population): } 800\end{array}$ & 50 & 0.47 & 1.72 & 0.00 & 11.62 & 45 & 0.52 & 1.81 & 0.00 & 11.62 \\
\hline $\begin{array}{l}\text { Urbanization levels (Density of urban } \\
\text { population): } 900\end{array}$ & 50 & 0.76 & 3.19 & 0.00 & 22.15 & 45 & 0.85 & 3.35 & 0.00 & 22.15 \\
\hline $\begin{array}{l}\text { Urbanization levels (Density of urban } \\
\text { population): } 1000\end{array}$ & 50 & 1.53 & 4.78 & 0.00 & 32.68 & 45 & 1.70 & 5.01 & 0.00 & 32.68 \\
\hline $\begin{array}{l}\text { Urbanization levels (Density of urban } \\
\text { population): } 1200\end{array}$ & 50 & 1.02 & 1.71 & 0.00 & 6.84 & 45 & 1.13 & 1.77 & 0.00 & 6.84 \\
\hline $\begin{array}{l}\text { Urbanization levels (Density of urban } \\
\text { population): } 1300\end{array}$ & 50 & 1.64 & 2.37 & 0.00 & 11.86 & 45 & 1.80 & 2.44 & 0.00 & 11.86 \\
\hline $\begin{array}{l}\text { Urbanization levels (Density of urban } \\
\text { population): } 1400\end{array}$ & 50 & 1.53 & 1.92 & 0.00 & 7.91 & 45 & 1.67 & 1.97 & 0.00 & 7.91 \\
\hline $\begin{array}{l}\text { Urbanization levels (Density of urban } \\
\text { population): } 1500\end{array}$ & 50 & 1.72 & 1.99 & 0.00 & 8.26 & 45 & 1.91 & 2.01 & 0.00 & 8.26 \\
\hline $\begin{array}{l}\text { Urbanization levels (Density of urban } \\
\text { population): } 1600\end{array}$ & 50 & 2.97 & 3.48 & 0.00 & 16.24 & 45 & 3.22 & 3.57 & 0.00 & 16.24 \\
\hline $\begin{array}{l}\text { Urbanization levels (Density of urban } \\
\text { population): } 1700\end{array}$ & 48 & 2.43 & 3.48 & 0.00 & 17.44 & 43 & 2.60 & 3.62 & 0.00 & 17.44 \\
\hline $\begin{array}{l}\text { Urbanization levels (Density of urban } \\
\text { population): } 1800\end{array}$ & 50 & 6.04 & 6.70 & 0.00 & 29.59 & 45 & 6.25 & 7.01 & 0.00 & 29.59 \\
\hline $\begin{array}{l}\text { Urbanization levels (Density of urban } \\
\text { population): } 1850\end{array}$ & 50 & 8.53 & 9.72 & 0.47 & 41.92 & 45 & 8.76 & 10.22 & 0.47 & 41.92 \\
\hline Agricultural output per $\mathrm{km} 2$ in 1860 & 50 & $5,066.42$ & $3,118.14$ & $1,490.59$ & $16,929.11$ & 45 & $5,042.61$ & $3,178.96$ & $1,490.59$ & $16,929.11$ \\
\hline Agricultural output per capita in 1860 & 50 & 147.70 & 58.40 & 33.97 & 369.67 & 45 & 153.75 & 57.89 & 33.97 & 369.67 \\
\hline Agricultural productivity in 1860 & 50 & 653.31 & 252.33 & 122.50 & $1,582.16$ & 45 & 671.80 & 255.63 & 122.50 & $1,582.16$ \\
\hline $\begin{array}{l}\text { Agricultural share over GDP (\%) in } \\
1860\end{array}$ & 50 & 42.81 & 12.90 & 8.16 & 72.28 & 45 & 44.02 & 12.57 & 8.16 & 72.28 \\
\hline Productive land (\%) in 1900 & 48 & 0.94 & 0.05 & 0.75 & 1.00 & 43 & 0.95 & 0.04 & 0.87 & 1.00 \\
\hline Wheat output per hectare in 1916 & 50 & 23.22 & 4.09 & 17.20 & 35.20 & 45 & 23.31 & 4.17 & 17.20 & 35.20 \\
\hline Agricultural output per ha in 1950 & 50 & $1,155.65$ & 497.91 & 404.14 & $2,663.76$ & 45 & $1,153.19$ & 518.19 & 404.14 & $2,663.76$ \\
\hline \multicolumn{11}{|c|}{ Variables Used in Section VI on the Timing of the Effects (not described above) } \\
\hline Relative GDP per capita in 1860 & 50 & 1.00 & 0.32 & 0.22 & 1.91 & 45 & 1.00 & 0.33 & 0.22 & 1.88 \\
\hline Relative GDP per capita in 1930 & 50 & 1.00 & 0.39 & 0.55 & 2.32 & 45 & 1.00 & 0.37 & 0.57 & 2.44 \\
\hline Relative GDP per capita in 1971 & 50 & 1.00 & 0.28 & 0.61 & 1.57 & 45 & 1.00 & 0.26 & 0.64 & 1.62 \\
\hline Relative GDP per capita in 2005 & 50 & 1.00 & 0.20 & 0.68 & 1.49 & 45 & 1.00 & 0.19 & 0.70 & 1.43 \\
\hline $\begin{array}{l}\text { Relative industrial output per capita in } \\
1860\end{array}$ & 50 & 1.00 & 0.58 & 0.23 & 3.44 & 45 & 1.00 & 0.59 & 0.22 & 3.35 \\
\hline $\begin{array}{l}\text { Relative industrial output per capita in } \\
1930\end{array}$ & 50 & 1.00 & 0.79 & 0.24 & 3.73 & 45 & 1.00 & 0.72 & 0.28 & 4.34 \\
\hline $\begin{array}{l}\text { Relative industrial output per capita in } \\
1970\end{array}$ & 50 & 1.00 & 0.63 & 0.28 & 3.08 & 45 & 1.00 & 0.50 & 0.33 & 2.79 \\
\hline $\begin{array}{l}\text { Relative industrial output per capita in } \\
2005\end{array}$ & 50 & 1.00 & 0.56 & 0.24 & 2.83 & 45 & 1.00 & 0.51 & 0.26 & 2.25 \\
\hline
\end{tabular}




\begin{tabular}{|c|c|c|c|c|c|c|c|c|c|c|}
\hline \multirow[b]{2}{*}{ Variable } & \multicolumn{5}{|c|}{ Full sample } & \multicolumn{5}{|c|}{ Excluding the initial resistance area } \\
\hline & Obs & Mean & Std. Dev. & Min & Max & Obs & Mean & Std. Dev. & Min & Max \\
\hline \multicolumn{11}{|l|}{ Variables used as mechanisms } \\
\hline Family types & 50 & 0.99 & 0.07 & 0.87 & 1.19 & 45 & 0.99 & 0.07 & 0.87 & 1.19 \\
\hline Moorish ancestry & 48 & 8.76 & 8.01 & 0.00 & 21.70 & 43 & 9.53 & 7.98 & 0.00 & 21.70 \\
\hline $\begin{array}{l}\text { Religiosity (Clerical population in } \\
\text { 1797) }\end{array}$ & 50 & 0.02 & 0.00 & 0.01 & 0.03 & 45 & 0.02 & 0.00 & 0.01 & 0.03 \\
\hline Land concentration in 1962 & 50 & 12.63 & 12.56 & 0.00 & 46.30 & 45 & 14.01 & 12.50 & 0.00 & 46.30 \\
\hline Land Gini Index in 1972 & 50 & 71.22 & 10.08 & 50.39 & 87.51 & 45 & 72.73 & 9.37 & 50.39 & 87.51 \\
\hline $\begin{array}{l}\text { Percentage of landless workers in } \\
1797\end{array}$ & 50 & 47.99 & 21.27 & 3.74 & 85.77 & 45 & 51.50 & 19.15 & 17.42 & 85.77 \\
\hline $\begin{array}{l}\text { Percentage of landless workers in } \\
1956\end{array}$ & 50 & 31.08 & 20.29 & 2.76 & 73.05 & 45 & 33.60 & 19.74 & 6.54 & 73.05 \\
\hline $\begin{array}{l}\text { Percentage of population entities under } \\
\text { Church jurisdiction in } 1787\end{array}$ & 50 & 7.99 & 11.27 & 0.00 & 45.90 & 45 & 8.65 & 11.66 & 0.00 & 45.90 \\
\hline $\begin{array}{l}\text { Percentage of population entities under } \\
\text { seigneurial jurisdiction in } 1787\end{array}$ & 50 & 48.31 & 23.79 & 0.00 & 90.00 & 45 & 48.86 & 23.48 & 0.00 & 90.00 \\
\hline $\begin{array}{l}\text { Market fragmentation (Road density in } \\
1760 \text { ) }\end{array}$ & 50 & 0.02 & 0.01 & 0.00 & 0.06 & 45 & 0.02 & 0.01 & 0.00 & 0.06 \\
\hline \multicolumn{11}{|l|}{ Outcomes variables in the $1860 \mathrm{~s}$} \\
\hline Convicts & 50 & 1.50 & 0.70 & 0.43 & 3.35 & 45 & 1.58 & 0.68 & 0.44 & 3.35 \\
\hline Crimes & 50 & 2.28 & 0.95 & 0.63 & 5.20 & 45 & 2.40 & 0.91 & 0.82 & 5.20 \\
\hline Infant mortality & 50 & 249.41 & 52.47 & 131.58 & 344.72 & 45 & 259.27 & 44.90 & 131.79 & 344.72 \\
\hline Life expectancy & 50 & 29.82 & 5.09 & 19.68 & 45.88 & 45 & 29.31 & 4.94 & 19.68 & 45.88 \\
\hline Literacy rate & 50 & 27.40 & 10.71 & 14.00 & 53.00 & 45 & 26.18 & 9.98 & 14.00 & 51.00 \\
\hline Percentage of voters & 50 & 0.06 & 0.02 & 0.02 & 0.13 & 45 & 0.06 & 0.02 & 0.02 & 0.11 \\
\hline Percentage of electors & 50 & 0.11 & 0.03 & 0.06 & 0.21 & 45 & 0.11 & 0.03 & 0.06 & 0.21 \\
\hline School enrollment & 50 & 0.23 & 0.08 & 0.08 & 0.42 & 45 & 0.22 & 0.08 & 0.08 & 0.39 \\
\hline \multicolumn{11}{|l|}{ Variables at municipal level } \\
\hline Altitude & 8,107 & 613.90 & 343.79 & 0.00 & $1,695.00$ & 7,652 & 636.65 & 336.08 & 0.00 & $1,695.00$ \\
\hline Annual average temperature & 8,191 & 127.48 & 24.78 & 24.00 & 196.00 & 7,729 & 127.80 & 25.24 & 24.00 & 196.00 \\
\hline Annual rainfall & 8,191 & 604.80 & 225.78 & 113.00 & $1,522.00$ & 7,729 & 576.62 & 196.59 & 113.00 & $1,522.00$ \\
\hline $\begin{array}{l}\text { Average number of vehicles per } \\
\text { household }\end{array}$ & 8,098 & 0.96 & 0.28 & 0.00 & 2.51 & 7,644 & 0.95 & 0.28 & 0.00 & 2.51 \\
\hline Average socioeconomic condition & 8,098 & 95.12 & 14.99 & 31.00 & 186.00 & 7,644 & 94.60 & 15.09 & 31.00 & 186.00 \\
\hline Distance to Madrid & 8,191 & 290.75 & 202.05 & 0.00 & $1,950.28$ & 7,729 & 288.56 & 207.68 & 0.00 & $1,950.28$ \\
\hline Distance to the coast & 8,191 & 131.99 & 98.88 & 0.03 & 370.87 & 7,729 & 138.69 & 97.76 & 0.03 & 370.87 \\
\hline Distance to the nearest capital & 8,191 & 44.13 & 24.41 & 0.00 & 230.53 & 7,729 & 45.02 & 24.50 & 0.00 & 230.53 \\
\hline Excess salts & 8,047 & 0.03 & 0.11 & 0.00 & 1.00 & 7,674 & 0.03 & 0.11 & 0.00 & 1.00 \\
\hline $\begin{array}{l}\text { High rate of Reconquest (> provincial } \\
\text { average) }\end{array}$ & 8,191 & 0.44 & 0.50 & 0.00 & 1.00 & 7,729 & 0.47 & 0.50 & 0.00 & 1.00 \\
\hline $\begin{array}{l}\text { High rate of Reconquest (> } \\
1.25^{*} \text { provincial average) }\end{array}$ & 8,191 & 0.20 & 0.40 & 0.00 & 1.00 & 7,729 & 0.21 & 0.40 & 0.00 & 1.00 \\
\hline Labor force activity rate & 8,098 & 74.36 & 7.09 & 27.27 & 100.00 & 7,644 & 74.34 & 7.17 & 27.27 & 100.00 \\
\hline Latitude & 8,107 & 40.73 & 2.11 & 27.70 & 43.74 & 7,652 & 40.59 & 2.08 & 27.70 & 43.74 \\
\hline Nutrient availability & 8,047 & 0.08 & 0.16 & 0.00 & 1.00 & 7,674 & 0.08 & 0.16 & 0.00 & 1.00 \\
\hline Nutrient retention capacity & 8,047 & 0.05 & 0.13 & 0.00 & 1.00 & 7,674 & 0.05 & 0.13 & 0.00 & 1.00 \\
\hline Oxygen availability to roots & 8,047 & 0.01 & 0.06 & 0.00 & 1.00 & 7,674 & 0.01 & 0.06 & 0.00 & 1.00 \\
\hline Population & 8,098 & 6.54 & 1.75 & 1.95 & 14.89 & 7,644 & 6.49 & 1.75 & 1.95 & 14.89 \\
\hline Provincial capital dummy & 8,191 & 0.01 & 0.08 & 0.00 & 1.00 & 7,729 & 0.01 & 0.08 & 0.00 & 1.00 \\
\hline Rate of Reconquest & 8,191 & 5.90 & 5.32 & 0.00 & 22.66 & 7,729 & 6.25 & 5.27 & 0.29 & 22.66 \\
\hline Rooting conditions & 8,047 & 0.37 & 0.27 & 0.00 & 1.00 & 7,674 & 0.36 & 0.27 & 0.00 & 1.00 \\
\hline Soil quality & 8,047 & 0.83 & 0.11 & 0.00 & 1.00 & 7,674 & 0.83 & 0.11 & 0.00 & 1.00 \\
\hline Toxicity & 8,047 & 0.04 & 0.11 & 0.00 & 1.00 & 7,674 & 0.04 & 0.11 & 0.00 & 1.00 \\
\hline Workability & 8,047 & 0.35 & 0.21 & 0.00 & 1.00 & 7,674 & 0.34 & 0.21 & 0.00 & 1.00 \\
\hline
\end{tabular}




\section{Appendix C. The effect of rate of Reconquest: Alternative functional forms.}

TABLE A3 - THE EFFECT OF RATE OF RECONQUEST: ALTERNATIVE FUNCTIONAL FORMS

\begin{tabular}{|c|c|c|c|}
\hline \multicolumn{4}{|c|}{ Dependent variable is log GDP per capita in 2005} \\
\hline & $\begin{array}{l}\text { Quadratic polynomial in rate } \\
\text { of Reconquest }\end{array}$ & Log of rate of Reconquest & $\begin{array}{c}\text { Quartile division of rate of } \\
\text { Reconquest }\end{array}$ \\
\hline & (1) & (2) & (3) \\
\hline Rate of Reconquest & $\begin{array}{c}-0.04 * * * \\
(0.014)\end{array}$ & & \\
\hline Rate of Reconquest squared & $\begin{array}{c}0.001^{* *} \\
(0.00)\end{array}$ & & \\
\hline Log of rate of Reconquest & & $\begin{array}{c}-0.142^{* * *} \\
(0.037)\end{array}$ & \\
\hline Second quartile of rate of Reconquest & & & $\begin{array}{l}-0.055 \\
(0.048)\end{array}$ \\
\hline Third quartile of rate of Reconquest & & & $\begin{array}{l}-0.084 \\
(0.063)\end{array}$ \\
\hline Fourth quartile of rate of Reconquest & & & $\begin{array}{c}-0.235^{* * *} \\
(0.049)\end{array}$ \\
\hline Crown of Aragon & $\begin{array}{l}-0.019 \\
(0.089)\end{array}$ & $\begin{array}{l}-0.031 \\
(0.093)\end{array}$ & $\begin{array}{l}-0.022 \\
(0.075)\end{array}$ \\
\hline Madrid & $\begin{array}{l}0.417 * * * \\
(0.026)\end{array}$ & $\begin{array}{l}0.418^{* * *} \\
(0.023)\end{array}$ & $\begin{array}{l}0.386 * * * \\
(0.047)\end{array}$ \\
\hline Rainfall & $\begin{array}{c}0.00 \\
(0.00)\end{array}$ & $\begin{array}{c}0.00 \\
(0.00)\end{array}$ & $\begin{array}{c}0.00 \\
(0.00)\end{array}$ \\
\hline Soil quality & $\begin{array}{l}0.364 * * \\
(0.138)\end{array}$ & $\begin{array}{c}0.375^{* * * *} \\
(0.136)\end{array}$ & $\begin{array}{l}0.323^{* *} \\
(0.135)\end{array}$ \\
\hline Ruggedness & $\begin{array}{c}0.211^{* *} \\
(0.1)\end{array}$ & $\begin{array}{l}0.214 * * \\
(0.102)\end{array}$ & $\begin{array}{c}0.239 * * \\
(0.09)\end{array}$ \\
\hline Mediterranean Sea & $\begin{array}{c}-0.01 \\
(0.049)\end{array}$ & $\begin{array}{l}-0.008 \\
(0.05)\end{array}$ & $\begin{array}{l}-0.014 \\
(0.058)\end{array}$ \\
\hline Cantabrian Sea & $\begin{array}{l}-0.018 \\
(0.043)\end{array}$ & $\begin{array}{l}-0.01 \\
(0.042)\end{array}$ & $\begin{array}{l}-0.038 \\
(0.056)\end{array}$ \\
\hline Border with Portugal & $\begin{array}{l}-0.038 \\
(0.045)\end{array}$ & $\begin{array}{c}-0.03 \\
(0.046)\end{array}$ & $\begin{array}{l}-0.045 \\
(0.044)\end{array}$ \\
\hline Ln distance from Paris & $\begin{array}{l}-0.297 * * \\
(0.122)\end{array}$ & $\begin{array}{l}-0.315 * * \\
(0.117)\end{array}$ & $\begin{array}{c}-0.361 * * * \\
(0.112)\end{array}$ \\
\hline Coal dummy in 1860 & $\begin{array}{c}0.045 \\
(0.038)\end{array}$ & $\begin{array}{c}0.04 \\
(0.043)\end{array}$ & $\begin{array}{c}0.043 \\
(0.043)\end{array}$ \\
\hline$R^{2}$ & 0.78 & 0.77 & 0.78 \\
\hline Number of observations & 45 & 45 & 45 \\
\hline
\end{tabular}




\section{Appendix D. Replication of tables 1 and 2 using the full sample of 50 Spanish provinces.}

Dependent variable is log GDP per capita in 2005

\begin{tabular}{|c|c|c|c|c|c|c|c|c|c|c|}
\hline & $\begin{array}{c}\text { Rate of } \\
\text { Reconquest }\end{array}$ & $\begin{array}{l}\text { Additional } \\
\text { control }\end{array}$ & $R^{2}$ & $N$ & & & $\begin{array}{c}\text { Rate of } \\
\text { Reconquest }\end{array}$ & $\begin{array}{l}\text { Additional } \\
\text { control }\end{array}$ & $R^{2}$ & $N$ \\
\hline \multicolumn{5}{|l|}{ A: Basic relationship } & \multirow{2}{*}{\multicolumn{6}{|c|}{ Climatic, geographic and topographic factors (Continued) }} \\
\hline (1) 50 provinces & $\begin{array}{c}-0.018 * * * \\
(0.004)\end{array}$ & & 0.3 & $\overline{50}$ & & & & & & \\
\hline $\begin{array}{l}\text { (2) Initial resistance } \\
\text { provinces removed }\end{array}$ & $\begin{array}{c}-0.017 * * * \\
(0.004)\end{array}$ & & 0.3 & 45 & $(20)$ & Average altitude & $\begin{array}{c}-0.019 * * * \\
(0.004)\end{array}$ & $\begin{array}{c}-0.0001^{*} \\
(0.00)\end{array}$ & 0.3 & 50 \\
\hline \multicolumn{5}{|c|}{ B: Neolithic and Historical controls } & $(21)$ & Ruggedness & $-0.019 * * *$ & 0.097 & 0.3 & 50 \\
\hline $\begin{array}{l}\text { (3) Wooded steppe (\% } \\
\text { area) }\end{array}$ & $\begin{array}{c}-0.019 * * * \\
(0.004)\end{array}$ & $\begin{array}{l}-0.046 \\
(0.055)\end{array}$ & 0.3 & 50 & \multicolumn{5}{|c|}{ D: Geographic controls related to transportation costs } & \\
\hline $\begin{array}{l}\text { (4) Years since } \\
\text { transition to }\end{array}$ & $\begin{array}{c}-0.018 * * * \\
(0.004)\end{array}$ & $\begin{array}{c}0.000 \\
(0.001)\end{array}$ & 0.3 & 50 & $(22)$ & Mediterranean Sea & $\begin{array}{c}-0.019 * * * \\
(0.004)\end{array}$ & $\begin{array}{c}0.079 \\
(0.055)\end{array}$ & 0.3 & 50 \\
\hline (5) Roman roads density & $\begin{array}{c}-0.019 * * * \\
(0.004)\end{array}$ & $\begin{array}{c}0.000 \\
(0.002)\end{array}$ & 0.3 & 50 & $(23)$ & Atlantic Ocean & $\begin{array}{c}-0.018 * * * \\
(0.004)\end{array}$ & $\begin{array}{l}-0.026 \\
(0.059)\end{array}$ & 0.3 & 50 \\
\hline $\begin{array}{l}\text { (6) Urban population } \\
\text { density in } 800\end{array}$ & $\begin{array}{c}-0.017 * * * \\
(0.004)\end{array}$ & $\begin{array}{c}-0.015 * * \\
(0.007)\end{array}$ & 0.3 & 50 & $(24)$ & Cantabrian Sea & $\begin{array}{c}-0.019 * * * \\
(0.004)\end{array}$ & $\begin{array}{c}-0.02 \\
(0.087)\end{array}$ & 0.3 & 50 \\
\hline $\begin{array}{l}\text { (7) Urban population } \\
\text { density at conquest }\end{array}$ & $\begin{array}{c}-0.017 * * * \\
(0.004)\end{array}$ & $\begin{array}{l}-0.007 \\
(0.015)\end{array}$ & 0.3 & 50 & $(25)$ & Island & $\begin{array}{c}-0.019 * * * \\
(0.004)\end{array}$ & $\begin{array}{c}0.08 \\
(0.066)\end{array}$ & 0.3 & 50 \\
\hline $\begin{array}{l}\text { (8) Av. urban pop.dens. at } \\
\text { conquest in the } \\
\text { Christian kingdom }\end{array}$ & $\begin{array}{c}-0.019 * * * \\
(0.004)\end{array}$ & $\begin{array}{c}0.014 \\
(0.053)\end{array}$ & 0.3 & 50 & $(26)$ & Coast Dummy & $\begin{array}{c}-0.018 * * * \\
(0.004)\end{array}$ & $\begin{array}{c}0.038 \\
(0.048)\end{array}$ & 0.3 & 50 \\
\hline $\begin{array}{l}\text { (9) Centuries under } \\
\text { Muslim domination }\end{array}$ & $\begin{array}{c}-0.016 * * * \\
(0.004)\end{array}$ & $\begin{array}{c}-0.01 \\
(0.011)\end{array}$ & 0.3 & 50 & $(27)$ & $\begin{array}{l}\text { Coast length/ } \\
\text { surface area }\end{array}$ & $\begin{array}{c}-0.018 * * * \\
(0.004)\end{array}$ & $\begin{array}{c}0.329 \\
(0.307)\end{array}$ & 0.3 & 50 \\
\hline (10) Crown of Aragon & $\begin{array}{c}-0.016 * * * \\
(0.004)\end{array}$ & $\begin{array}{c}0.139 * * * \\
(0.044)\end{array}$ & 0.4 & 50 & $(28)$ & $\begin{array}{l}\text { Distance to the } \\
\text { coast }\end{array}$ & $\begin{array}{c}-0.018 * * * \\
(0.003)\end{array}$ & $\begin{array}{l}-0.047 * \\
(0.028)\end{array}$ & 0.4 & 50 \\
\hline (11) Madrid & $\begin{array}{c}-0.018 * * * \\
(0.004)\end{array}$ & $\begin{array}{c}0.356^{* * *} \\
(0.023)\end{array}$ & 0.4 & 50 & (29) & $\begin{array}{l}\text { Border with } \\
\text { Portugal }\end{array}$ & $\begin{array}{c}-0.016^{* * *} \\
(0.004)\end{array}$ & $\begin{array}{c}-0.164 * * * \\
(0.054)\end{array}$ & 0.4 & 50 \\
\hline \multicolumn{5}{|c|}{ C: Climatic, geographic and topographic factors } & $(30)$ & Ln distance from & $-0.018 * * *$ & -0.014 & 0.3 & 50 \\
\hline (12) Latitude & $-0.017 * * *$ & 0.006 & 0.3 & 50 & & & $(0.004)$ & $(0.041)$ & & \\
\hline & $(0.004)$ & $(0.006)$ & & & $(31)$ & Ln distance from & $-0.014 * * *$ & -0.199 & 0.3 & 50 \\
\hline (13) Temperature & $\begin{array}{c}-0.02 * * * \\
(0.004)\end{array}$ & $\begin{array}{c}0.005 \\
(0.007)\end{array}$ & 0.3 & 50 & $(32)$ & $\begin{array}{l}\text { London } \\
\text { Ln distance from }\end{array}$ & $\begin{array}{c}(0.004) \\
-0.011 * *\end{array}$ & $\begin{array}{l}(0.121) \\
-0.262 *\end{array}$ & 0.4 & 50 \\
\hline (14) Rainfall & $\begin{array}{c}-0.019 * * * \\
(0.004)\end{array}$ & $\begin{array}{c}0.00 \\
(0.00)\end{array}$ & 0.3 & 50 & (33) & $\begin{array}{l}\text { Paris } \\
\text { Ln distance from }\end{array}$ & $\begin{array}{c}(0.005) \\
-0.012 * *\end{array}$ & $\begin{array}{c}(0.135) \\
-0.339 * *\end{array}$ & 0.4 & 50 \\
\hline (15) Humidity & $\begin{array}{c}-0.015^{* * *} \\
(0.005)\end{array}$ & $\begin{array}{c}0.006 \\
(0.007)\end{array}$ & 0.3 & 50 & $E: N c$ & $\begin{array}{l}\text { Mainz } \\
\text { atural resources en }\end{array}$ & $\begin{array}{r}(0.005) \\
\text { dowments }\end{array}$ & $(0.168)$ & & \\
\hline (16) Soil quality & $\begin{array}{c}-0.022 * * * \\
(0.004)\end{array}$ & $\begin{array}{l}0.397 * * * \\
(0.08)\end{array}$ & 0.5 & 50 & (34) & $\begin{array}{l}\text { Agric. land } 1900 \\
(\%)\end{array}$ & $\begin{array}{l}-0.02 * * * \\
(0.005)\end{array}$ & $\begin{array}{c}0.156 \\
(0.193)\end{array}$ & 0.3 & 48 \\
\hline $\begin{array}{l}\text { (17) Land suitability for } \\
\text { sugar }\end{array}$ & $\begin{array}{c}-0.019 * * * \\
(0.004)\end{array}$ & $\begin{array}{c}0.001 \\
(0.002)\end{array}$ & 0.3 & 50 & $(35)$ & $\begin{array}{l}\text { Arable land } 1962 \\
(\%)\end{array}$ & $\begin{array}{c}-0.018 * * * \\
(0.004)\end{array}$ & $\begin{array}{l}-0.069 \\
(0.147)\end{array}$ & 0.3 & 50 \\
\hline $\begin{array}{l}\text { (18) Land suitability for } \\
\text { cotton }\end{array}$ & $\begin{array}{l}-0.02 * * * \\
(0.006)\end{array}$ & $\begin{array}{c}0.00 \\
(0.00)\end{array}$ & 0.3 & 50 & $(36)$ & $\begin{array}{l}\text { Coal dummy in } \\
1860\end{array}$ & $\begin{array}{c}-0.018 * * * \\
(0.004)\end{array}$ & $\begin{array}{c}0.061 \\
(0.053)\end{array}$ & 0.3 & 50 \\
\hline $\begin{array}{l}\text { (19) Land suitability for } \\
\text { tobacco }\end{array}$ & $\begin{array}{c}-0.018 * * * \\
(0.004)\end{array}$ & $\begin{array}{l}0.000 \\
(0.00)\end{array}$ & 0.3 & 50 & (37) & $\begin{array}{l}\text { Coal output in } \\
1860\end{array}$ & $\begin{array}{c}-0.018 * * * \\
(0.004)\end{array}$ & $\begin{array}{c}0.003 \\
(0.005)\end{array}$ & 0.3 & 50 \\
\hline
\end{tabular}

Notes: Variables descriptions are provided in Table 9. The estimations include a constant term, which is omitted for space considerations. Robust standard errors are in parentheses. *,** and *** denote significance at the 10,5 and $1 \%$ level, respectively. 


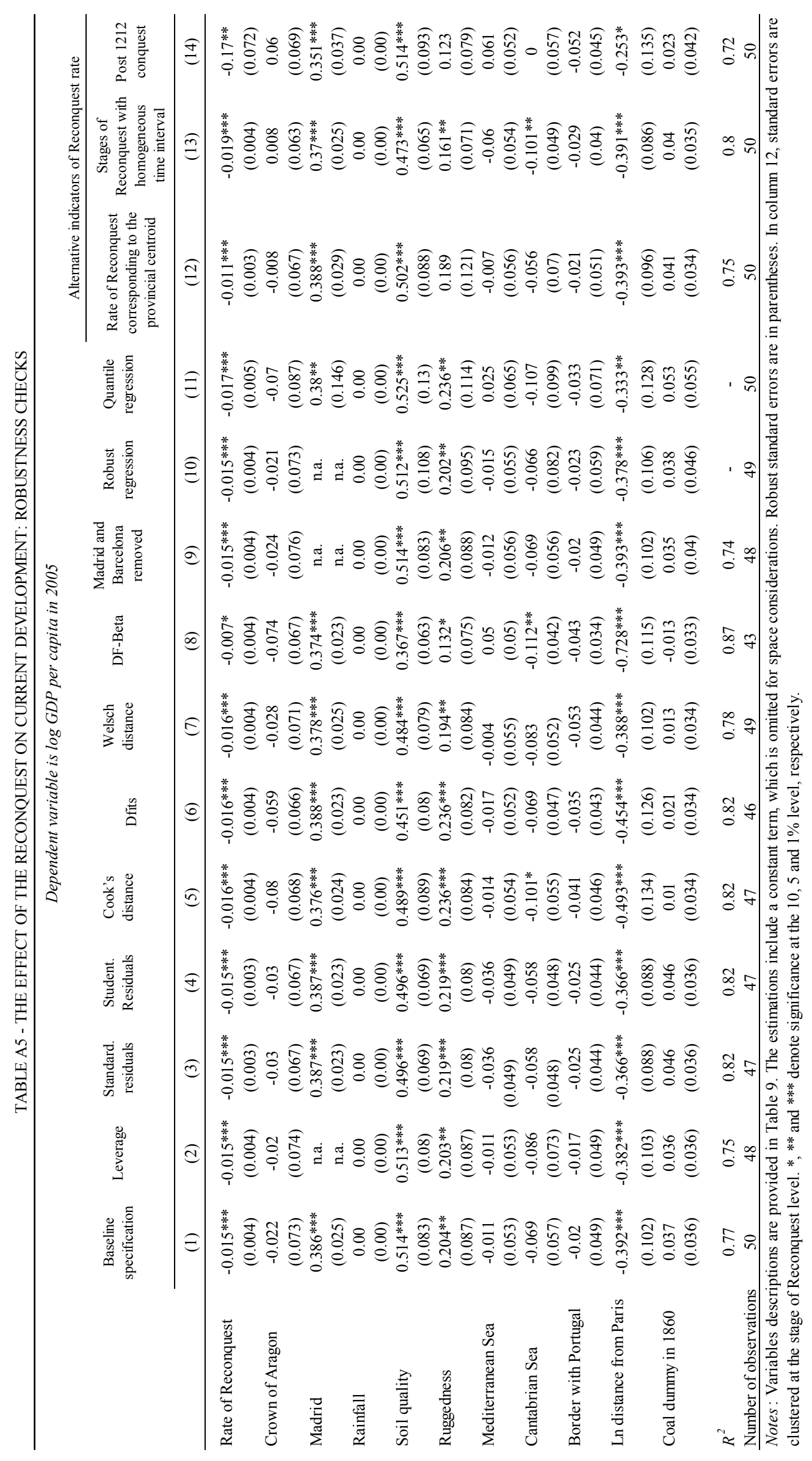




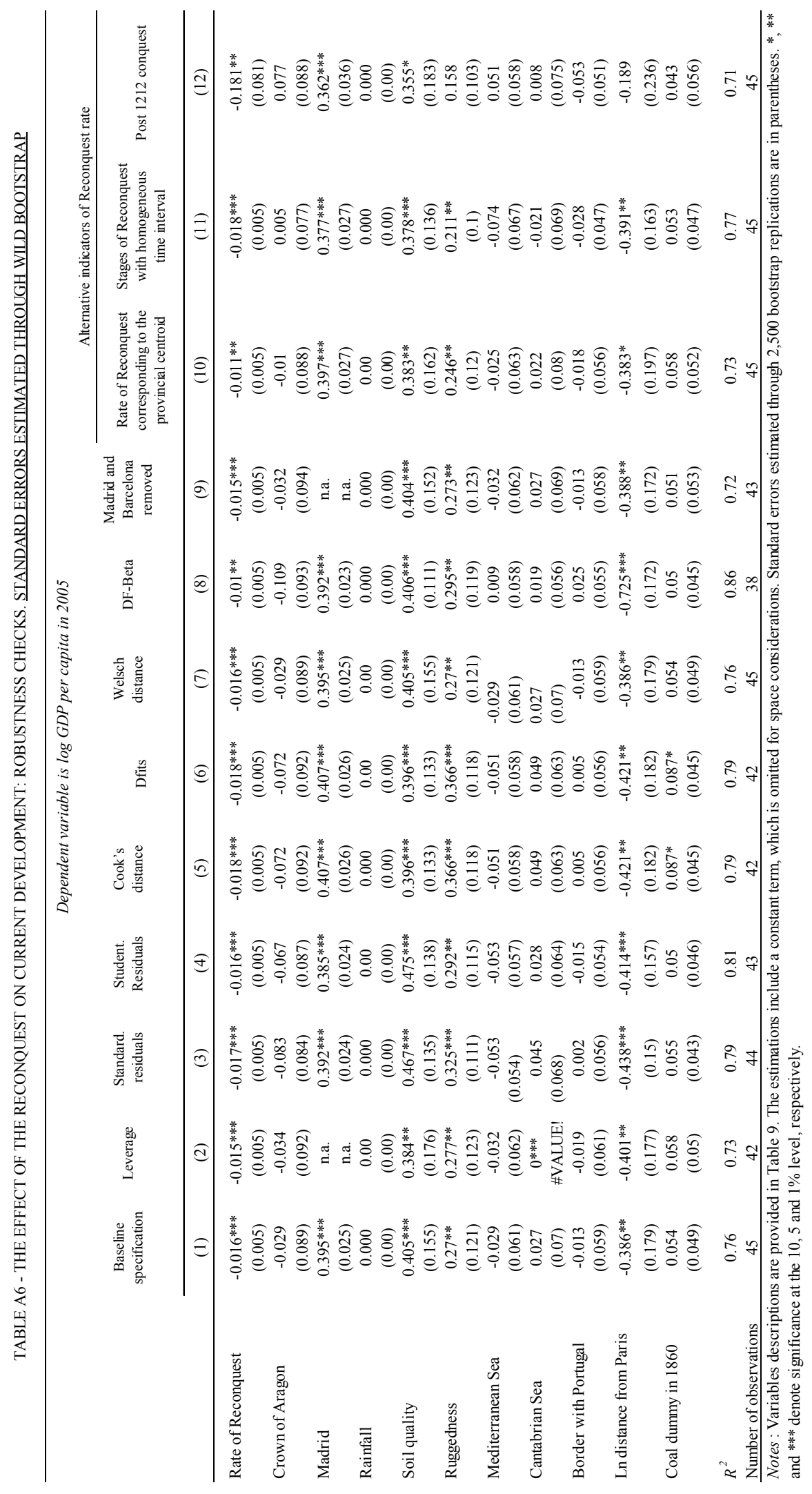




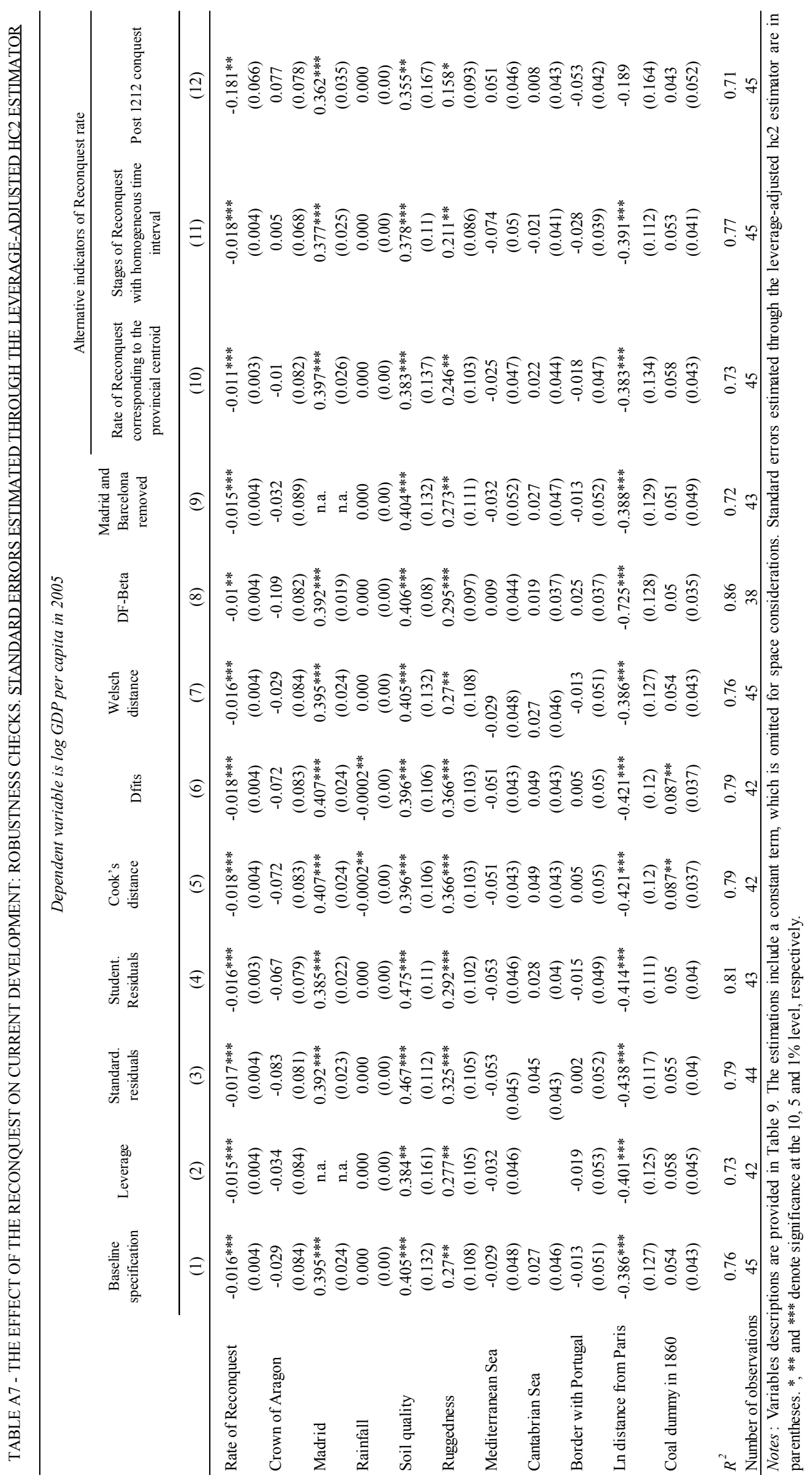



dependence.

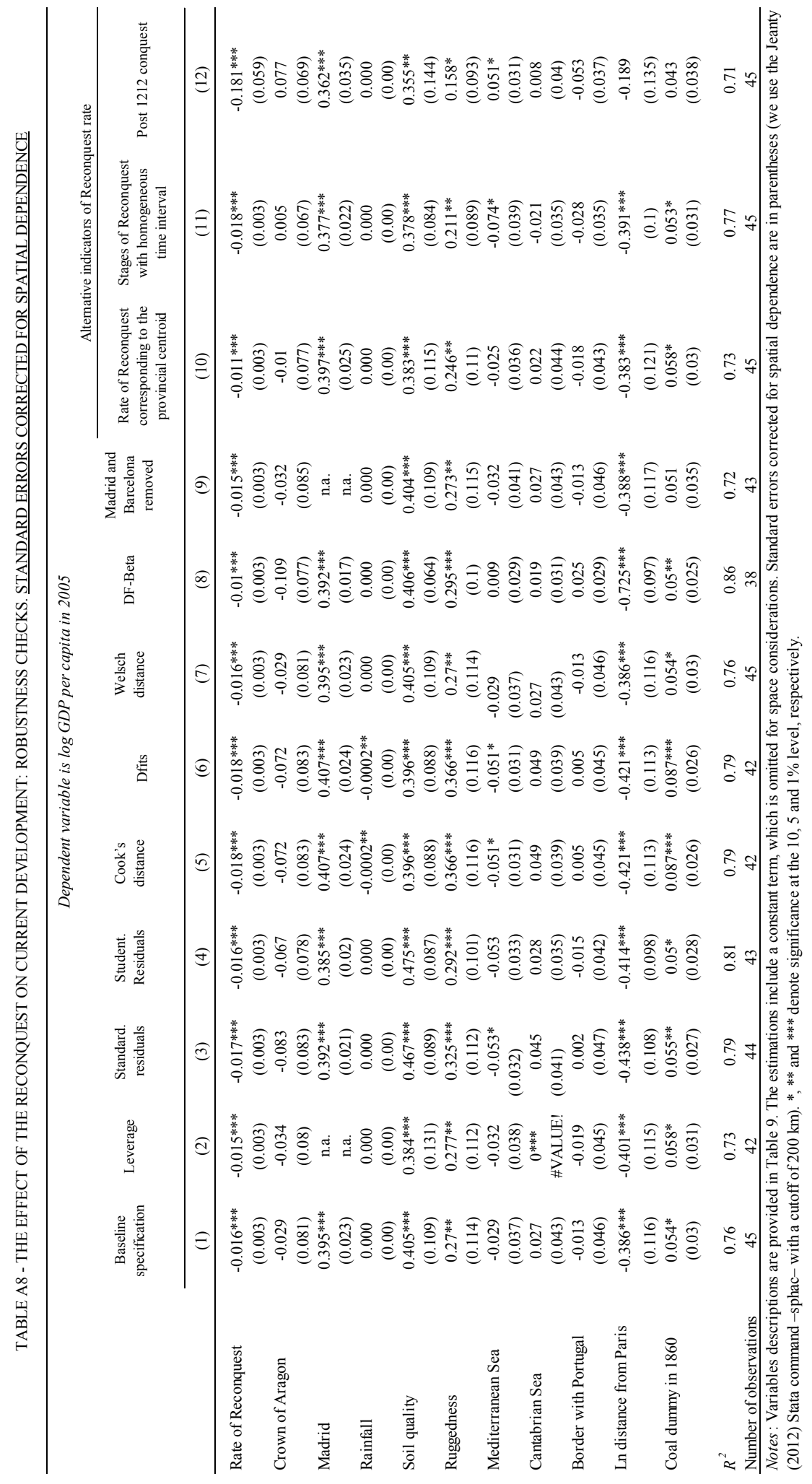


Appendix G. Tackling the North-South gradient issue.

TABLE A9 - THE EFFECT OF THE RECONQUEST ON CURRENT DEVELOPMENT: THE NORTH-SOUTH GRADIENT ISSUE.

\begin{tabular}{|c|c|c|c|c|}
\hline Dependent variable $\rightarrow$ & $\begin{array}{c}\text { Log GDP per capita } \\
\text { in } 2005 \\
\text { (1) }\end{array}$ & $\begin{array}{l}\text { Rate of Reconquest } \\
\text { (2) }\end{array}$ & $\begin{array}{l}\text { Latitude } \\
\text { (3) }\end{array}$ & $\begin{array}{l}\text { Latitude } \\
\text { (4) }\end{array}$ \\
\hline Rate of Reconquest & $\begin{array}{l}-0.008^{*} \\
(0.004)\end{array}$ & & & $\begin{array}{l}0.023 \\
(0.017)\end{array}$ \\
\hline $\begin{array}{l}\text { Residuals of rate of Reconquest from } \\
\text { regression in column ( } 2 \text { ) }\end{array}$ & & & $\begin{array}{c}0.023 \\
(0.171)\end{array}$ & \\
\hline Crown of Aragon & $\begin{array}{l}-0.176^{*} \\
(0.086)\end{array}$ & $\begin{array}{c}-7.649 * * \\
(3.413)\end{array}$ & & $\begin{array}{l}-0.709^{*} \\
(0.348)\end{array}$ \\
\hline Madrid & $\begin{array}{c}0.428^{* * *} \\
(0.029)\end{array}$ & $\begin{array}{l}-0.397 \\
(1.099)\end{array}$ & & $\begin{array}{c}0.083 \\
(0.169)\end{array}$ \\
\hline Rainfall & $\begin{array}{l}0^{* *} \\
(0)\end{array}$ & $\begin{array}{l}-0.01 * \\
(0.005)\end{array}$ & & $\begin{array}{l}0.001^{*} \\
(0.001)\end{array}$ \\
\hline Soil quality & $\begin{array}{l}0.41^{* * *} \\
(0.113)\end{array}$ & $\begin{array}{c}5.963 \\
(4.568)\end{array}$ & & $\begin{array}{c}-3.024 * * * \\
(0.995)\end{array}$ \\
\hline Ruggedness & $\begin{array}{c}0.116 \\
(0.081)\end{array}$ & $\begin{array}{l}9.755^{*} \\
(4.881)\end{array}$ & & $\begin{array}{l}-0.484 \\
(0.54)\end{array}$ \\
\hline Mediterranean Sea & $\begin{array}{c}0.061 \\
(0.064)\end{array}$ & $\begin{array}{l}-0.472 \\
(2.029)\end{array}$ & & $\begin{array}{l}-0.045 \\
(0.258)\end{array}$ \\
\hline Cantabrian Sea & $\begin{array}{c}0.047 \\
(0.061)\end{array}$ & $\begin{array}{l}1.807 \\
(2.516)\end{array}$ & & $\begin{array}{c}0.26 \\
(0.451)\end{array}$ \\
\hline Border with Portugal & $\begin{array}{c}-0.26 * * * \\
(0.082)\end{array}$ & $\begin{array}{c}4.329 \\
(3.154)\end{array}$ & & $\begin{array}{l}0.542^{*} \\
(0.288)\end{array}$ \\
\hline Ln distance from Paris & $\begin{array}{l}10.117 \\
(7.35)\end{array}$ & $\begin{array}{l}-1.163 \\
(6.513)\end{array}$ & & $\begin{array}{c}-10.11 * * * \\
(0.589)\end{array}$ \\
\hline Coal dummy in 1860 & $\begin{array}{c}(1.35) \\
0.015 \\
(0.042)\end{array}$ & $\begin{array}{c}(6.513) \\
0.639 \\
(2.3)\end{array}$ & & $\begin{array}{l}-0.122 \\
(0.224)\end{array}$ \\
\hline Cubic polynomial in latitude and longitude & Yes & & & \\
\hline $\begin{array}{l}R^{2} \\
\text { Number of observations }\end{array}$ & $\begin{array}{c}0.93 \\
45\end{array}$ & $\begin{array}{c}0.45 \\
45\end{array}$ & $\begin{array}{c}0.001 \\
45\end{array}$ & $\begin{array}{c}0.98 \\
45\end{array}$ \\
\hline
\end{tabular}

Notes: Variables descriptions are provided in Table 9. The estimations include a constant term, which is omitted for space considerations. The cubic polynomial takes the form $x+y+x^{2}+y^{2}+x y+x^{3}+y^{3}+x^{2} y+x y^{2}+x^{2} y^{2}$, where $x$ denotes latitude and $y$ denotes longitude. Robust standard errors are in parentheses. ${ }^{*},{ }^{* *}$ and ${ }^{* * *}$ denote significance at the 10,5 and $1 \%$ level, respectively. 


\section{Appendix H. Exploiting variation across the stages of the Reconquest: Aggregating provincial-level data at the stage of Reconquest level.}

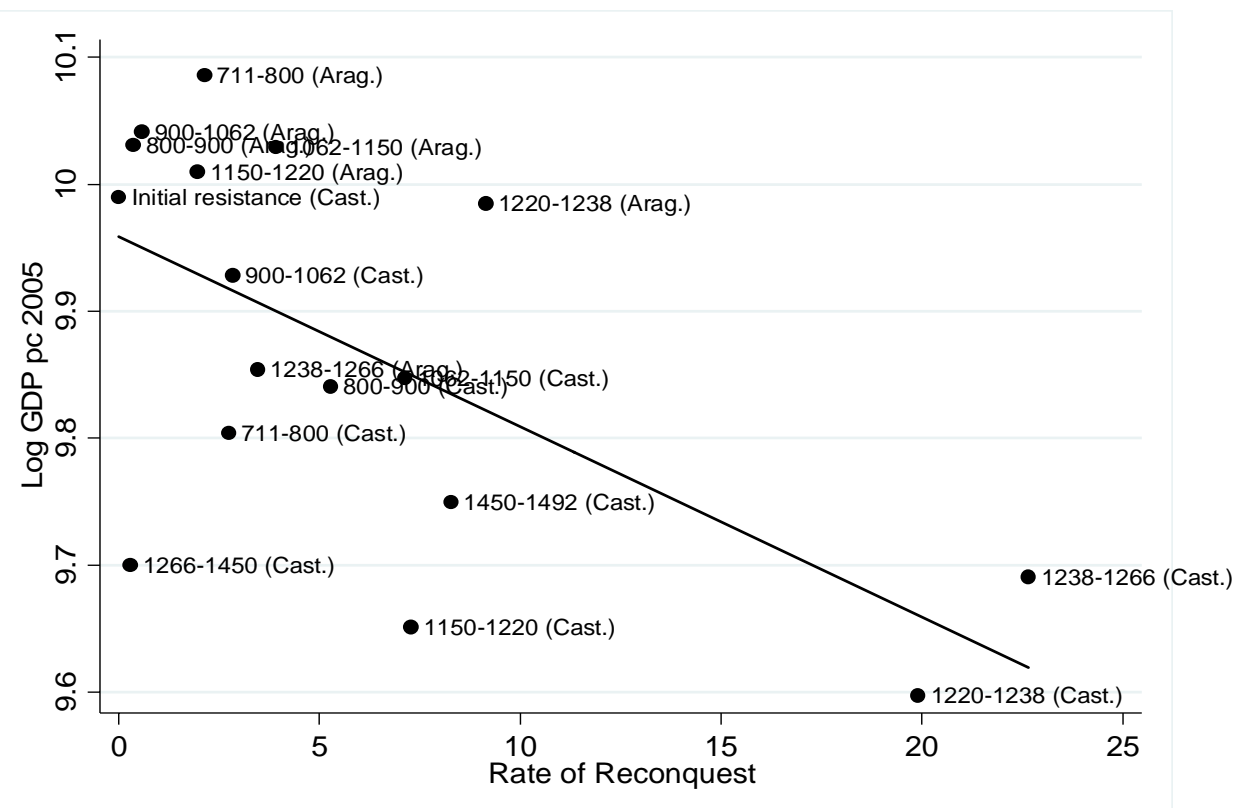

Figure A1. Relationship between current GDP per capita and rate of Reconquest: Aggregating provincial-level data at the stage of Reconquest level.

Notes:

The y-axis variable is the logarithm of the weighted average of output per capita in 2005 for the territory corresponding to each Reconquest stage, using provincial surface area in each stage as weights.

Note that the 1266-1450 Reconquest stage in Castile is a clear outlier caused by the stability of the frontier of Granada over an extended period of time.

TABLE A10 - THE EFFECT OF THE RECONQUEST ON CURRENT DEVELOPMENT: AGGREGATING PROVINCIAL-LEVEL DATA AT THE STAGE OF RECONQUEST LEVEL.

Dependent variable is log GDP per capita in 2005

The whole territory of Spain

Initial resistance area removed

\begin{tabular}{|c|c|c|c|c|}
\hline & \multicolumn{2}{|c|}{ The whole territory of Spain } & \multicolumn{2}{|c|}{ Initial resistance area removed } \\
\hline & (1) & (2) & (3) & (4) \\
\hline \multirow[t]{2}{*}{ Rate of Reconquest } & $-0.015^{* * *}$ & $-0.01 * *$ & $-0.015 * * *$ & $-0.01 * *$ \\
\hline & $(0.004)$ & $(0.004)$ & $(0.004)$ & $(0.004)$ \\
\hline \multirow{2}{*}{$\begin{array}{l}\text { Latitude corresponding to the centroid of } \\
\text { the stage of the Reconquest }\end{array}$} & & $0.031^{* *}$ & & $0.032 *$ \\
\hline & & $(0.014)$ & & $(0.015)$ \\
\hline \multirow[t]{2}{*}{ Constant } & $9.959^{* * *}$ & $8.672^{* * *}$ & $9.955^{* * *}$ & $8.63^{* * *}$ \\
\hline & $(0.041)$ & $(0.569)$ & $(0.046)$ & $(0.618)$ \\
\hline$R^{2}$ & 0.40 & 0.56 & 0.38 & 0.54 \\
\hline Number of observations & 17 & 17 & 16 & 16 \\
\hline
\end{tabular}




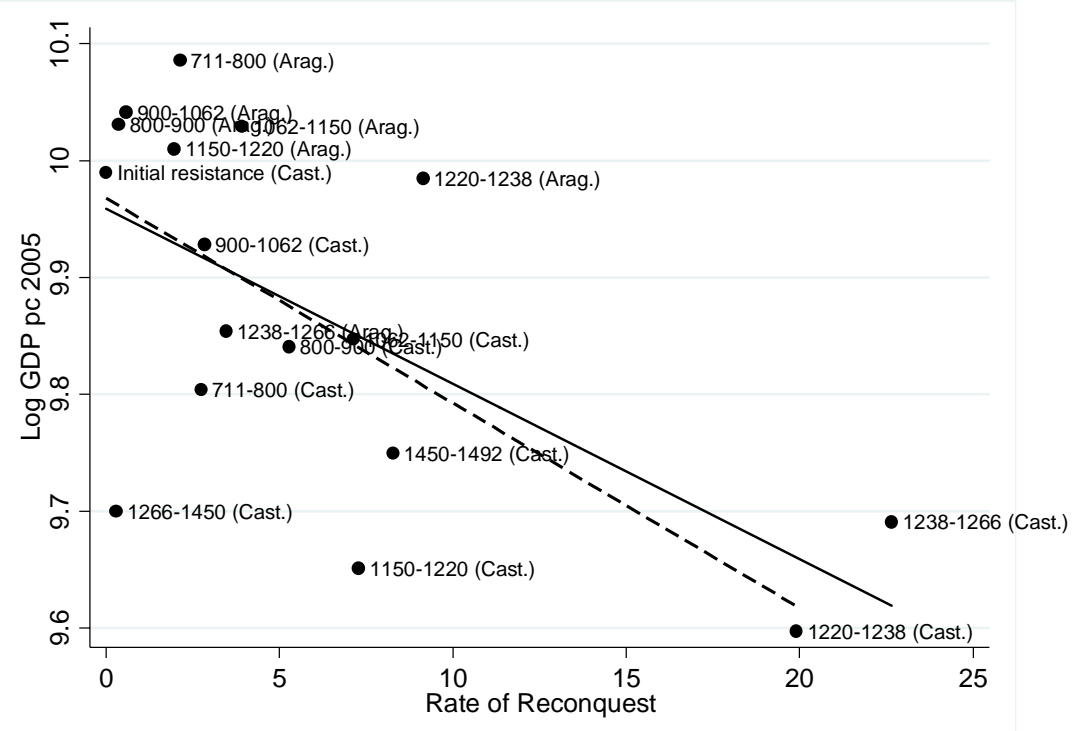

Panel A: Comparing the slope of the regression line when removing areas conquered between 1220 and 1266 in Castile.

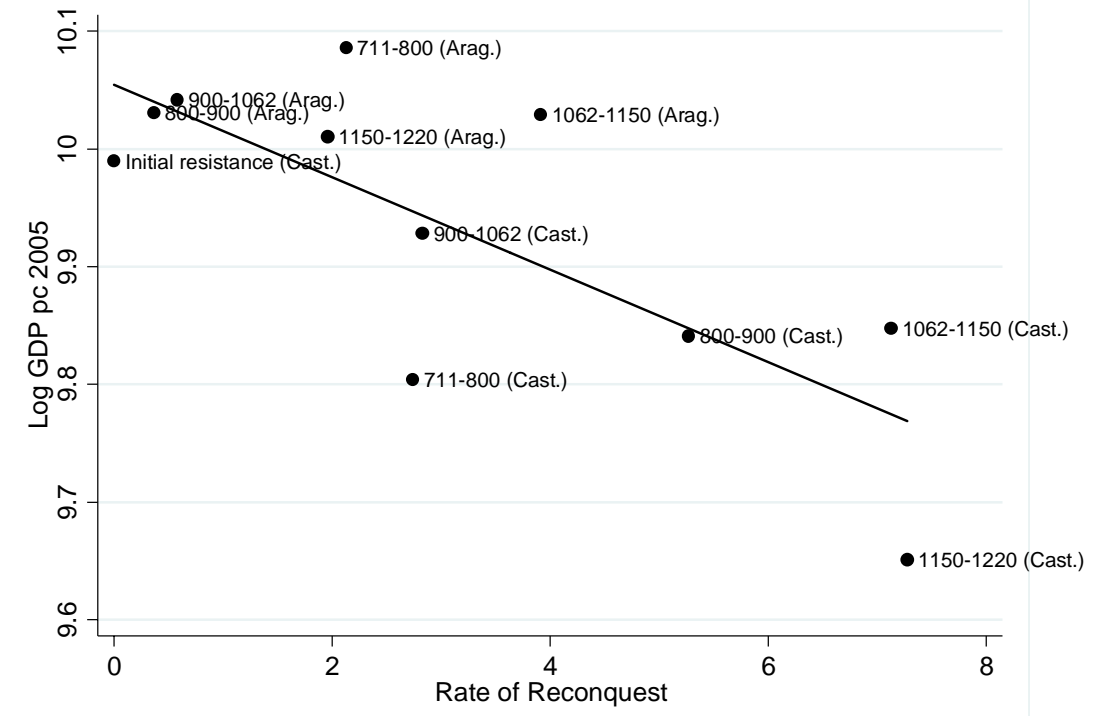

Panel B: Removing areas conquered after 1220 in Castile and Aragon

Figure A2. Relationship between current GDP per capita and rate of Reconquest: Aggregating provinciallevel data at the stage of Reconquest level: Robustness checks

Notes:

The $y$-axis variable is the logarithm of the weighted average of output per capita in 2005 for the territory corresponding to each Reconquest stage, using provincial surface area in each stage as weights.

Note that the 1266-1450 Reconquest stage in Castile is a clear outlier caused by the stability of the frontier of Granada over an extended period of time. 
Appendix I. Exploiting variation across the stages of the Reconquest: Aggregating municipality-level data at the stage of Reconquest level.

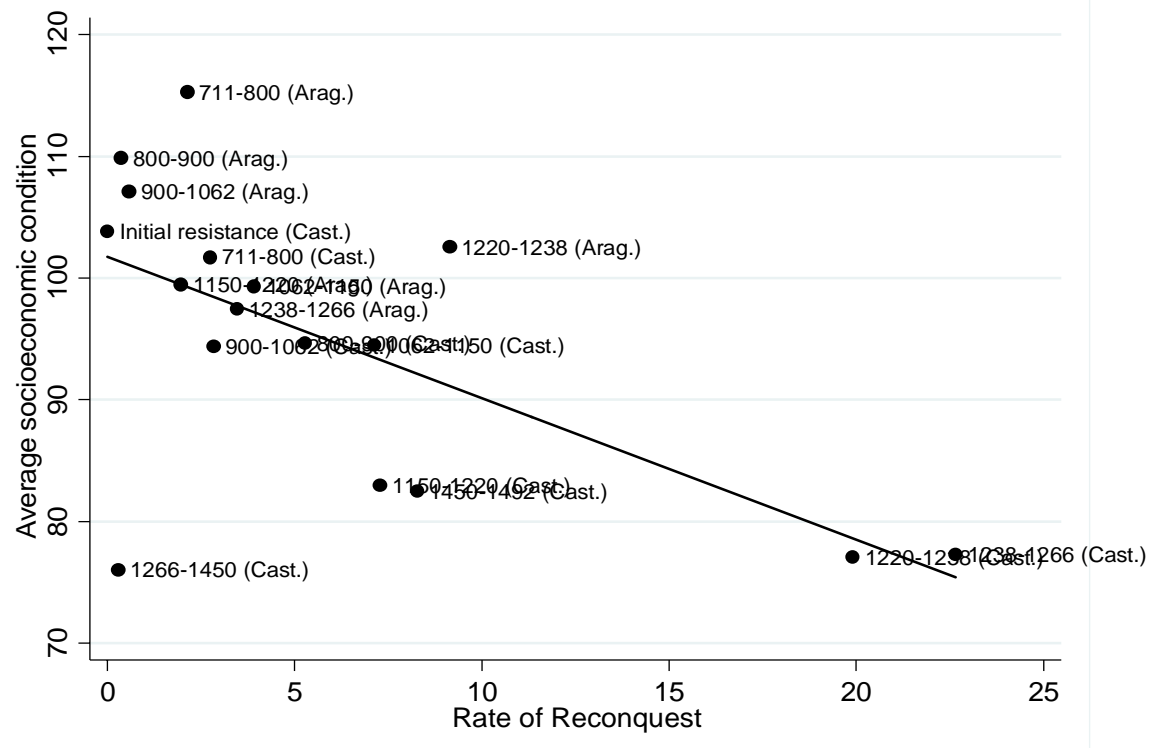

Figure A3. Relationship between average socioeconomic condition and rate of Reconquest: Aggregating municipality-level data at the stage of Reconquest level.

Notes:

The $y$-axis variable reflects the average value of the indicator for the municipalities located within each stage of the Reconquest.

Note that the 1266-1450 Reconquest stage in Castile is a clear outlier caused by the stability of the frontier of Granada over an extended period of time. 


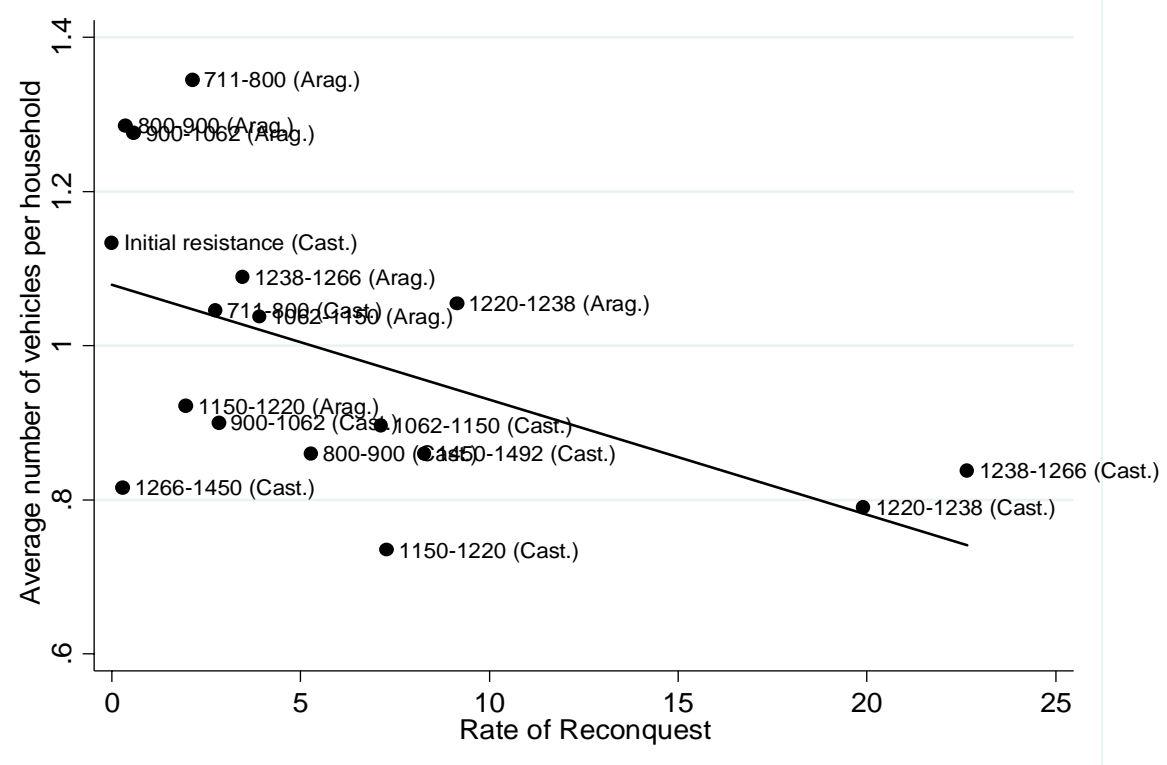

Figure A4. Relationship between average number of vehicles per household and rate of Reconquest: Aggregating municipality-level data at the stage of Reconquest level.

Notes:

The $y$-axis variable reflects the average value of the indicator for the municipalities located within each stage of the Reconquest.

Note that the 1266-1450 Reconquest stage in Castile is a clear outlier caused by the stability of the frontier of Granada over an extended period of time.

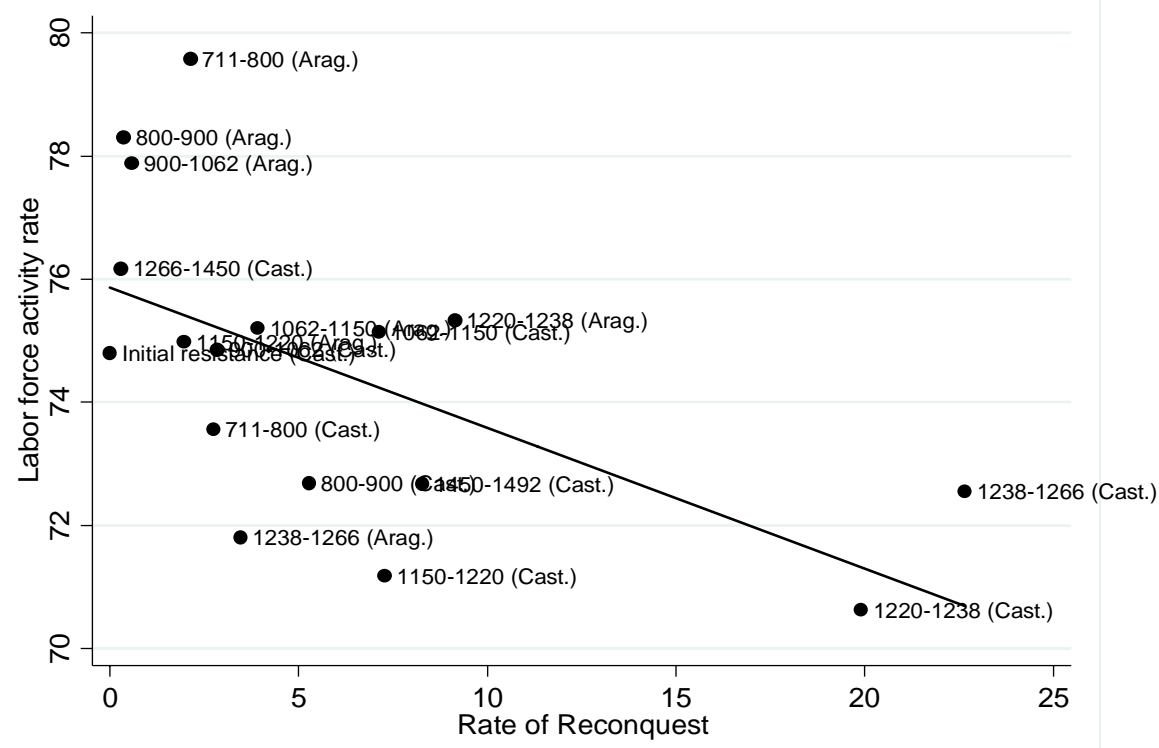

Figure A5. Relationship between labor force activity rate and rate of Reconquest: Aggregating municipality-level data at the stage of Reconquest level.

Notes:

The y-axis variable reflects the average value of the indicator for the municipalities located within each stage of the Reconquest. 


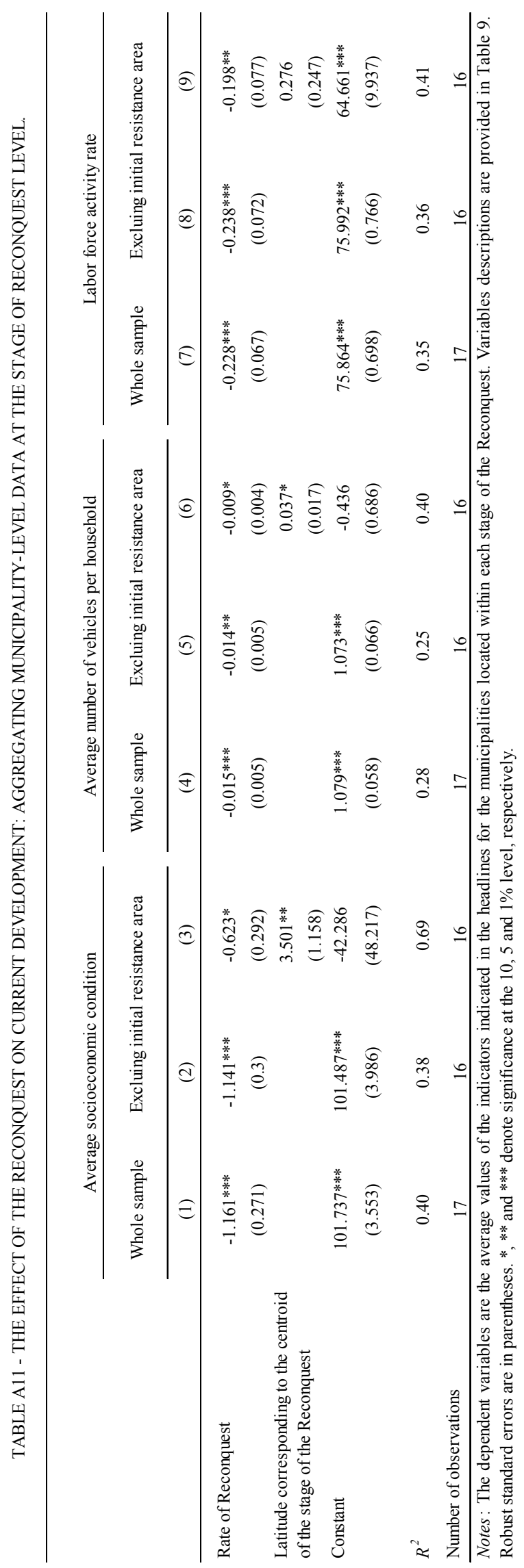


TABLE A12 - NORTH-SOUTH GRADIENT: WITHIN 'STAGE OF RECONQUEST' VARIATION IN LATITUDE

\begin{tabular}{lccc}
\hline & $\begin{array}{c}\text { Average } \\
\text { socioeconomic } \\
\text { condition }\end{array}$ & $\begin{array}{c}\text { Average number of } \\
\text { vehicles per } \\
\text { household }\end{array}$ & $\begin{array}{c}\text { Labor force activity } \\
\text { rate }\end{array}$ \\
\hline Latitude & 1.463 & -0.005 & $(3)$ \\
\hline Constant & $(1.988)$ & $(0.022)$ & 0.585 \\
& 21.914 & 0.987 & $5.661)$ \\
Reconquest stages dummies & $(73.5)$ & $(0.821)$ & $(24.443)$ \\
R-squared & Yes & Yes & Yes \\
Number of obs & 0.40 & 0.30 & 0.10 \\
\hline
\end{tabular}

Notes: Variables descriptions are provided in Table 9. Standard errors clustered at the stage of Reconquest level are in parentheses. *,** and *** denote significance at the 10,5 and $1 \%$ level, respectively. 
Appendix J. Municipality-level analysis correcting SEs for spatial dependence and clustering SEs at the province level.

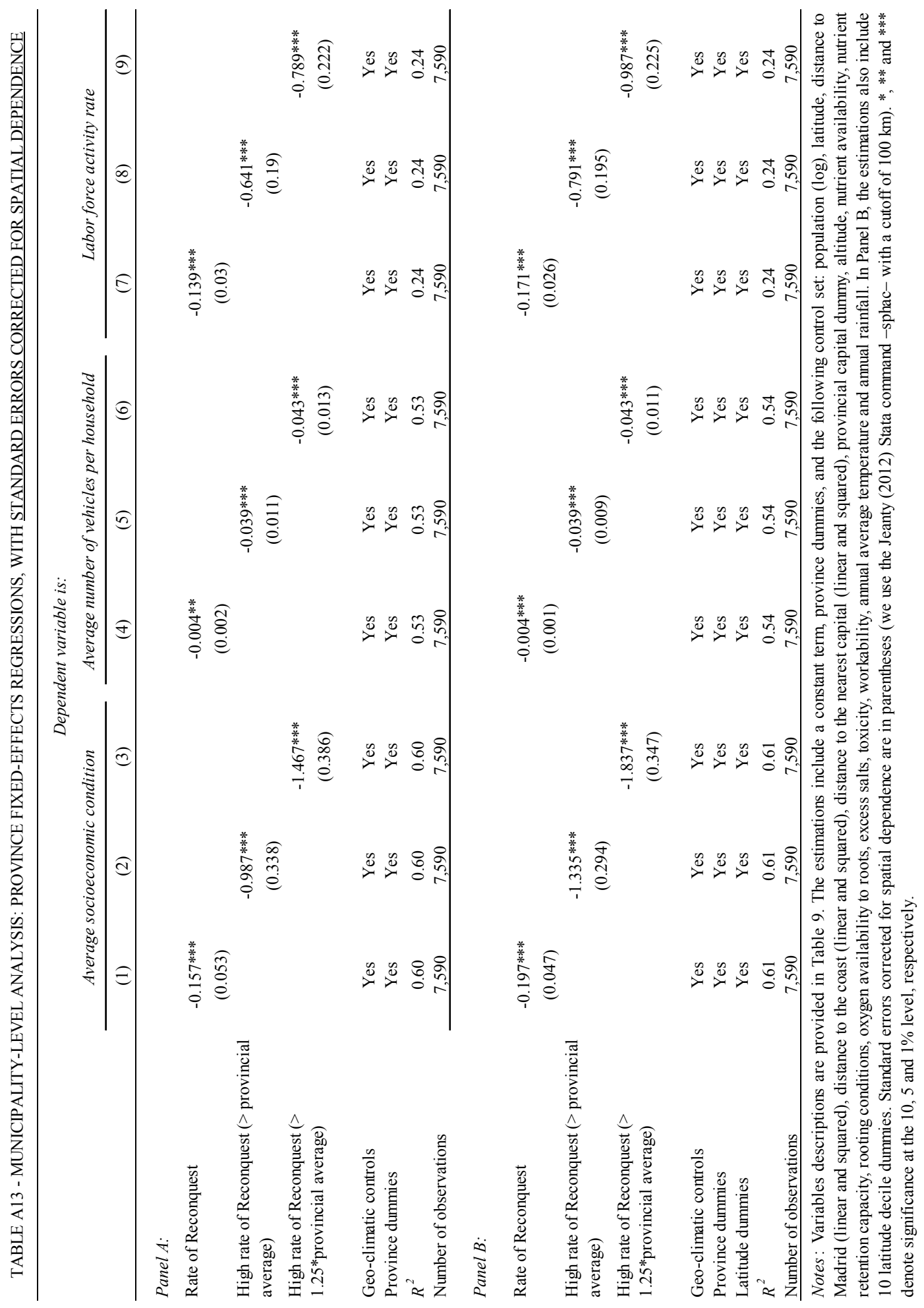




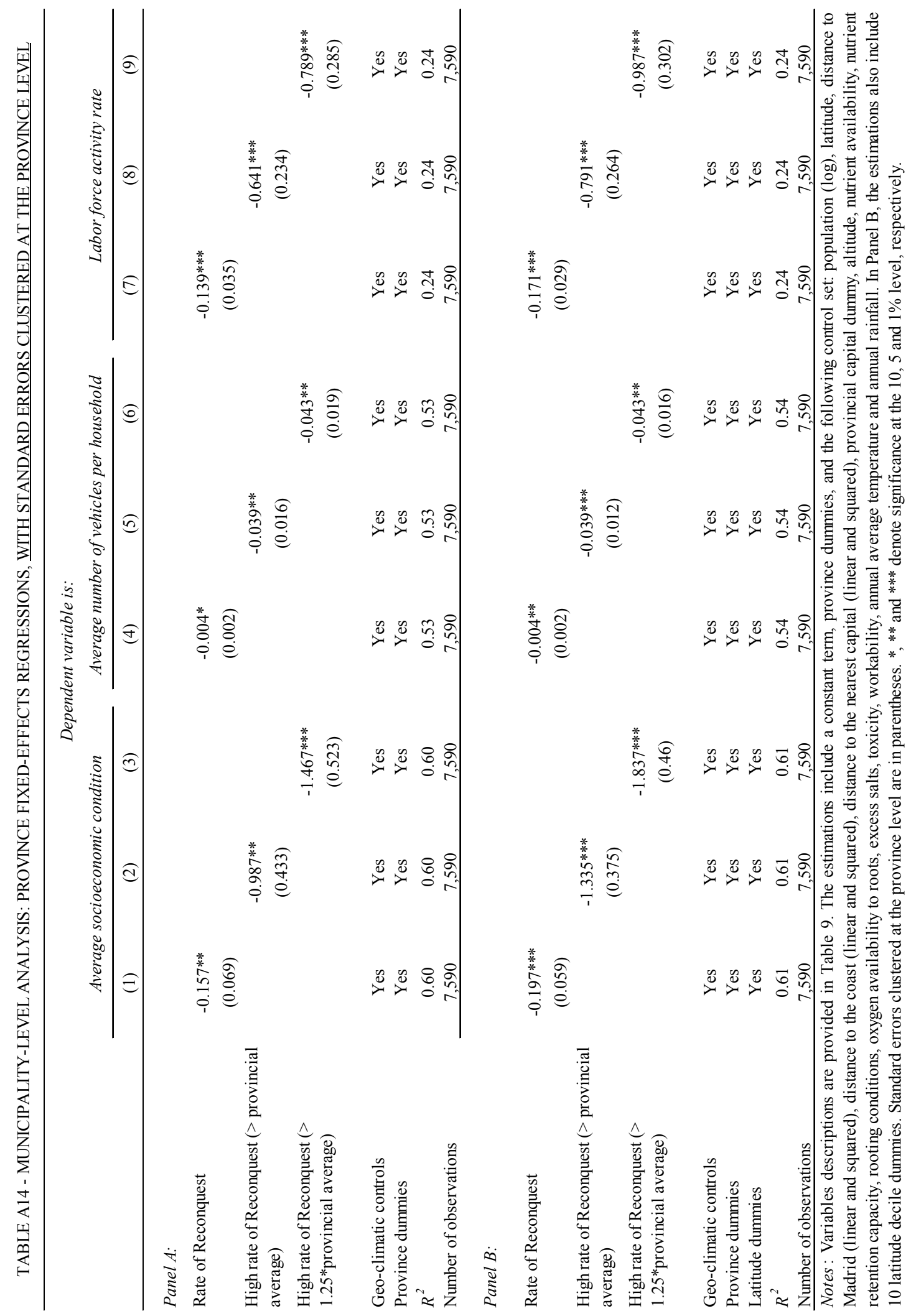




\section{Appendix K. Correlations between indicators of pre-Reconquest development and suitability for agriculture.}

TABLE A15. CORRELATIONS BETWEEN INDICATORS OF PRE-RECONQUEST DEVELOPMENT AND SUITABILITY FOR AGRICULTURE

\begin{tabular}{|c|c|c|}
\hline & $\begin{array}{c}\text { Agricultural land } 1900 \\
\text { (\%) }\end{array}$ & Arable land $1962(\%)$ \\
\hline \multirow[t]{2}{*}{ City population in 800} & $0.2642 *$ & $0.2749^{*}$ \\
\hline & 0.0696 & 0.0533 \\
\hline \multirow[t]{2}{*}{ Density of urban population in 800} & $0.2817^{*}$ & $0.2707 *$ \\
\hline & 0.0524 & 0.0573 \\
\hline \multirow[t]{2}{*}{ Years since transition to agriculture } & -0.0129 & -0.1147 \\
\hline & 0.9308 & 0.4275 \\
\hline \multirow[t]{2}{*}{ Ancient settlements over surface area } & 0.1488 & 0.0628 \\
\hline & 0.3127 & 0.6646 \\
\hline \multirow[t]{2}{*}{ Roman roads density: Main roads } & $0.2941 * *$ & $0.3915 * * *$ \\
\hline & 0.0425 & 0.0049 \\
\hline \multirow[t]{2}{*}{ Roman roads density } & $0.2356^{+}$ & $0.3676^{* * *}$ \\
\hline & 0.107 & 0.0086 \\
\hline \multirow[t]{2}{*}{ Coinage of imperial Roman coins over surface area } & $0.2478^{*}$ & 0.2091 \\
\hline & 0.0895 & 0.145 \\
\hline \multirow[t]{2}{*}{ Roman villas over surface area } & $0.3869 * * *$ & $0.3010 * *$ \\
\hline & 0.0066 & 0.0337 \\
\hline \multirow[t]{2}{*}{ Number of bishoprics circa 600 over surface area } & 0.1589 & 0.1763 \\
\hline & 0.2808 & 0.2206 \\
\hline
\end{tabular}

Notes: Variables descriptions are provided in Table 9. For each entry we provide the correlation coefficient (above) and the p-value (below). ${ }^{+}, * * *$ and $* * *$ denote significance at the $11,10,5$ and $1 \%$ level, respectively. 
Appendix L. 2SLS regressions using soil quality as an instrument. 


\begin{tabular}{|c|c|c|c|}
\hline \multirow{4}{*}{ 2SLS framework $\rightarrow$} & \multicolumn{3}{|c|}{ Dependent variable is log GDP per capita in 2005} \\
\hline & \multirow{2}{*}{$\begin{array}{c}\text { Our theory (Specification } \\
\text { used in Table } 6, \text { column } 1 \text { ) } \\
\begin{array}{c}\text { Reconquest rate } \rightarrow \text { Landless } \\
\text { workers } 1797 \rightarrow \text { Current } \\
\text { income } \\
\text { Soil quality enters as an } \\
\text { exogenous regressor }\end{array}\end{array}$} & \multicolumn{2}{|c|}{ Falsification test: soil quality as an instrument } \\
\hline & & $\begin{array}{c}\text { Soil quality } \rightarrow \\
\text { Landless workers } 1797 \rightarrow \\
\text { Current income }\end{array}$ & $\begin{array}{c}\text { Soil quality } \rightarrow \\
\text { Landless workers } 1797 \rightarrow \\
\quad \text { Current income } \\
\text { Reconquest rate enters as an } \\
\text { exogenous regressor }\end{array}$ \\
\hline & (1) & (2) & (3) \\
\hline \multicolumn{4}{|l|}{ Panel A: Second stage } \\
\hline Percentage of landless workers in 1797 & $\begin{array}{c}-0.009^{* * *} \\
(0.003)\end{array}$ & $\begin{array}{c}0.01 \\
(0.008)\end{array}$ & $\begin{array}{c}0.019 \\
(0.014)\end{array}$ \\
\hline Soil quality & $\begin{array}{c}0.601 * * * \\
(0.194)\end{array}$ & & \\
\hline Rate of reconquest & & & $\begin{array}{l}-0.048^{*} \\
(0.027)\end{array}$ \\
\hline Crown of Aragon & $\begin{array}{c}0.042 \\
(0.094)\end{array}$ & $\begin{array}{c}0.141 \\
(0.128)\end{array}$ & $\begin{array}{l}-0.176 \\
(0.238)\end{array}$ \\
\hline Madrid & $\begin{array}{c}0.525^{* * *} \\
(0.04)\end{array}$ & $\begin{array}{c}0.269^{*} \\
(0.14)\end{array}$ & $\begin{array}{c}0.129 \\
(0.222)\end{array}$ \\
\hline Rainfall & $\begin{array}{l}0,000 \\
(0.00)\end{array}$ & $\begin{array}{l}0,000 \\
(0.00)\end{array}$ & $\begin{array}{l}0,000 \\
(0.00)\end{array}$ \\
\hline Ruggedness & $\begin{array}{l}0.226^{*} \\
(0.125)\end{array}$ & $\begin{array}{l}0.003 \\
(0.22)\end{array}$ & $\begin{array}{c}0.361 \\
(0.305)\end{array}$ \\
\hline Mediterranean Sea & $\begin{array}{c}0.026 \\
(0.072)\end{array}$ & $\begin{array}{l}-0.074 \\
(0.106)\end{array}$ & $\begin{array}{l}-0.144 \\
(0.145)\end{array}$ \\
\hline Cantabrian Sea & $\begin{array}{c}-0.071 \\
(0.067)\end{array}$ & $\begin{array}{l}0.073 \\
(0.15)\end{array}$ & $\begin{array}{c}0.227 \\
(0.236)\end{array}$ \\
\hline Border with Portugal & $\begin{array}{c}-0.082 \\
(0.066)\end{array}$ & $\begin{array}{l}-0.077 \\
(0.093)\end{array}$ & $\begin{array}{c}0.131 \\
(0.181)\end{array}$ \\
\hline Ln distance from Paris & $\begin{array}{l}-0.185 \\
(0.12)\end{array}$ & $\begin{array}{l}-0.565 \\
(0.398)\end{array}$ & $\begin{array}{c}-0.8 \\
(0.48)\end{array}$ \\
\hline Coal dummy in 1860 & $\begin{array}{l}0.092^{*} \\
(0.053) \\
\end{array}$ & $\begin{array}{c}-0.008 \\
(0.135) \\
\end{array}$ & $\begin{array}{l}-0.025 \\
(0.141) \\
\end{array}$ \\
\hline \multicolumn{4}{|l|}{ Panel B: First stage } \\
\hline Rate of Reconquest & $\begin{array}{c}1.683 * * * \\
(0.402)\end{array}$ & & $\begin{array}{c}1.683 * * * \\
(0.402)\end{array}$ \\
\hline Soil quality & $\begin{array}{c}21.273 \\
(13.876)\end{array}$ & $\begin{array}{l}31.312 * \\
(16.049)\end{array}$ & $\begin{array}{c}21.273 \\
(13.876)\end{array}$ \\
\hline Crown of Aragon & $\begin{array}{c}7.706 \\
(8.036)\end{array}$ & $\begin{array}{c}-5.171 \\
(8.319)\end{array}$ & $\begin{array}{c}7.706 \\
(8.036)\end{array}$ \\
\hline Madrid & $\begin{array}{c}14.001 * * * \\
(2.925)\end{array}$ & $\begin{array}{c}13.333 * * * \\
(3.526)\end{array}$ & $\begin{array}{c}14.001 * * * \\
(2.925)\end{array}$ \\
\hline Rainfall & $\begin{array}{c}0,000 \\
(0.015)\end{array}$ & $\begin{array}{c}-0.017 \\
(0.014)\end{array}$ & $\begin{array}{c}0,000 \\
(0.015)\end{array}$ \\
\hline Ruggedness & $\begin{array}{c}-4.78 \\
(12.855)\end{array}$ & $\begin{array}{c}11.641 \\
(13.572)\end{array}$ & $\begin{array}{c}-4.78 \\
(12.855)\end{array}$ \\
\hline Mediterranean Sea & $\begin{array}{c}6.003 \\
(6.345)\end{array}$ & $\begin{array}{c}5.209 \\
(6.668)\end{array}$ & $\begin{array}{c}6.003 \\
(6.345)\end{array}$ \\
\hline Cantabrian Sea & $\begin{array}{c}-10.557^{*} \\
(5.749)\end{array}$ & $\begin{array}{c}-7.515 \\
(7.888)\end{array}$ & $\begin{array}{c}-10.557^{*} \\
(5.749)\end{array}$ \\
\hline Border with Portugal & $\begin{array}{c}-7.561 \\
(5.158)\end{array}$ & $\begin{array}{c}-0.274 \\
(6.356)\end{array}$ & $\begin{array}{l}-7.561 \\
(5.158)\end{array}$ \\
\hline Ln distance from Paris & $21.746^{*}$ & 19.788 & $21.746^{*}$ \\
\hline Coal dummy in 1860 & $\begin{array}{c}(12.314) \\
4.121 \\
(5.174)\end{array}$ & $\begin{array}{c}(17.551) \\
5.196 \\
(6.847)\end{array}$ & $\begin{array}{c}(12.314) \\
4.121 \\
(5.174)\end{array}$ \\
\hline$R^{2}$ & 0,7 & 0,56 & 0,7 \\
\hline Number of observations & 45 & 45 & 45 \\
\hline
\end{tabular}




\section{Appendix M. The timing of the effect of the Reconquest: Regression results.}

TABLE A17 - THE TIMING OF THE EFFECT OF THE RECONQUEST: REGRESSION RESULTS (II)

\begin{tabular}{|c|c|c|c|c|c|c|c|}
\hline \multicolumn{8}{|c|}{ Dependent variable is relative GDP per capita } \\
\hline & (1) & (2) & (3) & (4) & (5) & (6) & (7) \\
\hline Rate of Reconquest x 1930 & $\begin{array}{c}-1.932 * * \\
(0.743)\end{array}$ & $\begin{array}{c}-1.587 * * \\
(0.757)\end{array}$ & $\begin{array}{c}-1.761 * * \\
(0.743)\end{array}$ & $\begin{array}{c}-1.953 * * * \\
(0.713)\end{array}$ & $\begin{array}{c}-1.907 * * \\
(0.741)\end{array}$ & $\begin{array}{l}-1.171 \\
(0.836)\end{array}$ & $\begin{array}{l}-1.134 \\
(0.916)\end{array}$ \\
\hline Rate of Reconquest x 1971 & $\begin{array}{c}-2.655^{* * *} \\
(0.695)\end{array}$ & $\begin{array}{c}-2.33^{* * * *} \\
(0.691)\end{array}$ & $\begin{array}{c}-2.526^{* * *} \\
(0.691)\end{array}$ & $\begin{array}{c}-2.676^{* * *} \\
(0.657)\end{array}$ & $\begin{array}{c}-2.665^{* * *} \\
(0.714)\end{array}$ & $\begin{array}{c}-2.192 * * \\
(0.872)\end{array}$ & $\begin{array}{l}-2.23 * * \\
(0.924)\end{array}$ \\
\hline Rate of Reconquest x 2005 & $\begin{array}{c}-2.806^{* * *} \\
(0.737)\end{array}$ & $\begin{array}{c}-2.377 * * * \\
(0.738)\end{array}$ & $\begin{array}{c}-2.631 * * * \\
(0.733)\end{array}$ & $\begin{array}{c}-2.823 * * * \\
(0.711)\end{array}$ & $\begin{array}{c}-2.84 * * * \\
(0.76)\end{array}$ & $\begin{array}{c}-2.252^{* *} \\
(0.868)\end{array}$ & $\begin{array}{c}-2.209^{* *} \\
(0.937)\end{array}$ \\
\hline Soil quality x 1930 & & $\begin{array}{l}-33.795^{*} \\
(20.119)\end{array}$ & & & & & $\begin{array}{l}-15.895 \\
(20.55)\end{array}$ \\
\hline Soil quality x 1971 & & $\begin{array}{l}-31.815 \\
(21.243)\end{array}$ & & & & & $\begin{array}{l}-18.796 \\
(22.434)\end{array}$ \\
\hline Soil quality x 2005 & & $\begin{array}{c}-42.017 * * \\
(19.765)\end{array}$ & & & & & $\begin{array}{l}-20.536 \\
(20.116)\end{array}$ \\
\hline Cantabrian Sea x 1930 & & & $\begin{array}{c}54.476^{* * *} \\
(6.059)\end{array}$ & & & & $\begin{array}{c}54.663 * * * \\
(9.517)\end{array}$ \\
\hline Cantabrian Sea x 1971 & & & $\begin{array}{c}41.1^{* * * *} \\
(5.01)\end{array}$ & & & & $\begin{array}{c}35.776^{* * * *} \\
(11.01)\end{array}$ \\
\hline Cantabrian Sea x 2005 & & & $\begin{array}{c}55.437 * * * \\
(5.393)\end{array}$ & & & & $\begin{array}{c}45.849^{* * * *} \\
(9.566)\end{array}$ \\
\hline Coal dummy x 1930 & & & & $\begin{array}{c}19.876 \\
(12.684)\end{array}$ & & & $\begin{array}{c}17.822 \\
(11.847)\end{array}$ \\
\hline Coal dummy x 1971 & & & & $\begin{array}{c}19.409^{* *} \\
(8.777)\end{array}$ & & & $\begin{array}{l}19.23 * * \\
(8.768)\end{array}$ \\
\hline Coal dummy x 2005 & & & & $\begin{array}{l}16.367 \\
(10.75)\end{array}$ & & & $\begin{array}{l}15.482 \\
(9.852)\end{array}$ \\
\hline Medit. Sea x 1930 & & & & & $\begin{array}{l}11.559 \\
(14.1)\end{array}$ & & $\begin{array}{l}13.705 \\
(14.12)\end{array}$ \\
\hline Medit. Sea x 1971 & & & & & $\begin{array}{c}-4.393 \\
(13.084)\end{array}$ & & $\begin{array}{c}-2.405 \\
(13.308)\end{array}$ \\
\hline Medit. Sea x 2005 & & & & & $\begin{array}{l}-15.805 \\
(13.016)\end{array}$ & & $\begin{array}{l}-13.501 \\
(13.176)\end{array}$ \\
\hline Log distance to Paris $\mathrm{x} 1930$ & & & & & & $\begin{array}{l}-31.478 \\
(23.308)\end{array}$ & $\begin{array}{l}-18.778 \\
(24.494)\end{array}$ \\
\hline Log distance to Paris $\mathrm{x} 1971$ & & & & & & $\begin{array}{l}-19.162 \\
(25.214)\end{array}$ & $\begin{array}{c}-6.052 \\
(26.122)\end{array}$ \\
\hline Log distance to Paris $\mathrm{x} 2005$ & & & & & & $\begin{array}{l}-22.902 \\
(23.844)\end{array}$ & $\begin{array}{l}-11.935 \\
(24.534)\end{array}$ \\
\hline Time dummies & Yes & Yes & Yes & Yes & Yes & Yes & Yes \\
\hline Province dummies & Yes & Yes & Yes & Yes & Yes & Yes & Yes \\
\hline$R^{2}$ & 0.68 & 0.69 & 0.69 & 0.69 & 0.7 & 0.69 & 0.73 \\
\hline Number of observations & 180 & 180 & 180 & 180 & 180 & 180 & 180 \\
\hline
\end{tabular}

Notes: Panel specifications that regress each province's GDP per capita relative to the national average over the 1860-2005 period on the interaction between rate of Reconquest and time dummies, with data measured at 1860 , 1930, 1970 and 2005. Variables descriptions are provided in Table 9. The estimations include a constant term, which is omitted for space considerations. Robust standard errors are in parentheses. Small-sample correction for standard errors is applied. *, ** and $* * *$ denote significance at the 10,5 and $1 \%$ level, respectively. 


\begin{tabular}{|c|c|c|c|c|c|c|c|}
\hline \multicolumn{8}{|c|}{ Dependent variable is relative industrial output per capita } \\
\hline & (1) & (2) & (3) & (4) & (5) & (6) & (7) \\
\hline Rate of Reconquest x 1930 & $\begin{array}{c}-4.573 * * * \\
(1.125)\end{array}$ & $\begin{array}{c}-4.741 * * * \\
(1.235)\end{array}$ & $\begin{array}{c}-4.58 * * * \\
(1.158)\end{array}$ & $\begin{array}{c}-4.604 * * * \\
(1.16)\end{array}$ & $\begin{array}{c}-4.576^{* * *} \\
(1.151)\end{array}$ & $\begin{array}{c}-4.07 * * * \\
(1.296)\end{array}$ & $\begin{array}{c}-4.476^{* * * *} \\
(1.495)\end{array}$ \\
\hline Rate of Reconquest x 1971 & $\begin{array}{c}-5.856^{* * *} \\
(1.057)\end{array}$ & $\begin{array}{c}-5.774 * * * \\
(1.145)\end{array}$ & $\begin{array}{c}-5.809^{* * *} \\
(1.085)\end{array}$ & $\begin{array}{c}-5.855^{* * *} \\
(1.084)\end{array}$ & $\begin{array}{c}-5.928^{* * *} \\
(1.148)\end{array}$ & $\begin{array}{c}-4.84 * * * \\
(1.244)\end{array}$ & $\begin{array}{c}-4.802 * * * \\
(1.433)\end{array}$ \\
\hline Rate of Reconquest x 2005 & $\begin{array}{c}-6.397 * * * \\
(1.269)\end{array}$ & $\begin{array}{c}-6.098 * * * \\
(1.4)\end{array}$ & $\begin{array}{c}-6.281 * * * \\
(1.307)\end{array}$ & $\begin{array}{c}-6.396 * * * \\
(1.291)\end{array}$ & $\begin{array}{c}-6.537 * * * \\
(1.325)\end{array}$ & $\begin{array}{c}-4.766^{* * *} \\
(1.354)\end{array}$ & $\begin{array}{c}-4.655^{* * *} \\
(1.587)\end{array}$ \\
\hline Soil quality x 1930 & & $\begin{array}{c}16.414 \\
(25.964)\end{array}$ & & & & & $\begin{array}{c}27.5 \\
(33.383)\end{array}$ \\
\hline Soil quality x 1971 & & $\begin{array}{c}-8.046 \\
(22.931)\end{array}$ & & & & & $\begin{array}{c}29.844 \\
(32.922)\end{array}$ \\
\hline Soil quality x 2005 & & $\begin{array}{l}-29.307 \\
(27.254)\end{array}$ & & & & & $\begin{array}{c}34.772 \\
(35.054)\end{array}$ \\
\hline Cantabrian Sea x 1930 & & & $\begin{array}{c}-2,00 \\
(10.841)\end{array}$ & & & & $\begin{array}{c}14.354 \\
(14.509)\end{array}$ \\
\hline Cantabrian Sea x 1971 & & & $\begin{array}{l}15.057^{*} \\
(8.984)\end{array}$ & & & & $\begin{array}{c}17.835 \\
(15.207)\end{array}$ \\
\hline Cantabrian Sea x 2005 & & & $\begin{array}{c}36.884 * * * \\
(12.77)\end{array}$ & & & & $\begin{array}{l}33.09 * * \\
(15.982)\end{array}$ \\
\hline Coal dummy x 1930 & & & & $\begin{array}{c}29.069 \\
(22.081)\end{array}$ & & & $\begin{array}{c}26.849 \\
(19.716)\end{array}$ \\
\hline Coal dummy x 1971 & & & & $\begin{array}{c}-1.186 \\
(18.545)\end{array}$ & & & $\begin{array}{l}-10.426 \\
(17.647)\end{array}$ \\
\hline Coal dummy x 2005 & & & & $\begin{array}{c}-1.191 \\
(28.459)\end{array}$ & & & $\begin{array}{l}-15.326 \\
(24.361)\end{array}$ \\
\hline Medit. Sea x 1930 & & & & & $\begin{array}{c}-1.382 \\
(22.864)\end{array}$ & & $\begin{array}{l}-3.048 \\
(22.42)\end{array}$ \\
\hline Medit. Sea x 1971 & & & & & $\begin{array}{c}-33.491^{*} \\
(18.1)\end{array}$ & & $\begin{array}{c}-35.811 * * \\
(17.703)\end{array}$ \\
\hline Medit. Sea x 2005 & & & & & $\begin{array}{c}-64.902 * * * \\
(24.191)\end{array}$ & & $\begin{array}{c}-67.65^{* * *} \\
(23.486)\end{array}$ \\
\hline Log distance to Paris $x 1930$ & & & & & & $\begin{array}{c}-20.833 \\
(40.194)\end{array}$ & $\begin{array}{c}-15.23 \\
(36.888)\end{array}$ \\
\hline Log distance to Paris x 1971 & & & & & & $\begin{array}{l}-42.021 \\
(37.215)\end{array}$ & $\begin{array}{l}-56.616^{*} \\
(34.029)\end{array}$ \\
\hline Log distance to Paris $\mathrm{x} 2005$ & & & & & & $\begin{array}{c}-67.485 \\
(41.178)\end{array}$ & $\begin{array}{c}-87.796^{* *} \\
(36.628)\end{array}$ \\
\hline Time dummies & Yes & Yes & Yes & Yes & Yes & Yes & Yes \\
\hline Province dummies & Yes & Yes & Yes & Yes & Yes & Yes & Yes \\
\hline$R^{2}$ & 0,7 & 0,7 & 0,7 & 0,7 & 0,74 & 0,71 & 0,77 \\
\hline Number of observations & 180 & 180 & 180 & 180 & 180 & 180 & 180 \\
\hline
\end{tabular}


Appendix N. Correlations between GDP per capita 2005 and several proxies for economic development over time.

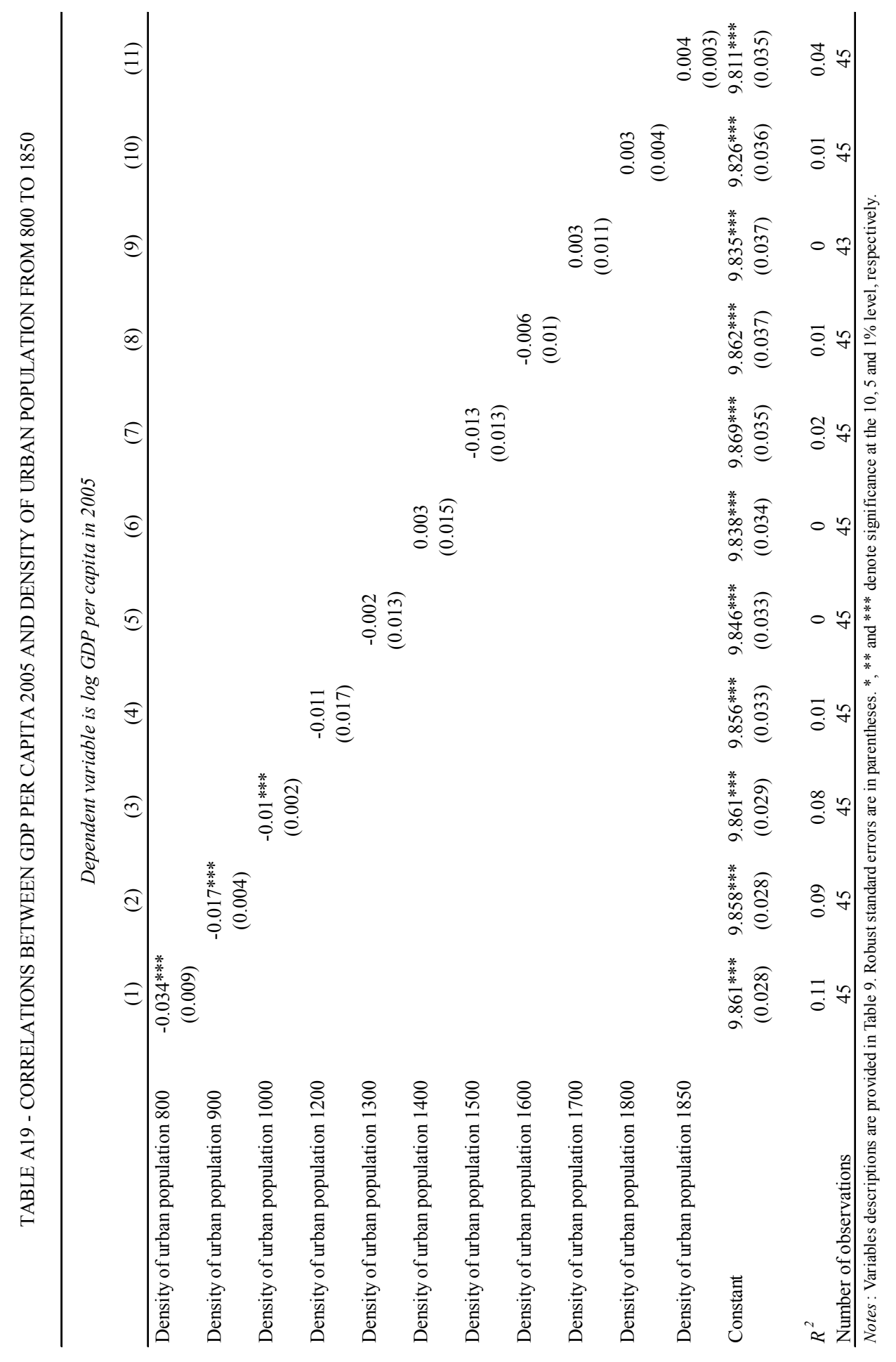


TABLE A20 - CORRELATIONS BETWEEN GDP PER CAPITA 2005 AND URBANIZATION RATE FROM 1600 TO 2001

Dependent variable is log GDP per capita in 2005

\begin{tabular}{|c|c|c|c|c|c|c|c|c|}
\hline & (1) & (2) & (3) & (4) & (5) & (6) & (7) & $(8)$ \\
\hline Urbanization rate circa 1600 & $\begin{array}{c}-0.002 \\
(0.001)\end{array}$ & & & & & & & \\
\hline Urbanization rate 1787 & & $\begin{array}{l}-0.002 \\
(0.001)\end{array}$ & & & & & & \\
\hline Urbanization rate 1860 & & & $\begin{array}{c}0.000 \\
(0.002)\end{array}$ & & & & & \\
\hline Urbanization rate 1900 & & & & $\begin{array}{c}0.000 \\
(0.002)\end{array}$ & & & & \\
\hline Urbanization rate 1930 & & & & & $\begin{array}{c}0.000 \\
(0.002)\end{array}$ & & & \\
\hline Urbanization rate 1960 & & & & & & $\begin{array}{c}0.001 \\
(0.002)\end{array}$ & & \\
\hline Urbanization rate 1981 & & & & & & & $\begin{array}{c}0.002 \\
(0.001)\end{array}$ & \\
\hline Urbanization rate 2001 & & & & & & & & $\begin{array}{c}0.002 \\
(0.002)\end{array}$ \\
\hline Constant & $\begin{array}{l}9.87 * * * \\
(0.037)\end{array}$ & $\begin{array}{c}9.895 * * * \\
(0.044)\end{array}$ & $\begin{array}{c}9.849 * * * \\
(0.04)\end{array}$ & $\begin{array}{c}9.846^{* * *} \\
(0.044)\end{array}$ & $\begin{array}{c}9.845^{* * *} \\
(0.047)\end{array}$ & $\begin{array}{c}9.806^{* * *} \\
(0.057)\end{array}$ & $\begin{array}{c}9.727^{* * *} \\
(0.08)\end{array}$ & $\begin{array}{l}9.74 * * * \\
(0.094)\end{array}$ \\
\hline$R^{2}$ & 0.03 & 0.03 & 0.00 & 0.00 & 0.00 & 0.01 & 0.04 & 0.02 \\
\hline Number of observations & 42 & 41 & 45 & 45 & 45 & 45 & 45 & 45 \\
\hline
\end{tabular}

Notes : Variables descriptions are provided in Table 9. Robust standard errors are in parentheses. ${ }^{*}, * *$ and $* * *$ denote significance at the 10,5 and $1 \%$ level, respectively. 
TABLE A21 - CORRELATIONS BETWEEN GDP PER CAPITA 2005 AND GDP PER CAPITA AND INDUSTRIAL OUTPUT PER CAPITA AT SEVERAL POINTS IN TIME

Dependent variable is log GDP per capita in 2005

\begin{tabular}{|c|c|c|c|c|c|c|c|}
\hline & (1) & (2) & (3) & (4) & (5) & (6) & (7) \\
\hline Log GDP per capita 1860 & $\begin{array}{c}0.102 \\
(0.063)\end{array}$ & & & & & & \\
\hline Log GDP per capita 1930 & & $\begin{array}{c}0.401 * * * \\
(0.056)\end{array}$ & & & & & \\
\hline Log GDP per capita 1971 & & & $\begin{array}{l}0.63 * * * \\
(0.047)\end{array}$ & & & & \\
\hline Log industrial output per capita 1860 & & & & $\begin{array}{c}0.042 \\
(0.048)\end{array}$ & & & \\
\hline Log industrial output per capita 1930 & & & & & $\begin{array}{c}0.188^{* * * *} \\
(0.03)\end{array}$ & & \\
\hline Log industrial output per capita 1970 & & & & & & $\begin{array}{c}0.271 * * * \\
(0.037)\end{array}$ & \\
\hline Log industrial output per capita 2005 & & & & & & & $\begin{array}{c}0.221 * * * \\
(0.041)\end{array}$ \\
\hline Constant & $\begin{array}{c}9.247^{* * *} \\
(0.359)\end{array}$ & $\begin{array}{c}7.021 * * * \\
(0.393)\end{array}$ & $\begin{array}{c}1.542^{* *} \\
(0.62)\end{array}$ & $\begin{array}{c}9.671^{* * *} \\
(0.188)\end{array}$ & $\begin{array}{c}8.839 * * * \\
(0.158)\end{array}$ & $\begin{array}{c}7.229 * * * \\
(0.362)\end{array}$ & $\begin{array}{c}8.102 * * * \\
(0 . .328)\end{array}$ \\
\hline R-squared & 0.04 & 0.43 & 0.74 & 0.02 & 0.4 & 0.53 & 0.40 \\
\hline Number of obs & 45 & 45 & 45 & 45 & 45 & 45 & 45 \\
\hline
\end{tabular}

Notes : Variables descriptions are provided in Table 9. Robust standard errors are in parentheses. *, ** and *** denote significance at the 10,5 and $1 \%$ level, respectively. 


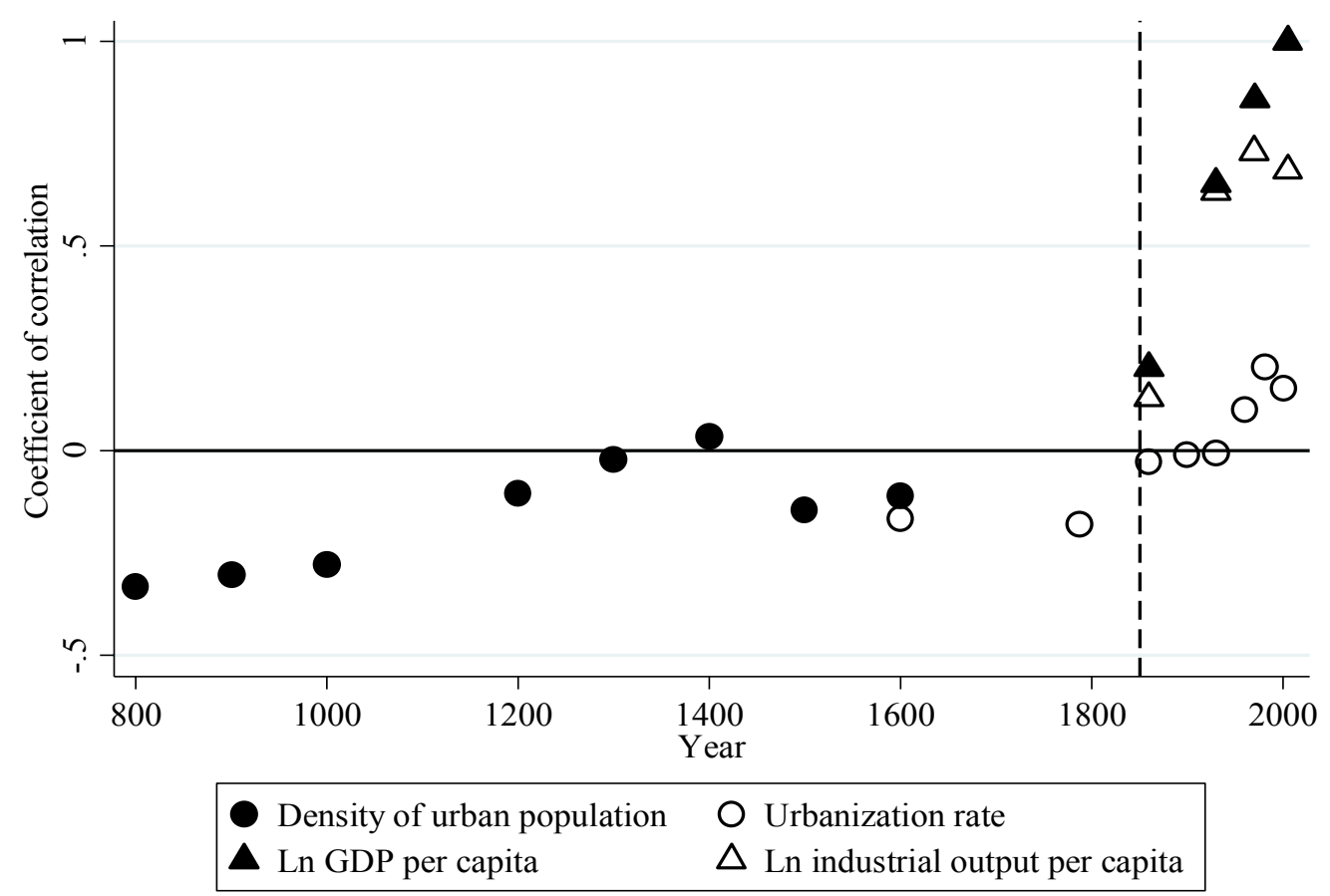

Figure A6. Values of the coefficients of correlation between log GDP per capita in 2005 and several proxies for economic development measured from 800 to 2005 
TABLE A22 - COEFFICIENTS OF CORRELATION AT SEVERAL POINTS IN TIME BETWEEN LN GDP PER CAPITA AND I) URBANIZATION RATE OR II) LN INDUSTRIAL OUTPUT PER CAPITA

\begin{tabular}{|c|c|c|c|c|c|}
\hline & & \multicolumn{4}{|c|}{ Ln GDP per capita } \\
\hline & & 1860 & 1930 & 1971 & 2005 \\
\hline \multirow{4}{*}{ Urbanization rate } & 1860 & 0.6426 & & & \\
\hline & 1930 & & 0.5431 & & \\
\hline & 1960 & & & 0.3453 & \\
\hline & 2001 & & & & 0.1534 \\
\hline \multirow{4}{*}{ Ln Industrial output per capita } & 1860 & 0.7367 & & & \\
\hline & 1930 & & 0.8062 & & \\
\hline & 1970 & & & 0.8297 & \\
\hline & 2005 & & & & 0.6354 \\
\hline
\end{tabular}




\section{Appendix O. Taking into account that the exact timing of industrialization may be endogenous.}

The above results in Appendix $\mathrm{N}$ suggest that the Reconquest is clearly linked to industrialization. We pursue this question further by taking into account that the exact timing of industrialization in Spain may be endogenous. Thus, we complement the previous analysis with some panel regressions formerly used by AJR (2002, p. 1274-5), which use industrialization in the UK as a proxy for the opportunity to industrialize. For the sake of robustness, we also consider industrialization in the US as an alternative to the British, using in both cases data from Mitchell (2007a, b). The panel data specification is as follows:

$$
y_{i t}=\alpha_{i}+\theta_{t}+\delta \text { Reconquest }_{i} x \text { Industrialization }_{t}+v_{i t}
$$

where $y_{i t}$ is either provincial GDP per capita or industrial output per capita expressed in relative terms with respect to the national average at date $t(1860,1930,1971$, and 2005). $\alpha_{i}$ is a set of province-level dummies and $\theta_{t}$ stands for a set of time dummies. Reconquest $_{i}$ represents the rate of Reconquest in province $i$ and Industrialization denotes either UK industrial output or US industrial output at date $t$, as alternative measures of the opportunity to industrialize. The coefficient of interest is $\delta$ on the interaction between rate of Reconquest and industrialization, which should be negative and statistically significant. This would imply that the negative effect of the rate of Reconquest becomes more pervasive when the opportunity to industrialize arrived. Table A25 presents the panel regressions for the cases in which the dependent variable is relative GDP per capita and relative industrial output per capita. It is worth stressing that the interaction term $\delta$ appears negative and statistically significant at the $1 \%$ level in all cases, which is consistent with the results reported in Appendix N. In sum, all these results suggest that the adverse effect of the Reconquest on income occurred mainly during industrialization, and has persisted since then. The remainder of the paper sets out to explain these findings.

\section{References}

Acemoglu, Daron, Simon Johnson, and James A. Robinson. 2002. "Reversal of Fortune: Geography and Institutions in the Making of the Modern World Income Distribution." Quarterly Journal of Economics 117 (4): 1231-1294.

Mitchell, Brian R. 2007a. International Historical Statistics. Europe, 1750-2005. Palgrave: Hampshire. 
Mitchell, Brian R. 2007b. International Historical Statistics. The Americas, 1750-2005. Palgrave: Hampshire.

TABLE A23 - THE TIMING OF THE EFFECT OF THE RECONQUEST: PANEL RESULTS

\begin{tabular}{|c|c|c|c|c|}
\hline & \multicolumn{2}{|c|}{$\begin{array}{c}\text { Dependent variable is relative GDP } \\
\text { per capita (average }=100 \text { ) }\end{array}$} & \multicolumn{2}{|c|}{$\begin{array}{c}\text { Dependent variable is relative } \\
\text { industrial output per capita } \\
\text { (average }=100)\end{array}$} \\
\hline & (1) & (2) & (3) & (4) \\
\hline $\begin{array}{l}\text { Rate of Reconquest * UK industrial } \\
\text { output }\end{array}$ & $\begin{array}{l}-0.01 * * * \\
(0.003)\end{array}$ & & $\begin{array}{l}-0.023^{* * *} \\
(0.005)\end{array}$ & \\
\hline $\begin{array}{l}\text { Rate of Reconquest * US industrial } \\
\text { output }\end{array}$ & & $\begin{array}{c}-0.002^{* * *} \\
(0)\end{array}$ & & $\begin{array}{c}-0.004 * * * \\
(0.001)\end{array}$ \\
\hline Time dummies & Yes & Yes & Yes & Yes \\
\hline Province dummies & Yes & Yes & Yes & Yes \\
\hline$R^{2}$ & 0.67 & 0.66 & 0.68 & 0.67 \\
\hline Number of observations & 180 & 180 & 180 & 180 \\
\hline
\end{tabular}




\section{Appendix P. Implications of land inequality.}

In a society like preindustrial Spain where agriculture was by far the most important economic activity, having access to a key factor of production such as land was decisive for social inequality and economic development. Not surprisingly, the highly unequal land distribution in the South was considered a first-order problem, which led throughout modern Spanish history to intense debates about the "agrarian question". The enlightenment reformers of the eighteenth century pointed to unequal landownership as a main factor behind Spanish agrarian and economic backwardness. Regarding the implications for social inequality, Pablo de Olavide (1768), Intendent of Seville in the second half of the eighteenth century, described the social structure of Andalusia (in southern Spain) as divided into four classes. First, the smaller class of owners, who rarely cultivate their lands but they rather lease them. Second, the class of large tenants, many of whom sublet land divided into smaller plots. Third, the class of small tenants, who, in addition to paying high rents, cannot properly cultivate the land because leases were granted for such short periods that each year they were in danger of losing their holdings. Finally, the fourth class, the crowd, is composed mostly of landless workers. In Olavide's words, they are:

"the unhappiest men that I know in Europe. They exercise to go to work to farmhouses or olive yards, but they can only go when they are called by the administrator of the farmhouse, that is, in the proper times for work. Then, despite being almost clothless and always sleeping on the floor, at least they can live on the bread and gazpacho they are given. But when the dead time arrives, that in which one cannot work outdoor due to for instance lack of rain or when the fields are left fallow for the rest of the year, these men die of starvation, they have neither shelter nor hope, and they are obliged to go begging [...] These men are half-a-year laborers, and the other half beggars" (authors' translation).

This class of landless laborers, which can be traced back to the fifteenth century, ${ }^{1}$ was the consequence of the concentration of land in the hands of the nobility and military

\footnotetext{
${ }^{1}$ According to Cabrera (1989) "From the 1460s onwards the existence of a large rural proletariat [in the Guadalquivir Valley] can be clearly documented. Indeed, use of the notarial records alone would suggest
} 
orders. They were mainly located in the Spanish regions conquered relatively fast. The 1797 population census reflects that landless workers represented about three quarters of the agricultural labor force in those regions conquered by Castile since the thirteenth century (i.e., the territories where the privileged orders received a large number of land grants), while the situation was completely different in regions conquered earlier (Malefakis 1970). This situation was condemning the mass of the agricultural population to a very low standard of living and a chronic situation of seasonal unemployment (Pascual and Sudriá 2002). In addition, they suffered the abuses of landowners who controlled town councils and promoted regulations in favor of their interests such as price caps on daily wages and severe punishment for property crimes (Dominguez-Ortiz 1955). This picture, far from disappearing, lasted until well into the twentieth century. ${ }^{2}$ High social inequality generated by the unequal land distribution led to severe social tensions and conflicts, always characterized by a deep hunger for land. Thus, the "agrarian question" can be considered as a major historical problem in Spain and its lack of solution as the most important single cause of the Civil War in 19361939 (Brenan 1943).

Regarding the implications for economic development, high land concentration had negative consequences for agriculture productivity as highlighted by enlightenment thinkers of the eighteenth century (e.g., Olavide 1768; Jovellanos 1795). ${ }^{3}$ However, the fundamental implications for regional income distribution emerged when Spain entered into the industrial revolution in the second half of the nineteenth century. Until this period, the higher land fertility of many of the large estates regions was sufficient to make them stand among the richest in Spain. For example, still in 1860, at the beginning of the industrialization period, Andalusia was the second wealthiest region,

that those who actually worked the land were never, or hardly ever, the owners of it, the owners in effect being rentiers" (p. 480).

${ }^{2}$ Referring to the first half of the twentieth century, Brenan (1943) observes that "lower Andalusia is probably the only region in Europe where the condition of the agricultural workers has not improved in the last a hundred and fifty years" (p. 122).

3 It was due, for instance, to absentee landlords that were little concerned with improving farming techniques, concentration of rural population in a few towns, lack of incentives of small tenants and landless workers who cultivate the land, inefficiency in cultivating large estates, insufficient reinvestment of rents and profits as well as insecurity and poor conditions of the labor force (Carrión 1975; Malefakis 1970). 
ahead of Catalonia and the Basque Country, with a level of per capita GDP about 36 percentage points above the Spanish average. But seventy years later, in 1930, Andalusia was among the poorest regions, with a level of per capita GDP of only 77 percent of the Spanish average (data from Rosés et al. 2010). As argued in the main text, this occurred because of the failure to industrialize in the southern region of Spain, which was largely caused by the concentration of land in a few hands. Structural inequality prevented a broad-based participation of the population in economic activity, blocking industrialization and hindering the prospects for economic development.

\section{References}

Brenan, Geral. 1943. The Spanish Labyrinth: An Account of the Social and Political Background of the Spanish Civil War. Cambridge: Cambridge University Press.

Cabrera, Emilio. 1989. "The medieval Origins of the Great Landed Estates of the Guadalquivir Valley”. Economic History Review 42 (4): 465-483.

Carrión, Pascual. 1975. Los Latifundios en España. Su importancia, Origen. Consecuencias y Solución. Barcelona: Ariel.

Domínguez-Ortiz, Antonio. 1955. La Sociedad Española en el Siglo XVIII. Madrid: Consejo Superior de Investigaciones Científicas, Instituto Balmes de Sociología.

Jovellanos, Gaspar M. de. 1795. Escritos Económicos -Gaspar Melchor de Jovellanos. Informe sobre la Ley Agraria. Madrid: Real Academia de Ciencias Morales y Políticas, D.L. 2000.

Malefakis, Edward. 1970. Agrarian Reform and Peasant Revolution in Spain. Origins of the Civil War. New Haven: Yale University Press.

Olavide, Pablo de. 1768. Informe sobre la Ley Agraria. In La Reforma Agraria en Andalucía: el Primer Proyecto Legislativo, edited by Merchán, Antonio. Sevilla: Universidad de Sevilla, 1996.

Pascual, Pere, and Sudriá, Carles. 2002. "El Difícil Arranque de la Industrialización.” In Historia económica de España: Siglos X-XX, edited by Comín, Francisco, Mauro Hernández y Enrique Llopis, Chapter 6, 203-241. Barcelona: Crítica, D.L.

Rosés, Joan R., Julio Martínez-Galarraga, and Daniel A. Tirado. 2010. "The upswing of regional income inequality in Spain (1860-1930)". Explorations in Economic History 47: $244-257$. 


\section{Appendix Q. A case study of our theory applied to the development paths of Seville vs. Barcelona.}

The purpose of this Appendix is to show how our theory explains the different development paths of a province in Andalusia like Seville, whose Reconquest was fast (2194 km²/year), versus Barcelona with a much slower Reconquest rate (158 km²/year). For the reasons given above, the repopulation of Barcelona rendered a much more equal distribution of land and lordships (as given by a percentage of landless workers of $55.93 \%$ and a percentage of population entities under noble jurisdiction of $51 \%$ ) versus the more unequal distribution in Seville (with a percentage of landless workers of $85.60 \%$ and a percentage of population entities under noble jurisdiction of $73.53 \%$ ). Over time, in large estates regions like Seville, a land tenure system based on short-term leases and a policy of oppressing the broad mass of the landless peasantry (which highly reduced wages) prevailed. In contrast, in those regions like Barcelona, characterized by small and medium-size landholdings owned by free and independent families, a more stable form of leasing that could be passed across generations (rabassa morta) predominated. In the latter case, there was a much higher incentive to introduce improvements in agricultural technology and the benefits of the agrarian activity could be shared more equitably between those that owned the land and those that did not. Hence, family farms provided financial resources and entrepreneurial training that would be highly valuable when the opportunity to industrialize arrived. As pointed out by Carreras (1990) and Maluquer de Motes (1984), the higher revenues from the land and their more equal distribution created a demand for manufactured goods and led to the accumulation of capital, both factors being necessary for the emergence of an industrial sector (first the cotton and then the metallurgical industry were leading sectors in nineteenth century Barcelona). Thus, an equal distribution of the land and a prosperous market-oriented agriculture brought demographic vitality (and an abundant labor supply freed from agriculture) and capital accumulation which, combined with a flourishing entrepreneurial spirit propelled by a modern bourgeoisie, favored the establishment of a modern industrial sector and a regime of balanced growth in agriculture, industry and commerce (Tortellá, 2000). 
In contrast, in large estates provinces like Seville, land was highly concentrated and the broad mass of the population was formed by impoverished landless workers who lacked the human capital, financial resources and entrepreneurial training obtained from previously owning a farm. Under these circumstances, capital did not accumulate and the agricultural sector could not provide a strong market for industrial goods (Tortellá, 2000). If to this we add the fact that the landowning nobility, even at the end of the eighteenth century, considered "the practice of working in industry or commerce to seem incompatible with the condition with being a noble" (Sarrailh, 1957, p. 890), it is not surprising the well-known fact of southern Spain's failure to industrialize in the nineteenth century (Tedde de Lorca, 1985). As a result of this, southern Spain specialized in agricultural activities, with very low wages and high profits to the landlords. Over the course of the nineteenth century it would fall behind relative to other regions like Catalonia and the Basque Country that took advantage of the opportunity to industrialize. This accords with the fact that when economic and political power is distributed more equitably in society, the resulting economic institutions will tend to benefit the majority of the population and will be more appropriate for long-run growth (AJR, 2002).

To conclude, our analysis suggests that the pattern of land distribution can affect the transition from an agricultural to an industrial regime. One could also simplify the above arguments by pointing out that the transition from small agricultural enterprises (family farms) to industrial enterprises is much easier than from a situation of no farm (that of landless families) to an industrial enterprise.

\section{References}

Acemoglu, Daron, Simon Johnson, and James A. Robinson. 2002. "Reversal of Fortune: Geography and Institutions in the Making of the Modern World Income Distribution." Quarterly Journal of Economics 117 (4): 1231-1294.

Carreras, Albert. 1990. Cataluña, Primera Región Industrial de España, en Pautas Regionales de la Industrialización Española (Siglos XIX y XX), edited by Jordi Nadal and Albert Carreras, pp. 259-288, Ariel: Barcelona.

Maluquer de Motes, Jordi. (1984). La Revolución Industrial in Cataluña, L'Avenç, 73, 18-34. 
Sarrailh, Jean. 1957. La España Ilustrada de la Segunda Mitad del Siglo XVIII. Fondo de Cultura Económica, México.

Tedde de Lorca, Pedro. 1985. Sobre los Orígenes Históricos del Desarrollo Andaluz: Algunas Hipótesis, en La Modernización Económica de España, 1830-1930, edited by Nicolás Sánchez Albornoz, pp. 299-318, Alianza Editorial, Madrid.

Tortellá, Gabriel. 2000. The Development of Modern Spain. An Economic History of the Nineteenth and Twentieth Centuries. Harvard University Press, Cambridge: MA. 


\section{Appendix R. Channel analysis with two alternative measures of land concentration, and on the persistence of land inequality over time}

TABLE A24 - MECHANISMS AT WORK: LAND INEQUALITY

The channel variable $\rightarrow$ Land Gini Index in 1972

Land concentration in 1962

(1)

(2)

Panel A: Second stage (Log GDP pc 2005 regressed on the predicted values of the channel variable)

The channel variable (standardized)
$-0.018^{* * *}$
$-0.011 * * *$
$(0.006)$
(0.003)

Geo-climatic controls

Yes

Panel B: First stage (The channel variable regressed on rate of Reconquest)

Rate of Reconquest

$0.852 * * *$

(0.197)

0.35

18.7123

Partial $R^{2}$

\section{Yes}

0.71

45

$1.362 * * *$

(0.307)

0.39

Geo-climatic controls

$R^{2}$

Number of observations

19.6105

Panel C: OLS regressions of Log GDP pc 2005 on the channel variable

The channel variable (standardized)

$$
-0.009^{* * *}
$$

Geo-climatic controls

$R^{2}$

Yes

(0.002)

Number of observations
45
Yes

0.75

Yes

0.65

45

45

Notes: Variables descriptions are provided in Table 9. All the estimations include the control set employed in the baseline specification (column 1, Table 2) and a constant term, which are omitted for space considerations. Robust standard errors are in parentheses. Small-sample correction for standard errors is applied in 2SLS regressions. *, ** and $* * *$ denote significance at the 10,5 and $1 \%$ level, respectively. 


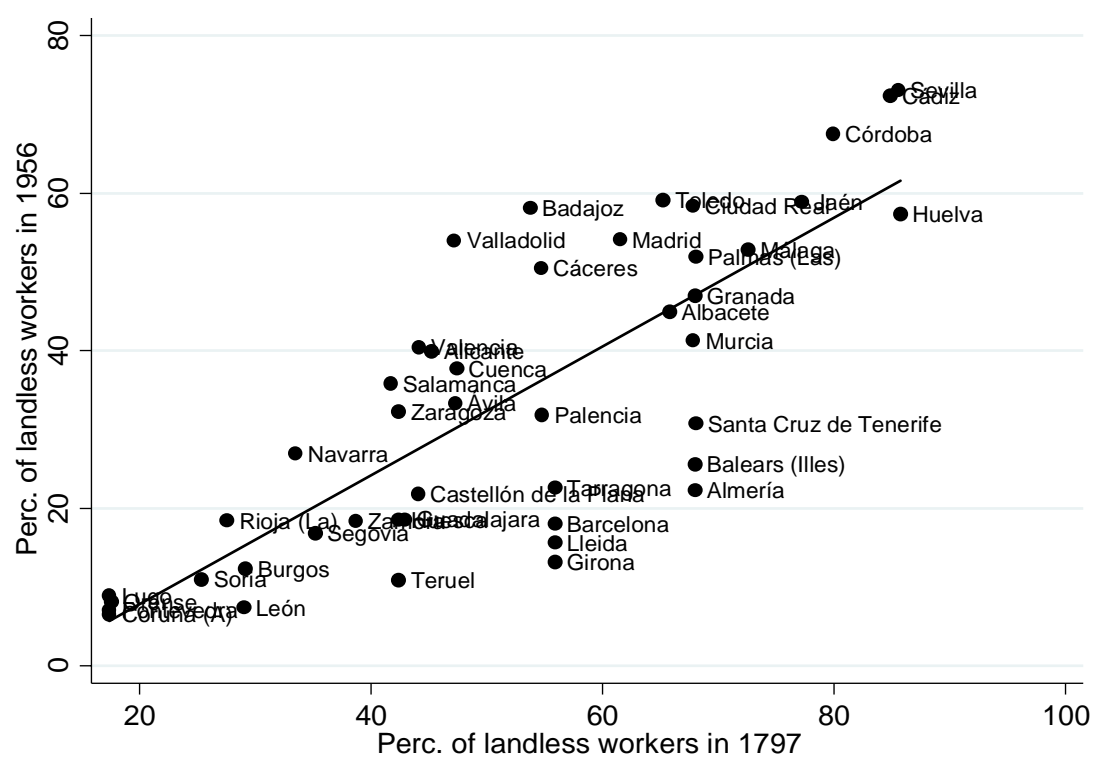

A) Bivariate relationship

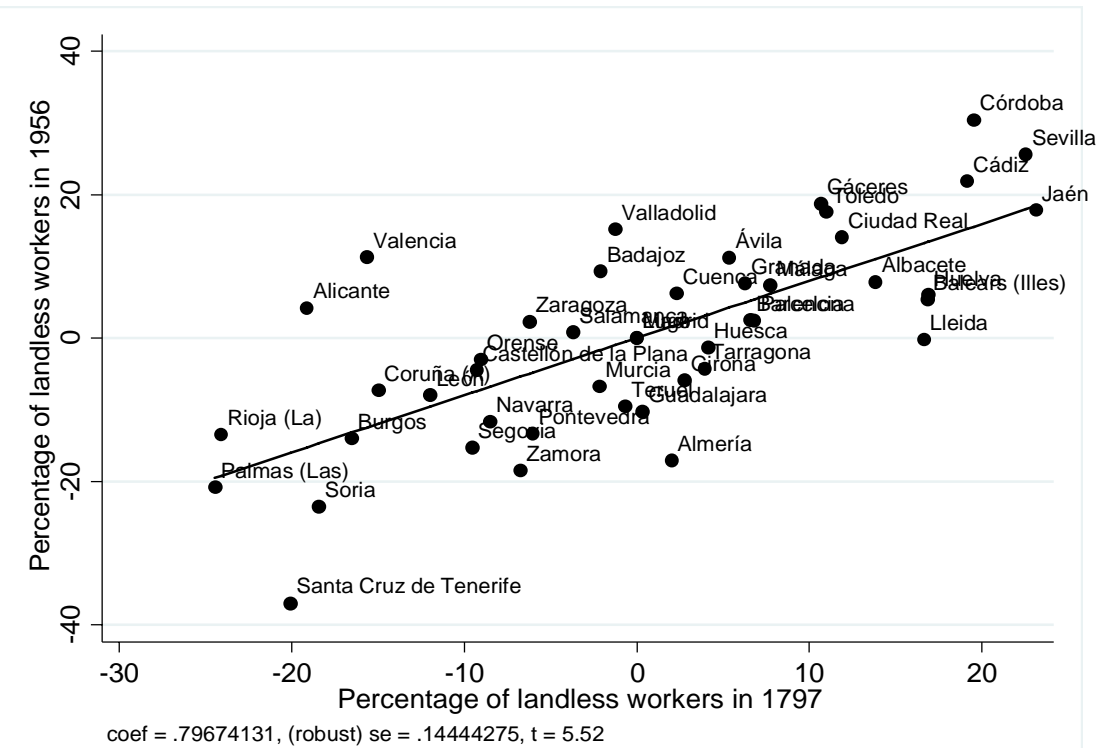
coef $=.79674131$, (robust) se $=.14444275, t=5.52$

B) Conditional relationship (after controlling for the set of controls used in column 1, Table 2)

Figure A7. The persistence of land inequality over time: the relationship between the percentage of landless workers in 1956 and 1797 
Appendix S. Current income distribution in the Spanish provinces.

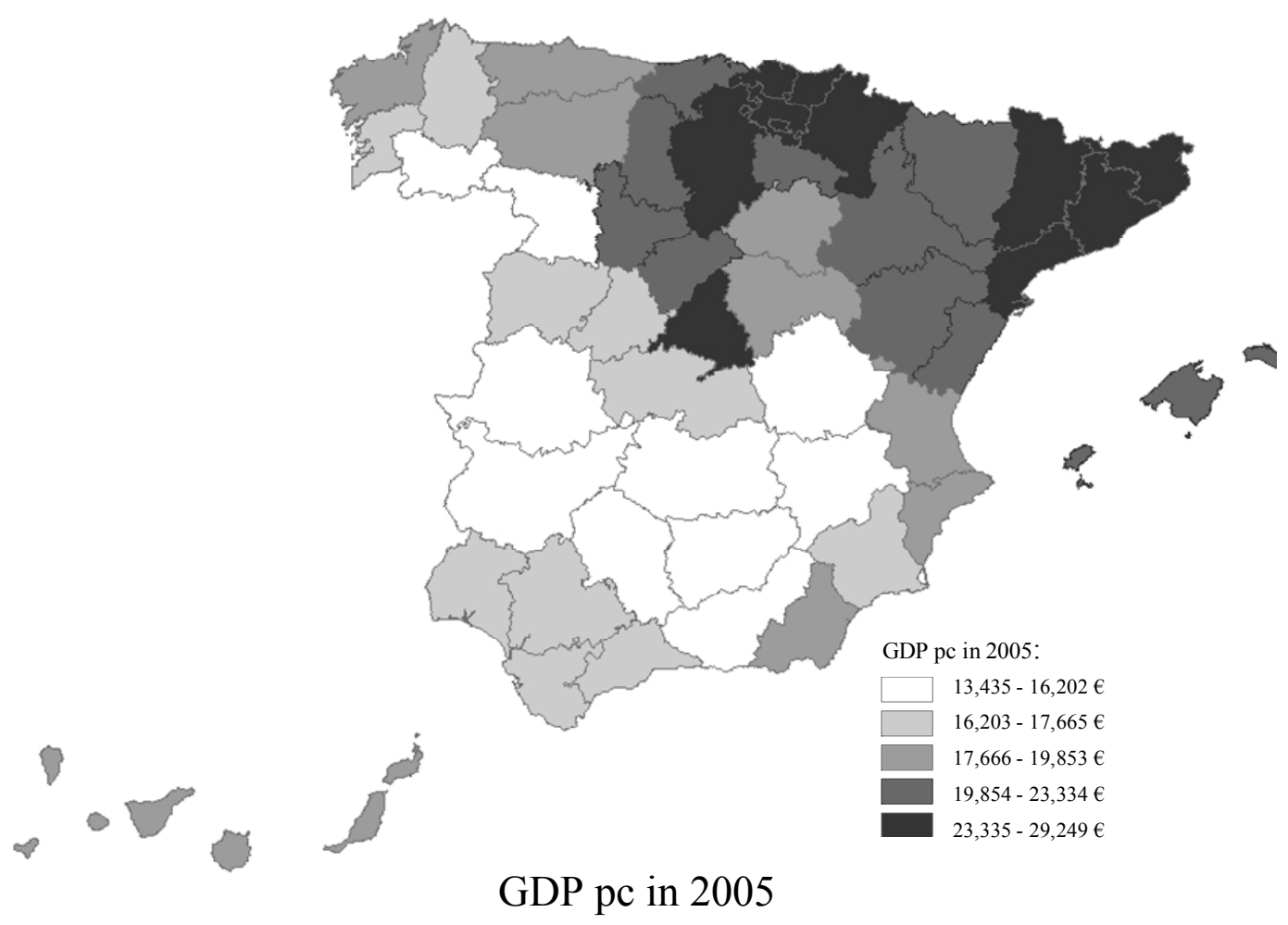

Figure A8. Current income distribution in the Spanish provinces 